\title{
THEORETICAL AND PRACTICAL ISSUES OF ENSURING THE ECONOMIC INTERESTS OF THE MODERN INNOVATIVE SOCIETY
}

$3^{\text {rd }}$ edition 


\section{THEORETICAL AND PRACTICAL ISSUES OF ENSURING THE ECONOMIC INTERESTS OF THE MODERN INNOVATIVE SOCIETY}

$3^{\text {rd }}$ edition

Research articles 


\title{
B\&M Publishing
}

Research and Publishing Center "Colloquium"

\section{THEORETICAL AND PRACTICAL ISSUES OF ENSURING THE ECONOMIC INTERESTS OF THE MODERN INNOVATIVE SOCIETY}

\author{
Science editor: R. Draut
}

Copyright (C) 2017

by Research and Publishing

Center "Colloquium"
ISBN 978-1-941655-55-9

DOI: http://doi.org/10.15350/L_3/3

All rights reserved.

Published by B\&M Publishing.

San Francisco, California 


\section{CONTENTS}

\section{ECONOMICS}

Capital outflow as the threat to economic safery the national economy

O. Safonova

Animation - the important element of perspective development

of rural tourism in regions of Uzbekistan

M. Alimova, Sh. Rakhmonov

The problems associated with import substitution in the agricultural sector of

the region by the example Orenburg region

M. Grinevich, D. Filatova

Innovation marketing and its importance

A. Ergashev

The importance of youth tourism

M. Khusenova

Analysis of factors determining the efficiency of import transactions

implemented by a company under economic uncertainty

O. Martyanova

Control submechanism of mechanism of energy saving management

in the system of higher education institutions

O. Shevchenko

Possibilities of increasing economic potential of industrial enterprises of

Uzbekistan (on the example of JSC «UZBEKLIGHTINDUSTRY»)

B. Usmanov

Approximation to european union environmental legislation: evolutionary

and revolutionary approaches for Ukraine

A. Kraskovska

Development of infrastructure logistic aspects

N. Ivanova

Theoretical approaches to the development of the productive forces of

Ukraine regions in the modernization dimension

O. Popelo

Theoretical aspects of formation and development of financialisation of regional economic systems

o. Treytyak

Organizational forms of innovation activity

o. Shevchenko

Chinese renminbi internationalization and possible effects for Hong Kong

stock exchange market

V. Biryukov, M. Zhiyenbayev

The problems of legalization of parallel imports in Russia

A. Salnikova

The problem of interactive visualizations of disciplines for primary schools

V. Saburov, A. Brezhnev

Approaches for risk analysis of the organization according to ISO 9001:2015 98

S. Kreneva, G. Tsareva, Ya. Yurchenko

Medical tourism resources in Kakheti on the example of Akhtala

G. Mamulashvili, T. Tamarashvili

Surveillance of irrigation associations in the Republic of Bulgaria manifestation of the state policy in the irrigation sector

V. Yordanov Velkovsky 


\title{
ECONOMICS
}

\section{CAPITAL OUTFLOW AS THE THREAT TO ECONOMIC SAFERY THE NATIONAL ECONOMY}

\section{O. Safonova ${ }^{1}$}

\begin{abstract}
In Russia the tendency of capital outflow increase has been formed and is developing now. Capital outflow appears and progresses in the countries, where there are essential problems with legislative and financial spheres of state management. It's a result these problems determine the investment climate of the country. The problem of capital outflow remains important up to now. Capital outflow threatens stability of economic system of Russia.

Results. The reasons of capital outflow from Russian Federation the analysis of its consequences are given. The ways of solving this problem were discovered and justified: necessity of justified conditions for the formation of favorable investment climate which will stimulate both Russian and foreign investors activities.

Conclusions. Illegal capital outflow from Russia is a phenomenon, which has a large economic effect, influencing stability and safety of Russian economy. To return capital to Russia, it is necessary, first of all, to create legislative conditions. But this is a very time consuming process of favourable investment climate formation, which stimulates both foreign and domestic investors activities.
\end{abstract}

Keywords: capital, capital outflow, offshore companies, deoffshorization, investment climate, shady transactions, currency market, financial market, stock market, shadow economy, exchange value of ruble, current account balance.

Отток капитала имеет существенное влияние на экономику России, так как средства, которые могли быть направлены на стимулирование развития российской экономики, уходят заграницу, тем самым ослабляют национальную экономическую систему и укрепляют иностранные экономики [1]. По данным Центрального банка Российской Федерации, чистый отток капитала из страны за последние 20 лет составил 624,5 млрд долларов [2].

После обострения геополитической ситуации во 2-й половине 2014 года многие компании предпочли вывести свои активы с российского рынка, чтобы свести к минимуму риски, связанные с инвестициями в экономику. Нестабильный курс рубля, проведение жесткой денежно-кредитной политики повлияли на интересы инвесторов, так как компании были заинтересованы в стабильной экономической ситуации [3].

${ }^{1}$ Olga Safonova, Candidate of Economical Science, an Associate Professor, of the State Public Institution «Lenin State Energy University of Ivanovo town», Russia. 
На отток капитала влияет нестабильность национальной валюты. Курс рубля напрямую влияет на доходы отечественных предприятий, и компании стараются сберечь свой капитал путём вложения в иностранные экономики.

К оттоку капитала из российской экономики приводит и изменение структуры вкладов населения - с рублей в валюту по статьям платежного баланса. За последние годы абсолютная сумма вложений российских граждан в валютные и другие инструменты увеличилась.

Одной из причин оттока капитала за рубеж также может выступать и рост теневой экономики. В современной России сформировалась неэффективная система государственного управления на федеральном и региональном уровнях. В стране до сих пор существует значительный сегмент теневой экономики и запредельный уровень коррупции в государственном и корпоративном секторах. По оценкам экспертов Банка России, общий объем теневой экономики в России в 2015 году оценивался примерно в 43-46\% ВВП, а в 2016 г. 39,07\% ВВП [4].

Кроме того, в России существует проблема, связанная с переводом капиталов в оффшоры. Данная проблема является одной из главных причин оттока капитала из России. Предприниматели, чтобы избежать налогообложения своих доходов и потерь их значительной части, переводят капиталы в оффшоры. По оценкам экспертов, 30-35 млрд долларов в год "утекают", маскируясь под расчеты за импортные товары, услуги, покупку финансовых активов у нерезидентов [5].

В России предпринимаются шаги по деоффшоризации российской экономики. В качестве одной из мер деоффшоризации Россия предлагает заключать двусторонние соглашения с оффшорными и низконалоговыми юрисдикциями. Согласно последнему отчету международной исследовательской организации Tax Justice Network (TJN), занимающейся независимыми расследованиями в области уклонений от уплаты налогов, на банковских счетах оффшорных юрисдикций находится от 21 до 32 триллионов долларов [6]. За 2015-2016 года из России в офшоры было выведено 1600 млрд рублей (почти 25 млрд долларов), в том числе в 2015 году 700 млрд. рублей (11,4 млрд. долларов) и в 2016 году - 900 млрд. рублей (13,5 млрд. долларов). Удельный вес офшорных юрисдикций в официальном оттоке капитала из России в 2015 году составлял 20\%, в 2016 году $87 \%[6]$.

Ещё одним фактором увеличение оттока капитала из российской экономики является увеличение операций, производимых на валютном рынке, и объёмов сделок с производными ценными бумагами. Произошло увеличение спекулятивной составляющей финансового рынка, что, облегчило незаконное перемещение капиталов.

Стоит отметить, что отток капитала из страны в больших объёмах происходит через банковский сектор. Банки, выдавая кредиты нерезидентам, переводят большие суммы денег на счета иностранных фирм.

Другой важной причиной оттока капитала из российской экономики является коррупция. После распада Советского Союза в 1991 году и начала 
либеральных рыночных реформ масштабы коррупции в современной России росли в геометрической прогрессии и приобрели угрожающие масштабы. По общепризнанному международному индикатору определения масштабов распространения коррупции - индексу восприятия коррупции (ИВК), который начиная с 1994 году ежегодно публикует международная организация «Transparency International», Россия в течение последних 20 лет относится к числу наиболее коррумпированных стран мира. В 2015 году в этом рейтинге из 167 исследованных стран Россия занимала 119-е место (между Гайаной и Сьерра-Леоной) [5]. В 2016 году Россия заняла 131-е из 176 мест в Индексе восприятия коррупции - 2016 (ИВК2016), который каждый год составляет международная организация Transparency International. Россия получила 29 баллов из 100, оказавшись в одном ряду с Ираном, Казахстаном, Непалом и Украиной. Рынок коррупционных услуг в России этой организацией оценивался в сотни миллиардов долларов [7].

Мировой опыт показывает, что наличие широкомасштабной коррупции свидетельствует о степени дисфункциональности экономики, то есть о серьезном нарушении в деятельности органов государственной власти и системы управления экономическими процессами. Эти проблемы характерны и для современной России. В стране не созданы надежные законодательный и административный механизмы, обеспечивающие защиту прав инвесторов, отсутствует эффективный государственный контроль за движением капитала.

Таким образом, в России сохраняется неблагоприятный инвестиционный климат, существуют значительные финансовые и моральные издержки при организации и поддержании бизнеса, в том числе малых и средних предприятий [8].

Согласно данным исследования международной компанией "Global Financial Integreti" (GFI), в период 1994-2012 года из России был незаконно вывезен 1341 млрд долларов. По данным ЦБ РФ, за 11 месяцев 2015 года чистый отток капитала из России составил 53 млрд долларов. Это в два раза меньше, чем за тот же период годом ранее. За период 2016-2017 годов ежегодный отток капитала составил 60 млрд долларов [7]. Объем оттока капитала из России превышал как объем притока прямых предпринимательских иностранных инвестиций, так и займы и кредиты международных финансовых организаций и двустороннюю финансовую помощь промышленно развитых государств.

Следует отметить, что в динамике оттока капитала из экономики России сохраняется высокая доля так называемых «сомнительных» операций.

В течение 20 лет в России объем «сомнительных» операций в вывозе капитала рос достаточно высокими темпами. В частности, если за период 1994-2001 годов объем «сомнительных» транзакций составлял 42 млрд долларов, то за период 2001-2012 годов их совокупный объем увеличился в 9 раз и составлял 341 млрд долларов. Объем «сомнительных» операций своего пика достигли в 2008 году, в период острой фазы 
мирового финансового кризиса, и составлял 51 млрд долларов. Доля «сомнительных» операций в общем оттоке капитала составила 38\%. В 2013 году, по данным Банка России, объем «сомнительных» операций превышал 27 млрд долларов. В 2014-2016 годах ежегодный объем «сомнительных» операций имел тенденцию к уменьшению. В 2015 году, согласно данным ЦБ РФ, этот показатель был равен 1,5 млрд долларов. Объем сомнительных финансовых операций в России в 2016 году сократился почти в двое по сравнению с 2015 годом и составил 800 млн долларов [9].

Большая часть «сомнительных» транзакций осуществлялась через схемы фиктивного импорта. Так, по данным Банка России, только в 2012 году стоимость оплаченных, но не полученных товаров и услуг по импортным контрактам в торговле с Беларусью составляла 15 млрд долларов, а в торговле с Казахстаном - 10 млрд долларов [10].

В последние годы недобросовестные компании активно использовали возможности, связанные с облегченными процедурами перемещения товаров и услуг, принятыми сначала в рамках Таможенного союза, а затем в Евразийском экономическом союзе. По оценкам Банка России, в 20122013 годах из России через страны, входящие в Таможенный союз, отток капитала за рубеж составил 47 млрд долларов [10].

Оплата внешнеторговых контрактов без исполнения договоров по поставке товаров часто используется как противоправная схема вывода капитала из России через оффшорные юрисдикции. В 2013 году объем невозвращенной из-за границы иностранной валюты по неисполненным экспортным договорам с оффшорными контрагентами составил сумму, эквивалентную 88 млрд рублей, в первой половине 2014 году - 67 млрд рублей [10].

Вывоз капитала также осуществлялся банками и прочими хозяйствующими субъектами, к которым относятся как крупные компании, так и предприятия малого и среднего бизнеса. Больше половины объема «сомнительных» операций во внешней торговле проводились через фирмыоднодневки и организации, прямо или косвенно связанные друг с другом платежными отношениями. Основной мотив коммерсантов при использовании фирм-однодневок и оффшорных юрисдикций при «сомнительных» операциях - не столько налоговая оптимизация, сколько сокрытие бенефициаров данных сделок.

Практическая реализация нелегальных схем вывода капитала из России, как правило, осуществлялась через коммерческие банки. Они выводили значительные финансовые средства за рубеж путем предоставления кредитов нерезидентам.

В России корпоративные облигации обычно выпускаются через зарегистрированные в оффшорных юрисдикциях SPV (компании специального назначения). Поэтому операции по покупке облигаций российских компаний или операции кредитования зарегистрированных за рубежом фирм, имеющих основные производственные мощности в России, согласно законодательству должны были быть оформлены как кредитование нерези- 
дентов. Банкам было выгодно кредитовать российские компании, зарегистрированные в зарубежных юрисдикциях. Такие сделки, как правило, заключаются в рамках английского права, что существенно повышает уровень защиты прав кредиторов и, соответственно, снижает риски финансовых операций.

Таким образом, часть оттока капитала из экономики России в последние годы носила специфический характер. Это был рост кредитования российских компаний, зарегистрированных в оффшорных юрисдикциях или действующих через иностранные юрисдикции.

Рассмотрим тенденции оттока капитала, наблюдаемые за 20162017 года.

Согласно данным ЦБ РФ за январь-ноябрь 2016 года предприятия частного сектора вывезли из России 16,1 млрд долларов. По сравнению с первыми одиннадцатью месяцами 2015 года отток капитала сократился более чем втрое - по итогам января-ноября 2016 года чистый вывоз оценивался в 54,1 млрд долларов [11]. Основной причиной сокращения оттока капитала является снижение интенсивности погашения внешних обязательств российскими банками. В то же время внешние обязательства прочих секторов экономики, по сравнению с прошлым годом, увеличились при сохранении сопоставимого уровня спроса на иностранные активы [12].

Сальдо текущего счета платежного баланса России в январе-ноябре 2016 года, по оценке Банка России, оказалось положительным, составив 22,2 млрд долларов. По сравнению с аналогичным периодом прошлого года показатель значительно сократился (было 63,7 млрд долларов), что объясняется сокращением экспорта товаров на фоне восстановления импорта [13]. По официальным данным платежного баланса за 23 года (19942017 годах), накопленный объем оттока капитала из России, рассчитанный как отрицательное сальдо счета операций с капиталом и финансовыми инструментами в частном секторе, оценивался в 826 млрд долларов [13].

Необходимо отметить, что по долгосрочному прогнозу Минэкономразвития РФ к 2020 году ввоз капитала в Россию может превысить его отток, что увеличит ресурсную базу долгосрочных инвестиций [14].

По данным Банка России в 2016 году россияне перевели за границу 35,9 млрд долларов. Из этой суммы на страны дальнего зарубежья приходилось 25,9 млрд долларов. (72\%), на страны СНГ - 10,0 млрд долларов. (28)\%. Средняя сумма одного денежного перевода составила 211 долларов. Самым популярным направлением перевода денежных средств россиянами является Швейцария. В эту страну в 2016 году физические лица перечислили 5,1 млрд долларов [2].

Вторым направлением оттока капитала россиян является Латвия, куда в 2016 году утекло 2,1 млрд долларов. По данным банковской системы Латвии, на российских граждан приходилось 53\% всех депозитов местной банковской системы. Третьим направлением оттока капитала российских физических лиц, как резидентов, так и нерезидентов были США. В 
2016 году в США из России было переведено 1,9 млрд долларов. Средняя сумма одного денежного перевода составила 477 долларов. В список 10 основных направлений оттока капитала российскими гражданами из России 2016 году вошли Китай (1894 млрд долларов), Великобритания (1862 млрд долларов), Германия (1146 млрд долларов), Испания (1136 млрд долларов), Кипр (1136 млрд долларов), Австрия (790 млн долларов) и Италия (680 млн долларов). В Россию из-за границы в 2016 году поступило финансовых переводов на общую сумму 18,4 млрд долларов, в том числе 15,5 млрд долларов (85\%) поступило из стран дальнего зарубежья и 2,9 млрд долларов (15\%) из стран СНГ. Больше всего денег россияне получили из Швейцария $(3,156$ млрд долларов), Латвия (1,693 млрд долларов) и США (1,417 млрд долларов), на которые приходилось почти треть всех финансовых поступлений из-за рубежа. Чистый отток капитала с учетом обратных переводов в Россию 2015 году составил 16,5 млрд долларов, а в 2016 году - 17,6 млрд долларов [2].

По данным «Credit Suisse Research Institute» в офшорных зонах общее накопленное благосостояние граждан России в 2016 году за рубежом оценивался в 2 трлн. долларов. Эта цифра включает в себя как финансовые, так и не финансовые активы. Стоимость финансовых активом граждан России за рубежом в 2016 году составляла примерно 1,2 трлн. долларов. К не финансовым активам относилась стоимость жилой и коммерческой недвижимости граждан России за рубежом. Зарубежной недвижимостью владели более 900 тыс. россиян, общей стоимость около 800 млрд долларов [2].

Последствия оттока капитала

Отток капитала оказывает многоплановое прямое и косвенное воздействие на различные сферы российской экономики и имеет существенные макроэкономические и социально-экономические последствия.

Вывоз капитала, не компенсируемый его равнозначным притоком изза рубежа, является одной из основных причин сокращения объема валовых внутренних инвестиций. При этом сокращается норма накопления в ВВП и, соответственно, снижаются возможности инвестиций в основной капитал, что сдерживает процесс расширенного воспроизводства.

Вывоз капитала в значительных размерах отрицательно воздействует на состояние платежного баланса России. В течение длительного времени положительное сальдо торгового баланса, за счет превышения экспорта товаров над их импортом, перекрывалось отрицательным сальдо движения капитала по текущим операциям (счета операций с капиталом и финансовыми инструментами).

Значительный отток капитала нарушает устойчивость финансовых рынков, в том числе валютного, приводит к разбалансированности и асимметрии основных его сегментов. Прибыль, полученная от инвестиционной деятельности, как правило, не реинвестируется в экономику России, а вывозится за рубеж.

Золотовалютные резервы России будут увеличиваться при отсутствии 
процесса оттока капитала за границу. Сокращение валютных резервов косвенно оказывает воздействие на курс рубля, что наиболее болезненно проявляется в периоды экономических и финансовых кризисов, например непредсказуемая динамика изменения курса национальной валюты в конце 2014 года.

Значительная часть финансовых ресурсов выводится за границу в целях уклонения от уплаты налогов, что напрямую негативно влияет на формирование доходной части бюджета и снижает финансирование государственных и социальных программ и проектов.

В результате значительного оттока капитала обостряется проблема нехватки капитала внутри страны для инвестиций в реальный сектор экономики. Недостаток инвестиционных средств препятствует, в частности, созданию новых производств, товаров и услуг и выходу на новые рынки, техническому переоснащению для повышения эффективности и конкурентоспособности российской продукции, а также проведению научных исследований и переобучению персонала [1].

Нехватка капитала стимулирует высокие ставки банковских кредитов, значительно превышающие уровень инфляции даже с учетом возможных банковских рисков. В результате формируется повышенный спрос на более дешевые международные кредитные и инвестиционные ресурсы.

Масштабный отток капитала сказывается на динамике основных макроэкономических показателей России и качественных характеристиках экономики, что в свою очередь влияет на изменение рейтинга конкурентоспособности России в глобальной экономике.

Отток капитала опосредованно влияет на динамику валютного курса, ослабление которого стимулирует рост потребительских цен. В результате в России в течение длительного периода времени сохраняется галопирующая инфляция, что снижает потребительский спрос и в конечном итоге негативно влияет на общий уровень жизни значительной массы населения страны, увеличивает долю бедных слоев населения.

Пути решения проблемы оттока капитала

Движение капитала и инвестиционная деятельность в рамках денежнокредитной политики должны регулироваться как рыночными, так государственными методами. В практическом плане для пресечения, сокращения и в итоге прекращения нелегальной утечки капитала за рубеж можно рассмотреть в качестве первоочередной меры возможность введения налога на финансовые спекуляции, прежде всего на их валютную часть. Под действие этого налога могут подпадать как «сомнительные» операции, так и краткосрочные операции спекулятивного характера. Это может быть временная мера до выхода страны на траекторию устойчивого развития.

Определенному сокращению оттока капитала из России, пополнению доходной части бюджета и улучшению инвестиционного климата может способствовать налоговая амнистия.

Федеральный закон №140-Ф3, принятый 8 июня 2015 года, предпола- 
гает добровольное декларирование физическими лицами своего имущества и счетов (вкладов) в банках за пределами Российской Федерации путем представления декларации в налоговый орган или в центральный аппарат Федеральной налоговой службы (ФНС) (по выбору физического лица). На такую декларацию будет распространяться режим налоговой тайны.

В пределах задекларированного имущества предприниматели единожды освобождаются от ответственности по самым «популярным» профильным статьям Уголовного кодекса: уклонение от репатриации денежных средств; уклонение от уплаты налогов и сборов; неисполнение обязанностей налогового агента; сокрытие денежных средств либо имущества, за счет которых должно производиться взыскание налогов. В обычной жизни санкции за указанные нарушения могут достигать до 5-6 лет заключения. Однако непременным условием успешной репатриации выведенных за рубеж капиталов являются четкие законодательные гарантии конфиденциальности и освобождения от уголовного преследования.

Еще одним обязательным условием удачной финансовой амнистии считается повышение доверия крупных предпринимателей и всего бизнес-сообщества к государственным и финансовым институтам страны.

\section{Заключение}

Таким образом, проблема оттока капитала имеет множество причин. С нашей точки зрения, нелегальный отток капитала из России является явлением, которое имеет наибольший экономический эффект, влияет на стабильность и безопасность российской экономики.

Для возвращения капитала в Россию следует, прежде всего, создать необходимые правовые условия, а это весьма длительный процесс формирования благоприятного инвестиционного климата, стимулирующего деятельность как иностранных, так и отечественных инвесторов.

Обеспечение благоприятного инвестиционного климата в России жизненно необходимо для реализации государством своих интересов как в международном плане, так и в вопросах экономического суверенитета. Без реализации продуманной и последовательной стратегии привлечения иностранных инвестиций, предоставляющей возможность исключить геополитические риски, Россия не сможет проводить независимую экономическую политику, так как в данный момент отток капитала является одной из важнейших проблем российской экономики.

References:

[1] Ашванян, С. К., Сапожникова, Т. А. Инвестиционный климат в России сквозь призму притока и оттока капитала / С.К. Ашванян, Т.А. Сапожникова // Вестн. Tом. гос. ун-та. Экономика. 2011. №3 (15). - Режим доступа: URL: http://cyberleninka.ru/article/n/investitsionnyy-klimat-v-rossii-skvoz-prizmupritoka-i-ottoka-kapitala.

[2] Макроэкономическая статистика Центрального Банка Российской Федерации [Интернет ресурс]. - Режим доступа: http://www.cbr.ru /statistics /?PrtId=macro_itm. 
[3] Проблемы оттока капитала из России // [Интернет ресурс]. - Режим доступа: http://www.ictsd.org/bridges-news/мосты /news/ проблемы-оттока-капитала-из-России.

[4] Объем теневой экономики РФ составил 39\% от ВВП. [Электронный ресурс] Режим доступа: http://www.newsru.com/finance/30jun2017/ shadoweconomy.html.

[5] Бернштам, Б. Е. Особенности «Бегства капитала» из России / Б.Е. Бернштам // Вестн. Том. гос. ун-та. Экономика. 2013. №3 (23) // [Интернет ресурс]. - Режим доступа: URL: http:// cyberleninka.ru / article/n/osobennosti-begstva-kapitala-izrossii.

[6] Доклад Tax Justice Network // [Интернет ресурс]. - Режим доступа: http: // www.fondsk.ru/pview/2013/01/23/chernye-dyry-mirovoj-ekonomiki-i18813.html.

[7] Мельников, А. Б., Романенко, Р. Г. Инвестиционный климат и отток капитала в системе основных рисков устойчивости экономики России / А.Б. Мельников, Р.Г. Романенко // Научный журнал КубГАУ - Scientific Journal of KubSAU. 2014. №100 // [Интернет ресурс]. - Режим доступа: URL: http://cyberleninka.ru /article/n/ investitsionnyy-klimat-i-ottok-kapitala-v-sisteme-osnovnyh-riskovustoychivosti-ekonomiki-rossii.

[8] Каковы ключевые причины оттока капитала из России // [Интернет ресурс]. - Режим доступа: https: //arb.ru/b2b/duty/ kakovy_klyuchevye_prichiny_ottoka_kapitala_iz_rossii-2021648 / sphrase_id = 89738.

[9] Кремлю не удалось победить офшоры // [Интернет ресурс]. - Режим доступа: http: // svpressa.ru/economy /article /170316.

[10] Официальный сайт Всемирного банка // [Интернет ресурс]. - Режим доступа: http: //www.worldbank.org / eca / russian/.

[11] Отток капитала из России сократился более чем втрое // [Интернет ресурс]. Режим доступа: http: // www.rbc.ru /rbcfreenews / 584aad7b9a794724d18ae7d5.

[12] Пономарев, А. В., Борисенков, В. А. О взаимосвязи внешнего долга и оттока капитала из России / А.В. Пономарев, В.А. Борисенков // Вестник МГИМО. 2012. №6 // [Интернет ресурс]. - Режим доступа: URL: http:// cyberleninka.ru /article/n/o-vzaimosvyazi-vneshnego-dolga-i-ottoka-kapitala-iz-rossii.

[13] Официальный сайт ЦБ РФ. [Электронный ресурс] - Режим доступа: http://www.cbr.ru.

[14] Прогноз долгосрочного социально-экономического развития Российской Федерации на период до 2030 года / Минэкономразвития России [Электронный pecypc]. - Режим доступа: http:// www.economy.gov.ru /wps/wcm/connect/economylib4/mer/activity/sections/macro/prognoz/ doc20131108_5 


\title{
ANIMATION - THE IMPORTANT ELEMENT OF PERSPECTIVE DEVELOPMENT OF RURAL TOURISM IN REGIONS OF UZBEKISTAN
}

\author{
M. Alimova ${ }^{1}$, Sh. Rakhmonov ${ }^{2}$
}

\begin{abstract}
In article the possibilities and the perspective directions of development of rural tourism in regions of Uzbekistan are considered. At the same time use of animation programs as a basic element of advance of this tourist product in the market of tourism of Uzbekistan is offered.
\end{abstract}

Keywords: tourism, ethnographic tourism, potential, animation.

Туризм является мощным катализатором социально-экономического развития как развитых, так и развивающихся стран, и регионов, так как он обеспечивает приток иностранной валюты, инвестиций, способствует бурному росту смежных отраслей, помогает решать проблемы занятости населения. Он может дать мощный толчок в социально-экономическом развитии, в странах и отдельных регионах, имеющих высокий туристский потенциал.

Не исключением является и Узбекистан, испокон веков славившийся своими древними городами, казна которых солидно пополнялась за счёт купцов и путешественников. Узбекистан обладает высоким туристско-рекреационным потенциалом. На его территории насчитывается более 7 тысяч памятников истории, многие из которых включены в Список всемирного наследия ЮНЕСКО. В их числе такие жемчужины Востока, как города Самарканд, Бухара, Хива, Шахрисабз, Ташкент, Коканд, Термез. Уникальное расположение Узбекистана на Великом шелковом пути является ключевым фактором развития туристской сферы страны.

Наличие разнообразных туристско-рекреационных ресурсов страны позволяет развивать различные виды туризма, в том числе рекреационный, культурно-познавательный, деловой, активный, оздоровительный, экологический, спортивный, а также сельский туризм. Одним из приоритетных, на наш взгляд, видов туризма, на который необходимо обратить внимание в процессе развития данной индустрии и привлечения дополнительного числа туристов, является сельский туризм. Для регионов Узбекистана это направление может стать одним из важных источников получения доходов для сельских территорий и рыночной нишей для многих сельских предпринимателей.

Сельский туризм - это целенаправленные путешествия на сельские территории с относительно ненарушенными экосистемами и этнокультурными комплексами, обеспечивающие непосредственный вклад в решение

\footnotetext{
${ }^{1}$ Mashkhura Alimova, Doctor of Economics, Samarkand institute of economy and service, Uzbekistan.

${ }^{2}$ Shukhrat Rakhmonov, student, Samarkand institute of economy and service, Uzbekistan.
} 
проблем сельского населения и подлежащие адекватному режиму управления на основе устойчивого развития [1].

Мультипликативно сельский туризм, особенно в условиях реализации целевых программ развития, оказывает позитивное влияние на сохранение и развитие сельских территорий, рациональное использование их ресурсного потенциала, стимулирует развитие личных подсобных хозяйств, расширяя спрос на экологически чистые, натуральные продукты питания, а также обустройство сельских территорий, сельское строительство, народные промыслы, культуру и самобытность, т.е. в целом на решение социально-экономических проблем сельских территорий, прежде всего проблем занятости населения сельской местности[2]. Активное развитие этого нового сектора экономики могло бы помочь в решении задач, стоящих перед нашим государством, селом - с одной стороны, и перед туристской отраслью - с другой.

Мировой опыт показывает, что во многих сельских регионах, обладающих значительным географо-экологическим, природно-рекреационным, социально-экономическим и культурно-историческим потенциалом, развитие сельского туризма может стать весьма эффективной деятельностью в контексте их социально-экономического развития (рис.1).

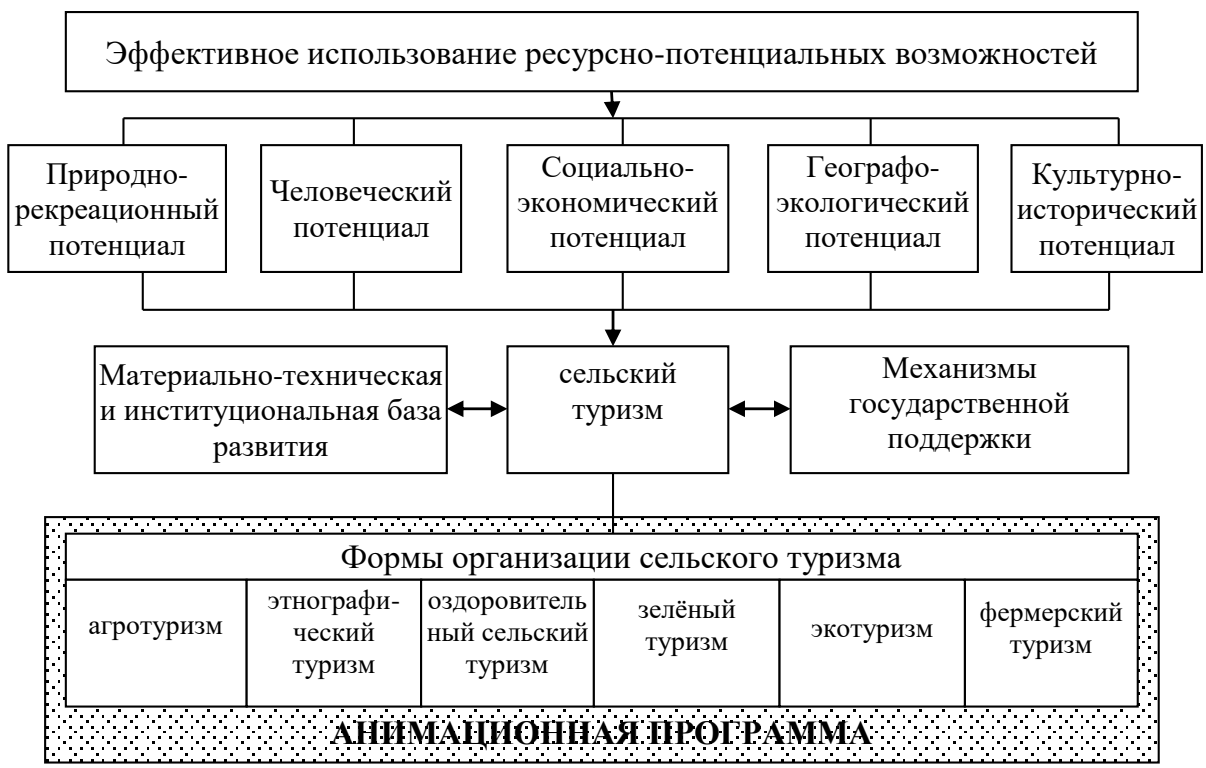

Рис.1. Условия и направления развития сельского туризма в регионах Узбекистана 
В этой связи возникает необходимость принятия республиканских и региональных программ развития сельского туризма. В них должны быть отражены конкретные меры по созданию материально-технической, институциональной (правовой, социальной) базы для развития сельского туризма, механизмов (организационного, экономического, финансового) его поддержки со стороны государственных и местных органов власти, а также других предпосылок и условий, призванных сформировать благоприятный климат для потенциальных субъектов туристского бизнеса. При этом эффективное развитие туризма в сельской местности требует определённую материально-техническую и институциональную базу, включающую нормативно-правовое, кадровое, информационное обеспечение развития с чётко сформированными механизмами государственной поддержки.

В мировой практике нет единого подхода по развитию сельского туризма в определённой местности. На сегодняшний день в мире существуют многообразные формы организации сельского туризма, которые развиваются в местности, при наличии в данной местности необходимых ресурсов для их формирования. На рисунке-1 приведены некоторые формы организации сельского туризма, которые можно развивать в сельских местностях Республики Узбекистан.

Увеличение количества объектов, предоставляющих услуги в сфере сельского туризма, неизбежно ведет к усилению конкуренции по всему миру. Как следствие, возникает необходимость поиска способов разнообразить номенклатуру оказываемых услуг с целью удержания существующих клиентов и привлечения новых. Между тем в практике туризма все большее значение приобретает анимация, как деятельность по разработке и предоставлению специальных программ проведения свободного времени и одна из главных конкурентных преимуществ сельского туризма перед другими видами туризма.

Анимация - сравнительно новое направление туристской деятельности, предполагающее личное участие туристов в игровых и театрализованных шоу-программах, спортивных и культурно-развлекательных мероприятиях, направленных на ознакомлении туристов с культурой, обычаями и традициями местного народа.

Традиции и обычаи узбекского народа формировались веками. Узбекский этнос является одним из самых древних этносов, когда-либо существовавших на планете. Кроме того, это самый многочисленный этнос в Средней Азии. Самобытная культура народов Узбекистана сформировалась на заре цивилизации, уже в IV в до н.э. Соблюдение обычаев и традиций всегда было долгом каждого человека, независимо от его происхождения и социального статуса. Узбекский народ имеет богатое историческое прошлое, страницы его истории неразрывно связаны с историей Средней Азии. Земля Узбекистана - это своеобразный драгоценный архив, хранящий уникальные исторические и археологические памятники разных эпох, богатое культурное наследие, которое отражается в разнообразных обычаях и традициях, сохранившихся по сегодняшний день. Культура Уз- 
бекистана одна из самых ярких и самобытных культур Востока, она формировалась в течение тысячелетий и вобрала в себя традиции, обычаи народов, в разное время населявших территорию современного Узбекистана. Свой вклад внесли в нее древние иранцы, греки, кочевые тюркские племена, арабы, китайцы, русские. Великий Шелковый Путь способствовал слиянию культур народов, их обычаев и искусства. Всё это может служить основой для развития этнографического туризма, как ведущего направления развития туризма во всех регионах, особенно в сельских местностях Узбекистана.

Важным элементом в организации тура с этнографическим ознакомлением может играть анимация. Анимация - это своеобразная услуга, преследующая цель повышения качества обслуживания, и в то же время - это своеобразная форма рекламы, повторного привлечения гостей и их знакомых, тоже преследующая цель продвижения туристского продукта на рынке для повышения доходности и прибыльности турбизнеса.

Как один из актуальных направлений организации обслуживания туристов в сельской местности анимация - это оживление программ обслуживания, отдыха и досуга туристов, насыщение этих программ игровыми элементами и шоу-продуктами. Именно использование анимационных программ может служить важным толчком развития сельского туризма в регионах Узбекистана. При этом анимация является также определенной формой рекламы, которая преследует цель продвижения туристского продукта на рынке для повышения доходности и прибыльности туристского бизнеса.

При организации сельского туризма анимация может быть применена по следующим основным направлениям: ознакомление с национальными культурными традициями и организация спортивно-оздоровительных мероприятий (например, «купкари»). Первое направление включает в себя проведение традиционных народных праздников, фестивалей, мастерклассов по кулинарии, декоративно-прикладному искусству (ткачеству, вышивке, изготовлению изделий из глины, дерева, соломы), при этом обязательно - с непосредственным участием гостей. При разработке таких программ хозяевам принимающих туристов, а также специалистам сельскохозяйственных организаций рекомендуется отдавать предпочтение традициям и обрядам, характерным для данной местности.

На сегодняшний день бурное развитие сельского туризма в регионах Узбекистана сдерживается некоторыми препятствиями, возникающими на пути его продвижения. Основные проблемы развития сельского туризма в регионах Республики Узбекистан:

- потребность для сельского туризма в нормативно-правовой и законодательной базе;

- отсутствие целевой государственной программы с финансовым обеспечением развития сельского туризма;

- несовершенство механизмов по созданию благоприятного инвестиционного климата в сфере сельского туризма; 
- неразвитость инфраструктуры сельских территорий, в том числе дорожной сети, транспортного, бытового обслуживания и т. д.;

- недостаточная информированность сельских жителей о возможностях сельского туризма;

- отсутствие квалифицированных кадров в сфере сельского туризма и т.д.

Поэтому для реализации имеющихся возможностей для развития сельского туризма в регионах Республики Узбекистан нужно создать необходимые условия, а именно:

- создание законодательной базы регулирования рынка сельского туризма;

- обеспечение целевого финансирования и господдержки малых предпринимателей, заинтересованных в развитии сельского туризма;

- стимулирование инвестиций в развитие внутреннего сельского туризма;

- развитие туристской инфраструктуры в сельской местности;

- стимулирование развития малого бизнеса для оказания сопутствующих туризму сервисных услуг;

- разработка учебных программ для подготовки кадров для сельского туризма и сопутствующих отраслей;

- поддержка продвижения региональных сельских туристских продуктов на внутреннем и международном рынках туризма.

И так, реализация имеющихся возможностей даст толчок для бурного развития сельского туризма в регионах Узбекистана. Правильно спланированный и организованный сельский туризм может стать одним из перспективных направлений структурной перестройки экономики села, фактором возрождения и социально-экономического развития сельских территорий страны. При этом анимация, являясь определённой формой рекламы, может служить как важный элемент продвижения данного туристского продукта на рынке туризма.

References:

[1] Казьмина Е.Б. Развитие услуг сельского туризма в российских регионах [Электронный ресурс] http://www.guu.ru/files/referate/kazmina.pdf

[2] Кундиус В.А., Чермянина В.В. Проблемы и перспективы агротуризма в регионе // Известия Алтайского государственного университета. - 2011. - № 2. - С. 289. // электронный ресурс - http://izvestia.asu.ru/2011/2-1/econ/06.ru.html

[3] Гаранин Н.И. Менеджмент туранимации в туркомплексах // Актуальные проблемы туризма. - М., 1999. - С. 50 - 58. 


\title{
THE PROBLEMS ASSOCIATED WITH IMPORT SUBSTITUTION IN THE AGRICULTURAL SECTOR OF THE REGION BY THE EXAMPLE ORENBURG REGION
}

\author{
M. Grinevich ${ }^{1}$, D. Filatova ${ }^{2}$
}

\section{Abstract}

This article examines problems in the field of agriculture and village infrastructure of Russia on the example of Orenburg region in terms of sanctions and the food embargo. The calculated Pearson correlation coefficient between the volume of investment and volume of production and the close connection between these indices.

Keywords: import substitution, agriculture, development.

В условиях кризиса российской экономики, начавшегося в 2014 году, одним из наиболее актуальных направлений в России стало активная поддержка импортозамещению сельскохозяйственной и промышленной продукции.

Ранее вопросы, связанные с импортозамещением, рассматривались как методы для модернизации экономики России, однако на современном этапе они являются ключевым аспектом обеспечения внутренней безопасности страны. Необходимо отметить, что на сегодняшний день импортозамещение для России оценивается как шанс для выхода национальной экономики на устойчивые темпы роста ВВП. Но как бы заманчиво это не звучало, развитие сельского хозяйства признается убыточным бизнесом, именно поэтому привлечение предпринимателей в область АПК - задача очень сложная. Проблема импортозамещения в сельском хозяйстве имеет комплексный характер и включает в себя множество различных вопросов, каждый из которых требует немедленного решения и денежных вложений.

В России сегодня действуют федеральные целевые программы. Так, в соответствии с распоряжением Правительства Российской Федерации от 2 февраля 2015г. № 151-р «Стратегия устойчивого развития сельских территорий Российской Федерации на период до 2030 года» одним из центральных направлений деятельности государства является повышение уровня жизни в селе. Стоит отметить, что с 2014 года действовала утвержденная постановлением Правительства Российской Федерации от 15 июля 2013г №598 федеральная целевая программа «Устойчивое развитие сельских

\footnotetext{
${ }^{1}$ Maria Grinevich, student, Financial University under the Government of the Russian Federation, Russia.

${ }^{2}$ Darya Filatova, student, Financial University under the Government of the Russian Federation, Russia.

Supervisor: Sharkova Antonina Vasilievna, doctor of economic Sciences, Professor, head of chair "Economics of organization" of the Financial University under the government of the Russian Federation.
} 
территорий на 2014-2017 годы и на период до 2020 года». А ранее, до 2013 года главным инструментом реализации развития сельских территорий являлась утвержденная постановлением Правительства Российской Федерации от 3 декабря 2002г. №858 федеральная целевая программа «Социальное развитие села до 2013 года». [1]

Вышеперечисленные федеральные программы признаны эффективными. Доказательством этому служат показатели, которые свидетельствуют о сравнительном улучшении жизни в селе.

Так, в России, согласно статистическим данным 265,7 тыс. сельских семей улучшили свои жилищные условия. Уровень газификации поселков значительно вырос (с $33,1 \%$ до 56,5\%), стоит отметить, что также увеличился показатель обеспеченности сельского населения (на 18,9\%). Большое внимание государство уделило развитию образования в селах. Так, 105,8 тыс. дополнительных ученических мест государство предоставило детям в общеобразовательных школах. В то же время, в культурно-досуговых учреждениях в 2015 году появилось 24,6 тыс. мест, спортивных площадок - 304 единицы. Что касается сферы медицинского обслуживания сельского населения, то сеть районных больниц увеличилась на 6,1 тыс. мест. [2]

Но, несмотря на относительные успехи в развитии села, многие проблемы в данной области остаются нерешенными. Так, рассмотрев конкретные области, края и другие территориальные единицы РФ уровень жизни в селе остается очень низким.

Стоит отметить, что сегодня в России существует многоканальное финансирование российских предприятий:

- частное финансирование;

- государственное прямое финансирование (госзаказы, федеральные целевые программы);

- государственное косвенное финансирование (льготные налоговые условия, госзакупки);

- гибридное финансирование (государственно-частное партнерство).

Заметим, что существует большое число направлений влияния государства на конкурентоспособность российских предприятий. Однако многие из них нуждаются в более подробном анализе и требуют корректировки. [1]

Для того, чтобы определить роль государственной поддержки агропромышленного комплекса, необходимо обратиться к основным проблемам развития села (на примере Оренбургской области), а также проанализировать конкретные показатели. Вследствие обзора экономических источников, наиболее ключевыми и значимыми факторами являются:

- социальный уровень, социальная инфраструктура села;

- техническое состояние отрасли;

- уровень инвестиционной активности;

- инновационная составляющая;

- качество продукции;

- уровень издержек предприятий в отрасли; 
- налоговая среда;

- отдельные характеристики товаров, степень дифференциации;

- уровень квалификации персонала на предприятиях, условия труда и т.д.

Более подробно рассмотрим некоторые из них.

1. Социальный уровень развития села.

Территория Оренбургской области является одной из особо значимых агропромышленных районов в Российской Федерации, здесь производится множество видов растениеводческой продукции. Но, стоит отметить, что сегодня одной из наиболее острых проблем на данной территории является катастрофическая нехватка сельского населения, так, согласно статистическим данным, на 1 января 2015 года численность населения области - 2001,1 тыс. человек, сельское население - 802,6 тыс. человек $(40,1 \%) .[5]$

Данная проблема является следствием недофинансирования, в частности, государством социальной сферы в селе. Отметим, что сегодня наблюдается постоянный отток сельского населения в город, так за 10 лет (2005$2015 г г$.) численность людей, проживающих в селе, снизилась на 9,3\% (таблица 1).

Таблица 1

Численность населения

\begin{tabular}{|l|c|c|c|c|c|c|}
\hline & $2005 г$. & $2010 г$. & 2012 г. & $2013 г$. & 2014 г. & $2015 г$. \\
\hline Население, тыс. чел. & 2122,4 & 2033,1 & 2023,7 & 2016,1 & 2008,5 & 2001,1 \\
\hline в том числе: & & & & & & \\
\hline - городское & 1237,7 & 1214,0 & 1206,1 & 1202,8 & 1202,0 & 1198,5 \\
\hline - сельское & 884,7 & 819,1 & 817,6 & 813,3 & 806,5 & 802,6 \\
\hline $\begin{array}{l}\text { Удельный вес в общей } \\
\text { численности населения, } \\
\text { в процентах: }\end{array}$ & & & & & & \\
\hline - городское & 58,3 & 59,7 & 59,6 & 59,7 & 59,8 & 59,9 \\
\hline - сельское & 41,7 & 40,3 & 40,4 & 40,3 & 40,2 & 40,1 \\
\hline
\end{tabular}

Источник: Статистический ежегодник Оренбургской области.

Более того, на каждого сельского трудоспособного жителя приходится один нетрудоспособный. Наблюдаемая за последние 10 лет тенденция увеличения доли нетрудоспособного населения (на 5,8\%) и сокращение трудоспособного (на 5,8\%) связана, в первую очередь, с вышеуказанными миграционными процессами. И в соответствии с демографическим прогнозом, составленным экспертами, численность сельского населения будет неуклонно сокращаться (таблица 2).

Таблица 2

Демографический прогноз. чел.

\begin{tabular}{|l|c|c|c|c|}
\hline & $2016 г$. & $2020 г$. & $2025 г$. & $2030 г$. \\
\hline Всего, в т.ч.: & 802581 & 784905 & 753656 & 721080 \\
\hline - мужчин & 384841 & 378581 & 366254 & 354031 \\
\hline - женщин & 417740 & 406324 & 387402 & 367049 \\
\hline
\end{tabular}


Источник: Статистический ежегодник Оренбургской области. 2015г.

Тем не менее, не стоит отрицать и государственный вклад в развитие инфраструктуры в сельской местности. [2] Так, сегодня, государство активно проводит политику привлечения людей в село. Так, среднемесячные номинальные начисления заработной платы населения, занятого в сельском хозяйстве за 15 лет выросла на 12209,9 руб, площадь жилых помещений, приходящаяся в среднем на одного сельского жителя увеличилась на $6,8 \mathrm{~m}^{2}$, также улучшилось благоустройство населенных пунктов (число поселков, имеющих водопровод выросло на 10) и т.д.

Но, несмотря на такую, казалось бы, успешную социальную политику, число занятых в сельском хозяйстве сократилось на $6,8 \%$ в сравнении с предыдущим годом. Это говорит о том, что сегодня необходимы большие вложения в развитие не только социальной сферы, но и в сферу производства сельскохозяйственной продукции как со стороны государства, так и со стороны населения.

2. Техническая оснащенность.

Снижение производства основных продуктов сельскохозяйственными организациями за последние 15 лет (почти на 3\%) неразрывно связано с недостаточным количеством сельхозтехники. Так, статистика показывает, что в настоящее время наблюдается неуклонное сокращение количества располагаемых сельскохозяйственными организациями машин (таблица 3)

Таблица 3

Наличие тракторов и сельскохозяйственных машин в сельскохозяйственных организациях, тыс.шт.

\begin{tabular}{|l|c|c|c|c|c|c|c|}
\hline & $2000 г$. & $2005 г$. & $2010 г$. & $2012 г$. & $2013 г$. & $2014 \Gamma$. & $2015 г$. \\
\hline Тракторы & 24,9 & 17,8 & 11,0 & 9,7 & 8,8 & 7,8 & 7,1 \\
\hline Комбайны: & & & 3,5 & & & & \\
зерноуборочные & 8,5 & 6,1 & 0,5 & 3,0 & 2,7 & 2,4 & 2,2 \\
кормоуборочные & 1,7 & 1,0 & 0,4 & 0,4 & 0,4 & 0,3 \\
\hline Плуги всех видов & 7,5 & 5,0 & 2,6 & 2,2 & 2,1 & 1,9 & 1,8 \\
\hline Культиваторы трак- & & & & & & & 1,9 \\
торные всех видов & 8,4 & 6,2 & 4,1 & 3,8 & 3,5 & 3,2 & \\
\hline Сеялки тракторные & 18,2 & 14,8 & 9,5 & 7,9 & 7,2 & 6,4 & 5,7 \\
\hline Жатки валковые & 3,8 & 2,5 & 1,4 & 1,2 & 1,1 & 1,0 & 0,9 \\
\hline
\end{tabular}

Источник: Статистический ежегодник Оренбургской области.

На сегодняшний день наблюдается значительное повышение цен на сельхозтехнику и сельхозтоваропроизводители не имеют финансовой возможности обновлять свой автопарк. И основным решением этой проблемы является еще большее привлечение инвестиций, как со стороны государства, так и со стороны частных инвесторов. [1]

3. Уровень инвестиционной активности

Сегодня мы наблюдаем нестабильные инвестиционные вложения в сферу агропромышленного комплекса (таблица 4). 
Инвестиционные вложения в сферу АПК, млн.руб

\begin{tabular}{|l|c|c|c|c|c|c|}
\hline & 2002 г. & 2005 г. & 2012 г. & $2013 г$. & 2014 г. & $2015 г$. \\
\hline $\begin{array}{l}\text { Инвестиции в основной } \\
\text { капитал }\end{array}$ & 458,4 & 1853,9 & 3153,3 & 2465,6 & 2012,8 & 2051,1 \\
\hline $\begin{array}{l}\text { Финансовые вложения } \\
\text { организаций }\end{array}$ & 351,4 & 347,0 & 1633,5 & 2257,1 & 1055,2 & 1577,1 \\
\hline
\end{tabular}

Источник: Статистический ежегодник Оренбургской области.

Данные вложения в развитие отраслей АПК являются долгосрочными и существует большая вероятность риска потери денежных средств. Именно поэтому, сегодня мы не можем говорить о привлекательности частных инвесторов в данную сферу. В настоящее время необходимо провести целый комплекс мер для создания благоприятных условий инвестиционной привлекательности, а именно:

- оптимизация всех расходов производства сельскохозяйственной продукции;

- реструктуризация организации труда производства;

- обслуживающие отрасли производства и хозяйства необходимо поставить в материальную зависимость от объемов производства продукции;

- обеспечение соблюдения трудовой дисциплины.

Для получения реальных результатов в достижении стабилизации экономической ситуации на селе при помощи инвесторов, вышеперечисленные меры требуют немедленной реализации.

4. Инновационная составляющая.

Как известно, развитие науки является необходимым условием перехода национальной экономики на новый этап развития. Недостаточный уровень технической оснащенности, отсталость технического прогресса в области АПК - все это связано с недостаточным вложением денежных средств в научные проекты и разработки. В 2000-2012 гг. количество исследователей в данной области увеличивается, а в последующие два года наблюдается резкое сокращение численности ученых (таблица 5).

Таблица 5

Численность исследователей в области сельскохозяйственных наук

\begin{tabular}{|l|c|c|c|c|c|c|c|}
\hline Годы & $2000 г$. & $2005 г$. & $2010 г$. & $2012 г$. & $2013 г$. & $2014 г$. & $2015 г$. \\
\hline $\begin{array}{l}\text { Исследователи, } \\
\text { чел }\end{array}$ & 161 & 168 & 163 & 168 & 156 & 147 & 140 \\
\hline
\end{tabular}

Источник: Статистический ежегодник Оренбургской области.

Низкий уровень заработной платы ученых и невозможность проведения научно-исследовательских работ из-за нехватки необходимых материальных средств являются причиной застоя научно-технического_прогресса в данной отрасли. Сегодня необходимо активное привлечение молодых ученых и материально-техническое оснащение научно-исследовательских центров в данную сферу. 
В заключении хотелось бы сказать, что импортозамещение - несомненно, сегодня очень важный процесс, обеспечивающий подъем национальной экономики на новый уровень развития, более того, он жизненно необходим для нашего государства. Но, в то же время, это очень непростая задача, решение которой требует масштабные и радикальные изменения в общественном строе:

- проведение масштабной целевой государственной поддержки развития АПК;

- обеспечение высокого уровня осведомленности предприятий о реализуемых мерах господдержки и устранение препятствий в процессе получения информации;

- организация полноценной и эффективной функционирующей инфраструктуры продвижения отечественной продукции;

- обеспечение доступа предприятий реального сектора экономики к кредитным ресурсам;

- поддержка высокого уровня инновационной активности хозяйствующих субъектов;

- повышение квалификации кадров.

Стоит отметить, что особенность агропродовольственного рынка заключается в том, что на нем реализуются товары первой необходимости, базисные продукты питания, что делает рынок социально значимым. Именно поэтому данная сфера требует особого государственного внимания.

References

[1] Шаркова А.В., Харитонова Т.В., Белобрагин В.В., Бурак П.И., Зворькина Т.И., Меркулина И.А., Шапкин И.Н., Маркина И.А., Морозов М.А., Морозова Н.С., Морозов М.М., Харитонова Е.Н., Алесина Н.В., Дашков Л.П., Вьюник А.В., Ахметшина Л.Г., Аль-Малики Р.С.М., Пономарева М.А., Бандуристова О.В., Цхададзе Н.В. и др. Развитие предпринимательства и бизнеса в современных условиях: методология и организация //М.А. Эскиндаров. -М.: Москва, 2017 - 466 с.

[2] Шаркова А.В. Влияние процесса глобализации на использование трудового потенциала национальной и мировой экономики//Проблемы современной экономики. 2003. № 3-4. С. 78-79.

[3] Шаркова А.В., Килячков А.А., Маркина Е.В., Солянникова С.П., Чалдаева Л.А. Словарь финансово-экономических терминов// М.А. Эскиндаров. -М.: Москва, 2017 $-206 \mathrm{c}$.

[4] Шаркова А.В., Харитонова Т.В. «Петля качества» для организаций гостеприимства//Стандарты и качество. 2016. №7. С.98-101

[5] Федеральная целевая программа "Устойчивое развитие сельских территорий на 2014 - 2017 годы и на период до 2020 года".

[6] Распоряжение Правительства Российской Федерации от 2 февраля 2015г. № 151-р «Стратегия устойчивого развития сельских территорий Российской Федерации на период до 2030 года» Электронный pecypc: [http://government.ru] (Дата обращения: 28.03.2017 г.)

[7] Статистический ежегодник Оренбургской области. Электронный ресурс [http://orenstat.gks.ru] (Дата обращения 29.03.2017 г.) 


\section{INNOVATION MARKETING AND ITS IMPORTANCE}

\section{A. Ergashev ${ }^{1}$}

\section{Abstract}

The article reveals for the essence of innovation marketing and there are given the analyses of scientific views on the role of innovation marketing in management of enterprise. It is defined the difference between the traditional and innovational marketing. The functions of marketing in market success of innovational products are studied.

Keywords: innovation, innovation marketing, branding, marketing of communication, market of innovations.

The term "innovation" has come into the life activities deeply. There are also innovations features in the marketing field. This article describes the role of the innovation in the marketing processes and formations its views.

Nowadays, the academic economists consider that the fourth industrial revolution is close. As we know, the global innovations cause to every single the industrial revaluations. Therefore, in every sphere including in the marketing innovation approaches are considered importantly characteristics. As P. Drukker said "...there are two and only two functions of the company: marketing and innovations" [1].

Another economist Neeraj Davar emphasized that innovations firstly relevant to goods and technologies and managers take into consideration the set of the ideas, the matters of selling and recycling of productions are meant to the managers to explore more about market mechanisms [2].

It is obvious that the achievements of science not only relevant to the productivity and technology, but also significant to improve the role of marketing research.

It is worthy to recall of P. Druker citation that "the aim of the business is to bring to the existence of customers, so, there are two functions of the business companies: marketing and innovations. The marketing and innovations are to create profitable the results, the rest of them are expenses [3]."

The innovation marketing is the part of companies' strategic plan and it might to appear in different forms. One of them, based on the demand of customers, the formation or establishment of new service or products. In other words, eliminating the customers to be asked questions such as "What would you like?" instead of it should be provided the services and products that could improve their lifestyle. The implementation of these, are required to observe the customers behavior and organizing the essential marketing researches. In this context, it is important to recall the citation by the founder automobile industry Henry Ford "If I had asked people what they wanted, they would ride cart"[3].

\footnotetext{
${ }^{1}$ Alijon Ergashev, Senior teacher economics, Fergana State University, Uzbekistan.
} 
So, the innovations run to know the desires in advance. Often the customers are not able to express clearly determination of needs. The customer may give his evaluation if new product or service are offered. It runs as the main principles of innovation marketing as it follows: the creation a new product or modifying the technology of manufacturing, ultimately produce the new quality product.

As it is shown at Figure 1, the innovation products are at initial stage, when it enters to the market only the a few of oriented customers pay attention. These a few customers are those who are willing to news things or curious of new products. Therefore, at this stage the innovation products are not categorized as succeeded or failed. However, the company should explore about the existence, termination or further developments of the product. As we can see from the figure, the adaptation of the new product requires the certain period of time.

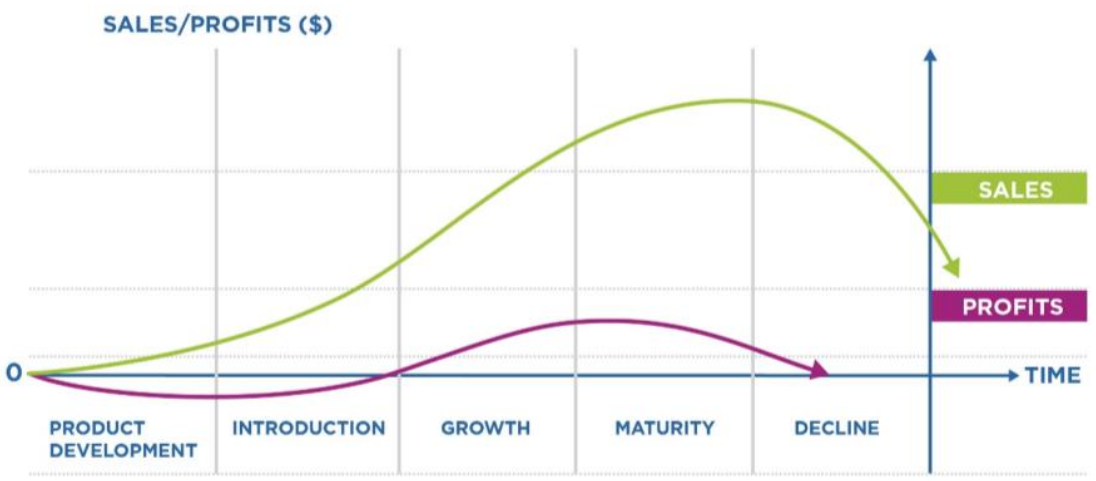

\section{PRODUCT LIFE CYCLE}

Figure 1. The life cycle of the product: trend of profits and sales [4]

In traditional marketing, department of marketing or marketer of company were believed to bring the product to market, modify product, satisfy of customers demand and implement marketing researches. Obviously, it is not true. The innovation groups should be consisted of the company's other field experts such as managers, technologists, and engineers, because it is an essential.

Nowadays, PR and advertisement companies take innovative approaches through gadgets and phones. As internet service has being developed, the web environment also is being widened.

In other words, the innovative environment consists of three elements, formation demand and supply:

-Market of news;

-Market of innovative business;

-Market of investment.

The market of news are run by innovation projects, all of them need to be funded and implemented. For example, the creation free economic zone in case 
of Inha University in Tashkent is caused to flow foreign direct investments in order to develop of information technologies. When the project is implemented in the practice, it turns to the innovation.

Innovative business are formed by the companies that provide market of news, implementations of know-hows and users. Such companies consist of implementations firms, and user who utilize the news in their activities.

In other words, innovation is pioneer in the economy, it creates new ideas, goods, services and regularly chases after updates. Besides, innovators are those who implements the updates and investors, particularly they are supporters of new ideas and the projects.

In the innovation market the most of percentages are linked to followers and those who are waiting. They are reached to $80-90$ percentage of the market segment. The interesting part is they assume themselves as pioneers and innovators the mostly. It causes to down our economy.

One of indicators of the economic developments of the Republic of Uzbekistan is the capital that spends over the capital and it causes creating an innovation marketing. For example, according to the stat info, in 2015 the 40737.3 billion sums investment was directed to assets. (23,3\% of GPP), in 2016 it reached to 49476.8 billion sums (24.8\% of GPP) and in 2017 it is expected to be $109.6 \%$ [5].

However, it can not indicate the effectiveness of the innovation process. Moreover, the following factors should be taken into account:

-Innovative potential of the organization;

-The direction of innovative activity;

-Innovative progress, that is, the rate of development;

-Marketing strategy.

Also, as far we are concerned, the development of innovative marketing should be covered by innovative infrastructure-innovation-technical centers, scientific-technical information centers, marketing firms, patent offices, jurisprudential firms, business incubators, techno parks

\section{References}

[1] P.F. Drucker, 2007, Management: tasks, responsibilities, practices, Transaction Publishers, New Brunswick, N.J.; London.

[2] Niraj Dawar, When Marketing Is Strategy, Harvard Business Review Press, 2013.

[3] Mats Urde, Core value-based corporate brand building, // https://www.marketing.research.

[4] https://courses.lumenlearning.com/marketing-spring2016/chapter/readingstages-of-the-product-life-cycle/ · (Дата обращения 25.03.2017)

[5] Electronic source: https://www.stat.uz 


\section{THE IMPORTANCE OF YOUTH TOURISM}

\section{Khusenova ${ }^{1}$}

\section{Abstract}

In our globalized area, most people tend to travel and explore new things, including youth. The number of young tourists has been growing year by year. There different organizations and opportunities that enables youth to travel as many times as they want. Young people are energetic and flexible. The importance of youth tourism can be described by the characteristics of youth that they think outside the box, expand the boundaries and experimenting with new ones. The article describes the basic definitions of youth travel, its features and the role of youth tourism as a whole.

Keywords: young tourist, youth, tourism, tourism arrivals, UNWTO, WYSE, youth expenditure, Uzbekistan.

In the last few decades, tourism has developed rapidly and become one of the important sectors of economy. Its total contribution was 10,2 \% of GDP in 2016. International tourism arrivals in 2016 grew by 3.9\% to reach a total of 1235 million worldwide, an increase of 46 million over the previous year. Young tourists play vital role in aforementioned statistics. According to UNWTO statistics around $20 \%$ of the 940 million international tourists travelling the world were travelers ages 15 - 29 in 2010 and this figure increased by 3\% in 2015 . UNWTO forecasts that, by 2020, there will be almost 370 million international youth trips per year. (Figure 1)

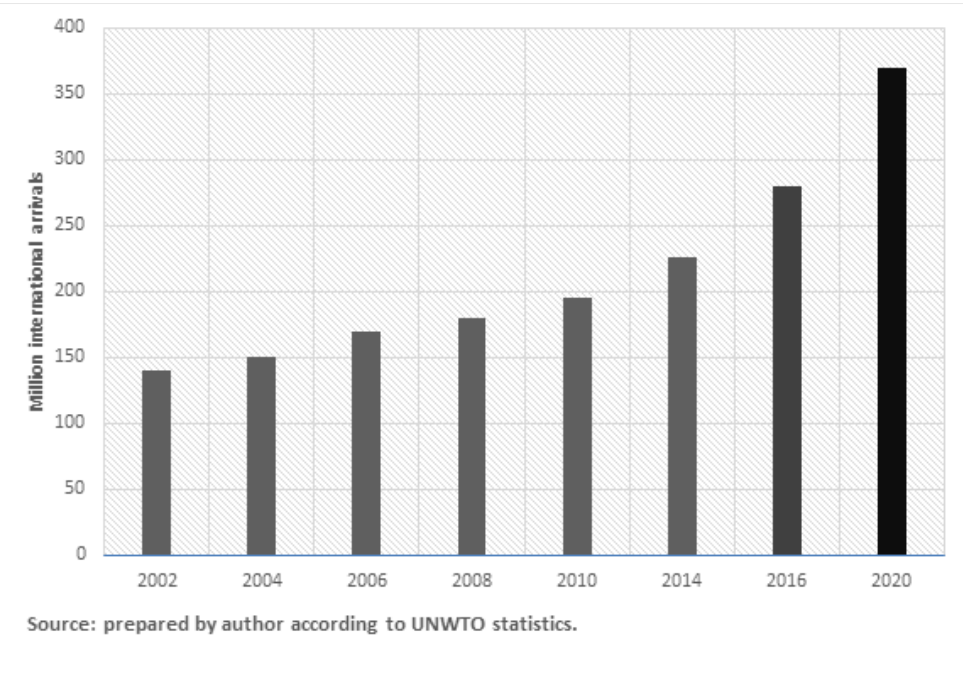

Figure 1. Youth tourism dynamics

\footnotetext{
${ }^{1}$ Mekhrangiz Khusenova, Student of Samarkand Institute of Economics and Service, "Service and tourism" faculty, Uzbekistan.
} 
"Youth tourism" is defined according to World Tourism Organization that: Youth travel includes all independent trips for periods of less than one year by people aged 16-29 which are motivated, in part or in full, by a desire to experience other cultures build life experiences and/or benefit from formal and informal learning opportunities outside one's usual environment.Thesedays many countries and regions have been adopted strategic plans to improve tourism sphere. Uzbekistan has adopted "Strategic development program for the year 2017-2021" and it included the development of tourism. Youth accounted for nearly $60 \%$ of our country's population and our government adopted the law "Youth policy". Uzbekistan Youth Union has "Youth tourism center" that aimed at improving youth tourism. As a future tourists and tourism specialists, the travel of youth is important. Youth tourism has many features that differs from other form of tourism, including:

1.Youth interested in learning and experiencing other cultures and traditions. According to WYSE travel confederation the main purpose of youth travel is relax $\&$ fan that they explore new destinations, meet new people, interact with locals and so on. (Figure 2).
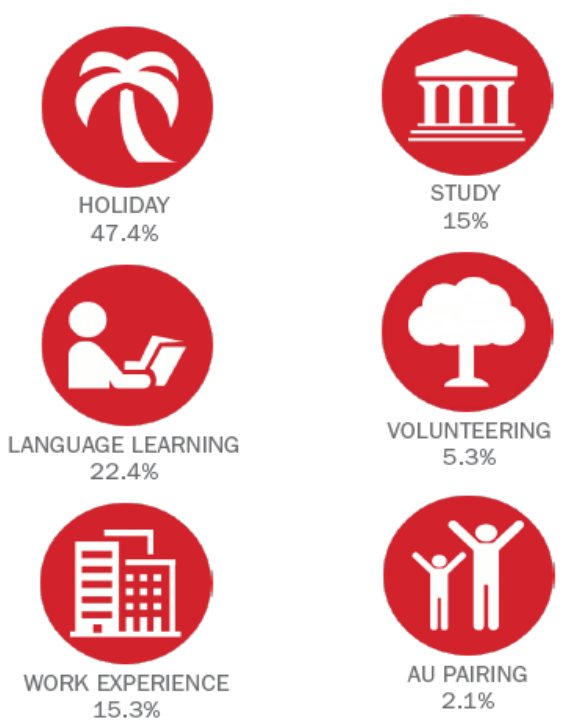

Figure 2. The purpose of the trips taken by the youth. Source: WYSE travel confederation.

NEW HORIZONS III | WORK ABROAD TRAVEL | JANUARY 2015

2. They will respect other nations' cultures and traditions by learning and experiencing them. It helps build friendship among nations and strength peace across the globe.

3.Youth are considered budget limited and for this reason they chose low cost services including form of transport, accommodation, food \& beverage and 
others. During the last decade, the types of accommodation that used by youth changed dramatically. Around 65\% of young tourists preferred hostels in 2013 (Figure 3).

4.

5 .

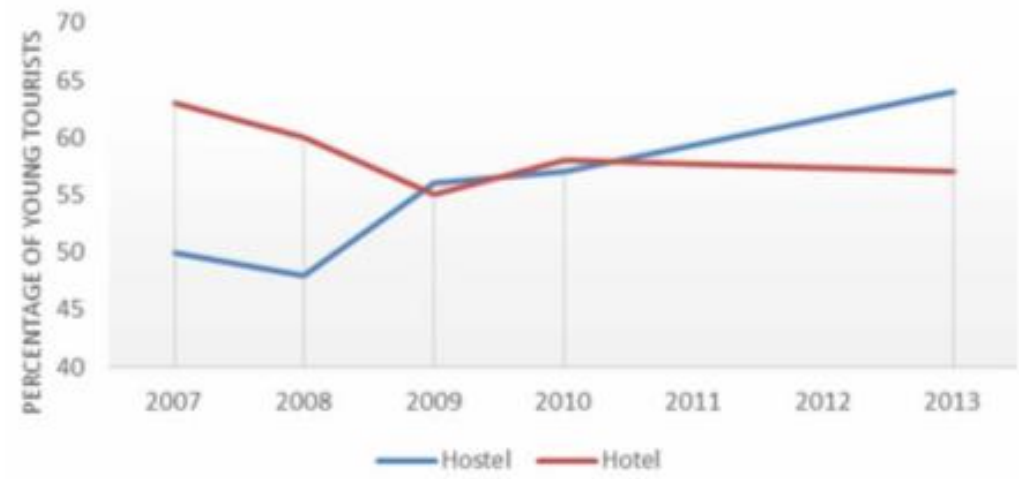

Figure 3. The evolution of the Hotel and Hostel usage among the youth. Sourse: WTSE travel confederation, 2013

6.Young tourists' category buy more local products and services than other tourists. It enables to improve local business industries of a country.

7.Although youth are budget limited, they are rich in time. They want as much experience and trips as possible in their holiday.

8.Young tourists are the pioneers who discover new destinations

9.Young tourists are at the cutting edge of using new technology

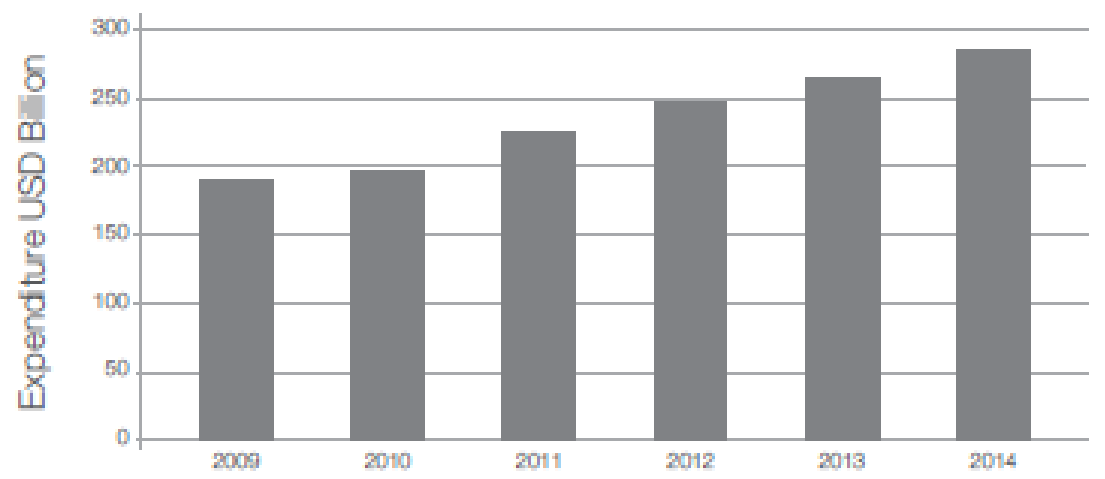

Figure 4. Global youth expenditure

Source: The power of youth travel volume 13, 2016UNWTO, WYSE travel confederation 
10.Young tourists spend more than other tourists. The total expenditure of young tourists accounted for USD 190 billion in 2009 and this figure had rised to USD 286 bilion by 2014 (Figure 4).

UNWTO and WYSE Travel Confederation are convinced that youth travel has moved far beyond its original status as a specialized travel niche to become an important element of the travel mix in any tourism destination. One of the reasons for this is that travel underpins many different aspects of youth lifestyles. For young people:

a.Travel is a form of learning

b.Travel is a way of meeting other people

c.Travel is a way of getting in touch with other cultures

d.Travel is a source of career development

e.Travel is a means of self development

f.Travel is part of their identity - you are where you've been.

In conclusion, the whole world is going to be globalized, that we can easily can access to each other wherever we are. Tourism especially youth tourism is important not only because of economic and social benefits, but also for the future of the world. For the nations and countries that preserve their own heritage, language, culture and traditions.

\section{References}

[1] WTTC economic impact world 2017.

[2] UNWTO Tourism Highlights, 2017 edition.

[3] UNWTO - WYSE 2011, The Power of Youth Travel, Volume 2 Availableat:http://florianopoliscvb.com.br/MyFiles/amreports_vol2_thepowerofyouthtourism_eng_lw.pdf Accessed: 11-02-2014.

[4] WYSE travel confederation. NEW HORIZONS III | WORK ABROAD TRAVEL | JANUARY 2015

[5] The power of youth travel volume 13, 2016UNWTO, WYSE travel confederation

[6] www.lex.uz

[7] www.kun.uz 


\section{ANALYSIS OF FACTORS DETERMINING THE EFFICIENCY OF IMPORT TRANSACTIONS IMPLEMENTED BY A COMPANY UNDER ECONOMIC UNCERTAINTY}

\section{O. Martyanova ${ }^{1}$}

DOI: http://doi.org/10.15350/L_3/3/1

Abstract

The paper presents methodology for evaluation of import transaction efficiency based on the model of indicative figures, which determine economic relevance of carrying out this type of international trade activity with due consideration of the factors focused on accomplishing both operative and strategic import-related goals pursued by an economic entity.

Keywords: analysis, percentage variance graph, import transactions, Markovian processes, ex-ante standard, controlled variance, internal environment factor, efficiency.

One of the consequences of poor barley yield in 2017 is expected to be a pricing pressure on the beer producers [3]. Should beer brewers make changes in the brewery receipts, it will slightly hold down the prices of barley. There will be an increase of winter crop share on the market, as well as an increasing demand for barley varieties previously non-demanded. However, brewers currently have to adapt to the challenging year as high prices for barley will exert a negative impact on the efficiency of those brewery businesses which do not have longterm barley purchase agreements, and fit within the amount allocated for this purpose, which will result in differences between actual and expected results.

Variance analysis is very important for the companies involved in international trade, as these variances influence the company's efficiency. The evaluation of variance in the context of research into efficiency of international transactions is carried out based on exclusion principle, which enables the company to focus on those processes of international trade, where certain actions are required, rather than waste time on something, which doesn't bring the expected outcomes. We believe that the issues requiring thorough exploration in terms of efficiency analysis of international transactions, need a special approach. First of all, the study of these transactions is connected with expenses; secondly, it determines the adequacy of the decision made. Therefore, the decision made on the variance analysis when evaluating the efficiency of international transactions may be schematically represented as follows in Figure 1.

\footnotetext{
1Olga Martyanova, Candidate of Economic Sciences, doctoral candidate the Orel State University of Economics and Trade, Russia.
} 


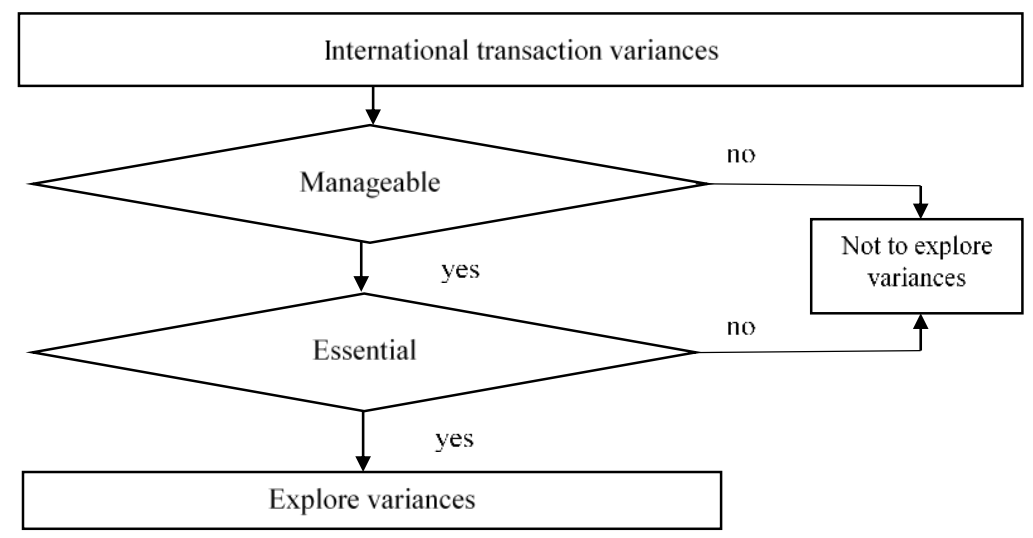

Figure 1. Decision making scheme of evaluating variances when carrying out international transactions Source: compiled by the author

In case the variance is manageable, i.e. emerges as a result of factors controlled by the importer, then these variances should be explored because a company can eliminate these variances or use them in order to enhance the efficiency of its international transactions. Unmanageable variances emerge as a result of factors beyond the company's control, and are not worth examining, because a company may not influence these variances.

In our view, in this case importers face unmanageable variance, i.e. a variance, which emerges as a result of factors beyond the company's control. Therefore, the adverse impact of raw material pricing occurred as a result of an increase in global barley prices cannot be regarded as a variance within the importer's control, and it is not a subject of the importer's responsibility. A manageable variance is, on the contrary, emerging as a result of factors within the control of an economic entity. Thereby, it is necessary to examine such variances under economic uncertainty, as those can be either mitigated or, on the contrary, used for the benefit of the importer.

Thus, the companies should act with due diligence when dealing with variance examination, because it causes extra expenses and concerns the value of the obtained information, which aims to reduce uncertainty in international trade. Before involving a consultancy agency into evaluation of international trade transactions, it is necessary to estimate the amount due for the information provided. A detailed procedure for the estimate of information costs necessary to choose one out of three international suppliers providing international raw materials depending on the market reaction to the changes in international trading activity based on the data provided by the company manufacturing upmarket beer brand is presented in Table 1 .

The analysis of results presented in Table 1 proves that is a company is lacking accurate information, then the optimum solution for this situation will be 
choosing a foreign contract suggested by the Asian supplier, because this supplier is associated with the largest amount of net cash inflow, equalling 739.86 thousand euro.

Table 1

Evaluation of information cost when selecting an import contract

\begin{tabular}{|c|c|c|c|c|}
\hline \multirow[t]{2}{*}{$\begin{array}{l}\text { Market reaction to } \\
\text { the changes of in- } \\
\text { ternational trade } \\
\text { conditions/ Indica- } \\
\text { tor }\end{array}$} & \multirow[t]{2}{*}{$\begin{array}{l}\text { Likelihood of } \\
\text { changes in the } \\
\text { conditions of } \\
\text { international } \\
\text { trade }\end{array}$} & EU supplier & $\begin{array}{l}\text { North Ameri- } \\
\text { can supplier }\end{array}$ & $\begin{array}{l}\text { Asian sup- } \\
\text { plier }\end{array}$ \\
\hline & & \multicolumn{3}{|c|}{ Net cash inflow, thousand euro } \\
\hline Strong & 0.5 & 949.00 & 1131.50 & 1241.00 \\
\hline Moderate & 0.3 & 492.75 & 234.33 & 352.59 \\
\hline Weak & 0.2 & 92.71 & 205.86 & 67.89 \\
\hline \multicolumn{5}{|c|}{ In the absence of accurate information: } \\
\hline $\begin{array}{l}\text { The expected value } \\
\text { of net cash inflow } \\
\text { per year, thousand } \\
\text { euro }\end{array}$ & - & 640.87 & 677.22 & 739.86 \\
\hline \multicolumn{5}{|c|}{ In the presence of accurate information: } \\
\hline $\begin{array}{l}\text { The expected value } \\
\text { of net cash inflow } \\
\text { per year, thousand } \\
\text { euro: }\end{array}$ & - & - & - & - \\
\hline $\begin{array}{l}\text { - strong market } \\
\text { reaction, thousand } \\
\text { euro }\end{array}$ & 0.5 & 474.50 & 565.75 & 620.50 \\
\hline $\begin{array}{l}\text { - moderate mar- } \\
\text { ket reaction, thou- } \\
\text { sand euro }\end{array}$ & 0.3 & 147.83 & 70.30 & 105.78 \\
\hline $\begin{array}{l}\text { - weak market re- } \\
\text { action, thousand } \\
\text { euro }\end{array}$ & 0.2 & 18.54 & 41.17 & 13.58 \\
\hline
\end{tabular}

Source: calculated by the author

Should an importer have accurate information, the situation would be different. Thus, if the examination predicts a strong market reaction to the change of international trade conditions, then it would be reasonable to select an Asian importer. In this case the net cash inflow will amount to 620.50 thousand euro per year. Provided the market reaction to changes is moderate, it is advisable to select a contract offered by the EU supplier, which will ensure an annual cash inflow in the amount of 147.83 thousand euro. If examination predicts a weak market reaction, then it is recommended to make a contract with a North American supplier, as this option will ensure net cash inflow in the amount of 41.17 thousand euro. Thus, once the expected value of net cash inflow equals to 809.5 thou- 
sand euro, provided there is accurate information, the cost of this accurate information will equal to 96.64 thousand euro. This is the maximum amount due to payment by the company to the consultancy agency for this information.

In order to give an adequate evaluation of the efficiency of international transactions in line with the operating conditions of the company, the company should separately consider operational and expected variances, as it will enable the company to obtain the benchmarks in comparison with the original criteria. This is because operational variances, unlike the expected ones, are based on revised standards and reflect the result level reached by an importer when carrying out international transactions. Planned variances emerge when, in the light of the circumstances becoming known, the original standards turn to be inadequate.

Distinguishing between planned and operating variances enable a company to identify their origin. Thus, if a production department is unable to influence the planned variances, therefore, cannot be responsible for them, this means that the time spent by the department on examining these variances will not bring any benefit. Planned variances may emerge as a result of setting incorrect benchmarks by the budget department, hence the department forming the budget based on ex-ante standards should be responsible for those.

In order to have a clear idea on the efficiency of international transactions over the period under study it is necessary to determine the cause of variances, which may imply either using inadequate standards or their inefficient application. So as to define the causes of variances, the importer should develop a new revised plan with ex-post standards, based on the estimates, which were revised after the budget was adopted and the primary standards were determined. In our view, it is important for the standards to take into consideration the market tendencies in the sphere of import known at the time of their determination, as this will enable the company management to avoid the emergence of adverse standards and suggests the effectiveness of standard development system.

The calculation of the planned variances may be carried out using the methods of varying difficulty. In our view, in order to solve this problem, an importer should refer to the method which implies carrying out only three following steps:

Step 1: calculate a gap between ex-ante and ex-post standards.

Step 2: form a planning variance, emerging as a result of calculations carried out when implementing step 1.

Step 3: calculate operating variances based on ex-post standards.

We believe that the simplicity of the method is its major advantage, as the results obtained raise a company's motivation of referring to it when analyzing effective import transactions.

Given that a variance analysis is aimed at improving the efficiency of import transaction management, it is necessary to establish criteria making it possible to make a decision on the relevance of their examination. In our view, these criteria should be developed based on the factors, which can be taken into consideration when making such a decision: the amount of variance, likelihood that a variance is manageable; correlation between variances; and a type of the stand- 
ards applied. Pro arguments for the use of these factors when creating a benchmarking system for evaluating the efficiency of import transactions prove, there is no point in examining minor variances or variances, which exert minimum impact on the overall result. Therefore, an importer can be recommended to set a criterion according to which any variance exceeding the standard costs by $5 \%$ should be thoroughly analysed. A different approach can be used when forming a criterion: first it is necessary to determine the reference values and if a variance value exceeds the set limit, it should be examined.

At the same time, we believe it is irrelevant to analyse variances which are regarded as circumstances that a company cannot change, unmanageable variances will remain the same, even if there is a detailed analysis on the reasons behind these variances. Thus, it is more difficult for a beer importer to control the variance on raw material cost in comparison with the variance on the use of this raw material. It is so because cost variance is mainly determined by the external factors, which make it unmanageable. However, the cost variance on raw material may also be caused by inefficient policy of a company regarding procurement. In any case, until variances are analysed, the source of their occurrence will remain unknown.

In our opinion, the importer should focus on the variances, which are really important and can be changed. In order to do so, it is necessary to estimate possible analysis costs and compare them with the expenses incurred by a company if these variances will continue into the future.

Correlation of variances is also an issue in import transactions as adverse variances of one process may be correlated with the favourable variances of another process. When an importer purchases cheap raw material from an international supplier, on the one hand it ensures favourable variances in terms of pricing, on the other hand, the quality of cheap raw material might be lower, therefore more difficult to process, which might result in adverse variances in terms of raw material use and performance.

When evaluating the efficiency of import transactions it is important to bear in mind the type of the standards used. Even provided the standards are ideally developed, there are variance risks of inevitable losses. For this reason, it is important for the company to define the level of expected variances when carrying out import transactions, i.e. such value of adverse variances, which would be adequate for a company. But carrying out these calculations needs taking into consideration inflation, upward pricing tendency, which can counter-balance positive price variances occurring at the beginning of the year to their unfavourable variances at the end, when the effective prices will be on the increase if the standard price is established as a mean annual price. Thus, the set criteria based on the above stated factors allow to make an adequate decision with regard to variance analysis in international trade.

One of the factors taken into consideration when making a decision whether the variance analysis is necessary or not is its amount. However, in some cases an importer finds it difficult to evaluate the scale or tendency of variances provided they are represented in absolute values. In such cases a company may be recommended to use percentage variance graphs in the format, which facilitates 
data interpretation and allows to determine future trends in the sphere of import. In order to reveal tendencies in up-market beer production based on imported raw material, let us provide an evaluation of variances followed by the representation of their temporal dynamics, necessary to make a decision on changing raw material purchasing policy due to fluctuations of beer output caused by shifting patters in customer demand. For the purpose of our research we used the data available from the annual reports and data publications of an industrial company. The results of percentage variation calculations inclusive of expenditures on purchasing an upmarket ingredient as well as the data on production volume and fixed variations of raw material expenditures over the 4 month period of 2017 are provided in Table 2.

Table 2

Evaluation of percentage variances in terms of price and volume of the material used over the period from September 2017 to December 2017

\begin{tabular}{|c|c|c|c|c|}
\hline \multirow[t]{2}{*}{ Parameter } & \multicolumn{4}{|c|}{ Four-month period of 2017} \\
\hline & September & October & November & December \\
\hline $\begin{array}{l}\text { Purchase } \\
\text { amount, kg }\end{array}$ & 4234.0 & 1803.1 & 3358.0 & 2263.0 \\
\hline $\begin{array}{l}\text { Price per unit, } \\
\text { euro }\end{array}$ & 25.33 & 25.33 & 25.33 & 25.33 \\
\hline $\begin{array}{l}\text { Raw material } \\
\text { price variance, } \\
\text { euro }\end{array}$ & $4445.70 \quad(n)$ & 1514.75 (n) & $2350.60 \quad(n)$ & $1109.60 \quad(n)$ \\
\hline $\begin{array}{l}\text { Variance in the } \\
\text { volume of used } \\
\text { raw material, } \\
\text { euro }\end{array}$ & $5927.60 \quad(n)$ & $2146.20 \quad(n)$ & $3055.05 \quad(n)$ & $1584.10 \quad(\mathrm{n})$ \\
\hline $\begin{array}{l}\text { Standard cost of } \\
\text { materials, euro }\end{array}$ & 107251.45 & 45674.33 & 85061.50 & 57324.05 \\
\hline $\begin{array}{l}\text { Price variance } \\
\text { calculated as a } \\
\text { percentage of ag- } \\
\text { gregate standard } \\
\text { cost of material, } \\
\%\end{array}$ & $4 \quad(n)$ & $3 \quad$ (n) & $3 \quad(n)$ & $2 \quad(n)$ \\
\hline $\begin{array}{l}\text { Volume variance } \\
\text { of material used } \\
\text { calculated as a } \\
\text { percentage of ag- } \\
\text { gregate standard } \\
\text { cost of material, } \\
\%\end{array}$ & $6 \quad(n)$ & $5 \quad$ (n) & $4 \quad(n)$ & (n) \\
\hline
\end{tabular}

Source: Compiled by the author

Graphic interpretation of the obtained results is provided in Figure 2. It shows that the graph in each variance demonstrates a clear trend. It should be noted that this trend is not clearly visible when considering data provided in ab- 
solute values. The analysis of the graph proves that in September 2017 the ingredient purchased abroad was $4 \%$ more expensive than the standard cost of raw material. This might be the reason of its unfavourable variance in terms of its use, which comprised $6 \%$ of the aggregate standard raw material cost necessary for the actual production.

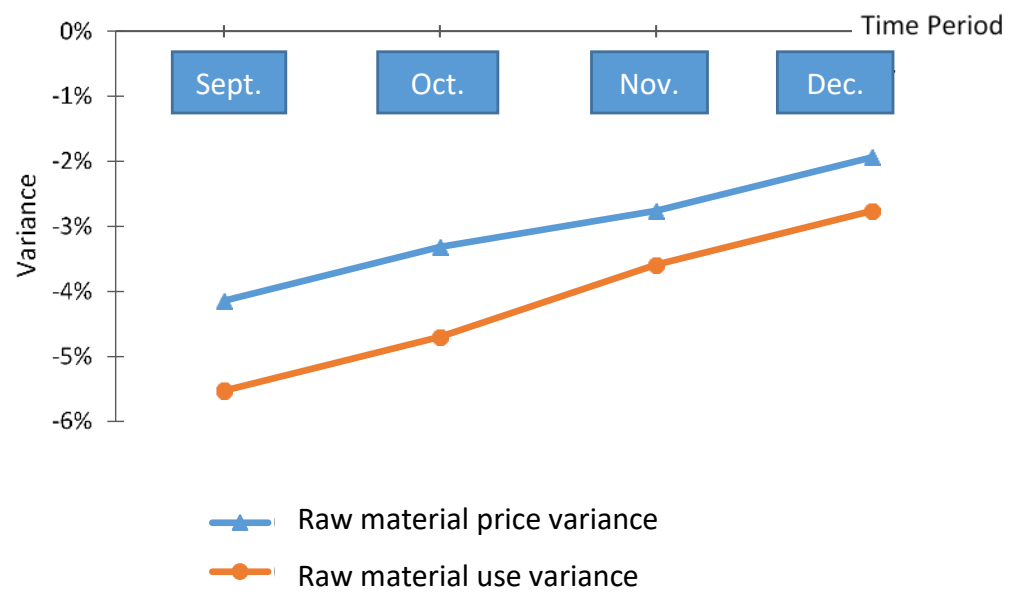

Figure 2. Graphic interpretation of the obtained results

Research into variance changes proves that with the decrease in raw material price, which in its turn decreased the unfavourable percentage price variance, the use of an ingredient in terms of its volume was close to its standard value, thus reducing the percentage variance of raw material usage. The analysis carried out enables us to make a conclusion that due to changes in both variances approaching zero, a more thorough analysis is not required on this stage. However, we believe, if we operated variances represented in absolute values only, it would be difficult to come to this conclusion.

Exploring variances we cannot ignore the reasons of their emergence, one of which, in our view, being uncontrolled factors. When setting a standard it is necessary to choose one representative value of an indicator, whereas there is a certain range of possible outcomes, even when international transactions are implemented under control.

This should be taken into consideration when exploring variances as an integral part of efficiency concept of international transactions.

In our view, under economic uncertainty, the standard that meets certain parameters acceptable for a beer manufacturing company, should be regarded as a range of possible values of an indicator, rather than a parameter expressed in one value. The range itself may be predicted, however, it is impossible to predict the exact indicator value within this range. And yet "making well-grounded and timely managerial decisions is impossible without accurate information" (Vasilchik, 2013 p.8). This task can be solved using Markovian processes, which can 
be demonstrated by the example below. A company producing upmarket beer has to determine the standard price of beer produced from imported raw material. Information obtained by a business entity when exploring the market of premium class beer indicated that the conditions of contracts between an importer and a foreign supplier allow to set a price within the range from 13 to 27 euro per one litre of beer.

Let us analyse system $S$, which refers to one litre of upmarket beer, and let us evaluate those conditions of this system, which are characterised by the market price of beer within the following ranges:

$s_{1}$ - from 13 еиго до 16 еurо;

$s_{2}$ - from 16 еuго до 22 euro;

$s_{3}$ - from 22 еurо до 24 еuro;

$s_{4}$ - от 24 еurо до 27 euro.

The market price of one litre of upmarket beer depends only on its current price at this point of time. The price of beer may change at any random moment as a result of accidental impact of the market. System $S$ transfer from one conditions into another occurs with probability densities fixed in time and values presented in Matrix (1):

$$
\rho=\left(\begin{array}{llll}
0 & 4 & 3 & 1 \\
2 & 0 & 1 & 7 \\
4 & 0 & 0 & 3 \\
6 & 1 & 2 & 0
\end{array}\right) .
$$

Based on the primary data, system $S$ features a discrete homogeneous continuous-time Markovian process. It means that the flows of events fostering system $S$ to transfer from one state into another are simple. The marked state graph is provided in Figure 3.

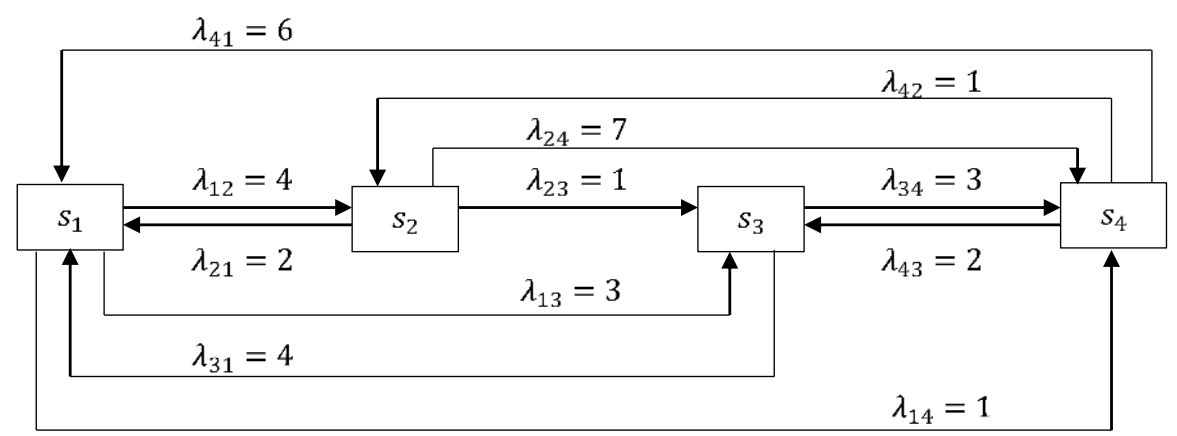

Figure 3. State graph of the system under study 
Graph analysis proves that system $S$ may transfer from one state into another in a finite number of steps, which means the system is ergodic. It is proved in [1 p. 115] that if the number of states of system $S$ is finite, this system is ergodic and all flows of events causing system $S$ to transfer from one state into another are simple, then there are final probabilities of states $\left(p_{i}\right)$ defined as follows:

$$
p_{i}=\lim _{t \rightarrow+\infty} p_{i}(t), i=1, \ldots, n
$$

where $p_{i}(t)$ - probability of state $s_{i}$ of system $S$ at the moment $t$.

In order to determine final probabilities there are good reasons to use the system of Kolmogorov differential equations, which is represented as follows [1. p.40]:

$$
\frac{d p_{i}(t)}{d t}=-\left(\sum_{j=1}^{n} \lambda_{i j}\right) p_{i}(t)+\sum_{j=1}^{n} \lambda_{i j} p_{j}(t), \quad i=1, \ldots, n ; \quad t \geq 0 .
$$

If in equation (3) we proceed to the limit under $t \rightarrow+\infty$, then it rearranges into the system of homogeneous algebraic linear equations in the $n$ unknowns of $p_{i}, i=1, \ldots, n$, shown as below [2 p. 125]

$$
-\left(\sum_{j=1}^{n} \lambda_{i j}\right) p_{i}+\sum_{j=1}^{n} \lambda_{i j} p_{j}=0, \quad i=1, \ldots, n
$$

because the probability of continuous random variable $p_{i}(t)$ under $t \rightarrow+\infty$ converge to contstant value $p_{i}$, while the derivative of a constant value equals zero. In view of the foregoing considerations, let us form a system of equations:

$$
\left\{\begin{array}{c}
-8 p_{1}+2 p_{2}+4 p_{3}+6 p_{4}=0 \\
4 p_{1}-10 p_{2}+p_{4}=0 \\
3 p_{1}+p_{2}-7 p_{3}+2 p_{4}=0 \\
p_{1}+7 p_{2}+3 p_{3}-9 p_{4}=0
\end{array}\right.
$$

By transforming the system of equations (5) we will obtain

$$
\left\{\begin{array}{l}
-8 p_{1}+2 p_{2}+4 p_{3}+6 p_{4}=0 \\
p_{3}=0.98 p_{4} \\
p_{2}=-0.8 p_{3}+1.45 p_{4} \\
p_{1}=2.6 p_{3}-1.15 p_{4}
\end{array}\right.
$$

or

$$
\left\{\begin{array}{c}
-8 p_{1}+2 p_{2}+4 p_{3}+6 p_{4}=0 ; \\
p_{3}=0.98 p_{4} ; \\
p_{2}=0.67 p_{4} ; \\
p_{1}=1.4 p_{4} .
\end{array}\right.
$$

Therefore, the general solution of system (5), depending on one arbitrary parameter $p_{3} \in[0,1]$, is vector

$$
\left(p_{1}=1.4 p_{4} ; \quad p_{2}=0.67 p_{4} ; \quad p_{3}=0.98 p_{4} ; \quad p_{4}\right) .
$$

By changing the first equation with a standard condition we will obtain a system, which makes it possible from the whole set of particular solutions to find the one meeting the required conditions:

where

$$
\left\{\begin{array}{l}
p_{1}+p_{2}+p_{3}+p_{4}=0 \\
p_{3}=0.98 p_{4} \\
p_{2}=0.67 p_{4} \\
p_{1}=1.4 p_{4}
\end{array}\right.
$$




$$
\left\{\begin{array}{l}
p_{1}=0.35 \\
p_{2}=0.17 \\
p_{3}=0.23 \\
p_{4}=0.25
\end{array}\right.
$$

As a result of calculations carried out it is possible to predict the market price of premium class beer, which means that after allowing sufficient time, there is a high probability that the price per one litre of upmarket beer will be within the range from 13 euro to 16 euro. That is why, an importer can refer to the price range from 13 to 16 euro per one litre of upmarket beer, thus exposing itself to a minimum risk level.

Thus, systematization of the findings carried out allows us to draw the following conclusions:

1. Variance analysis of actual results from the expected ones makes it possible to determine the progress of the company in its pursue of its goals, determined by international trade strategy, including import. Therefore, the process of variance analysis contains nothing to make it incompatible with the concept of efficiency enhancement of international trade transactions. Variance analysis is aimed at enhancing the efficiency of import operations, since it provides an increased company's focus on those processes requiring taking measures and not to waste time on those processes, where the results are in line with expectations.

2. A company should analyse only variances which are appropriate for the exploration. Therefore, for the purpose of analysis of different types of cost variances when carrying out import transactions, it is necessary to use the set criteria based on the factors due for consideration when making such a decision. It was determined that in order to identify trends in variance change it is relevant to use percentage variance graphs, which make it possible to represent them in temporal dynamics.

3. The revealed distinctive characteristics of exploring differences between actual and expected results when carrying out import transactions enabled us to formulate the principles, characteristic for the analysis of this type of international trade of a company. Application of these principles offers an opportunity to carry out a comprehensive analysis and systematization of internal environment factors, to define the procedure of an importer's actions, to form an information base of the subject under study, to develop methodology for variance analysis for international trade transactions.

4. The results obtained proved that in order to enhance the efficiency of international transactions, while analysing variances it is possible to apply such probability modelling as Markovian processes. These processes make it possible to predict the range of probable indicator changes under economic uncertainty, which allows avoiding inaccuracy in setting standards.

\section{References:}

[1] Labsker L.G. Probabilistic modelling in the financial-economic field [Text]: the Textbook / L.G. Labsker. - The second edition. - M: INFRA-M, 2014. - pp. 172.

[2] Martyanova O.V. Model of the impact assessment price risks in the conditions uncertainty on efficiency of the foreign trade business activities with use of hedging and 
markov processes [Text] / O.V. Martyanova // Audit and financial analysis. - 2016. № 4. - P. 113-126.

[3] Producers of malt and brewers will shall "adapt by difficult year [Electronic resource]. URL: http://e-malt.ru/News.asp?Command=ArticleShow\&ArticleID $=4674$

[4] Vasilchuk O. I. Use of the management decisions [Text] this managerial accounting in case of acceptance / O. I. Vasilchuk // The Karelian scientific magazine. - 2013. - № 2. - P. 8-10. 


\title{
CONTROL SUBMECHANISM OF MECHANISM OF ENERGY SAVING MANAGEMENT IN THE SYSTEM OF HIGHER EDUCATION INSTITUTIONS
}

\author{
O. Shevchenko ${ }^{1}$
}

DOI: http://doi.org/10.15350/L_3/3/2

Abstract

The definition of control submachinism as a set of functions of control and monitoring of the activity of energy saving management entity at different levels is substantiated, which is realized through the formation of an information database on the effectiveness of the MESMSHEI and the energy conservation policy implementation.

In the structure of the control submechanism MESMSHEI, which is realized by State Energy Efficiency, five blocks are distinguished: 1) involvement in energy saving activities; 2) state registration; 3) accreditation and implementation of energy saving activity; 4) monitoring in the field of energy saving; 5) control in the field of energy saving - by which tasks and functions of energy saving are distributed.

The peculiarities of implementation of performance-contracting concept in Ukraine are analyzed, the features of the control organization over using energy service contracts are determined, that allowes to distinguish five main blocks. The study of the interaction of subjects and objects of energy conservation within the energy service reveales the role of individual subjects in adoption, approval, regulation of the implementation of management decisions. The assorting of the control submechanism units in the implementation of the energy service technology confirmes the compliance of the control structure with the control submechanism, which is being implemented by the State Department of Energy Efficiency in the process of fulfilling the main tasks and functions, which makes it possible to improve and systematize the legislative and normative provision of energy saving.

Keywords: energy saving, control submachinism, mechanism of energy saving management in the system of higher education institutions, performancecontract.

Постановка проблемы и ее связь с важными научными и практическими задачами. В Украине в результате завершения реструктуризации энергетических компаний и становления энергорынков возникла энергетическая неопределенность. Она генерирует угрозы деятельности для субъектов энергетики: изменчивость розничного потребления, расширение при-

\footnotetext{
${ }^{1}$ Oleg Shevchenko, Director of the Project Office, Kiev National University of Technology and Design, Kiev, Ukraine.
} 
менения «зеленого тарифа» на генерацию электроэнергии из возобновляемых источников, неплатежеспособность потребителей, ограничение дотирования и субсидирования населения и бюджетных учреждений, развитие генерации электроэнергии из возобновляемых источников энергоресурсов, - которые перекладываются на потребителей путем повышения тарифов и повышения доли инвестиционной составляющей в них .

В последние годы существенно выросли расходы учреждений высшего образования на энергопотребление за счет отмены дифференцированной системы тарифов. Из-за недофинансирования из бюджета высшие учебные заведения вынуждены использовать собственные поступления от хозяйственной деятельности для оплаты услуг по энергоснабжению и теплоснабжению. При таких условиях эффективность энергосбережения в вузе приобретает ключевое значение для успешного его существования, а результаты определяются эффективностью контрольной составляющей механизма управления энергосбережением.

Похожая ситуация в 90-х годах XX века стимулировала энергетические компании США и Западной Европы искать новые возможности расширения спектра предоставления и охвата услугами потребителей за счет инвестирования в энергосбережение и энергоэффективность потребления. Для решения поставленных задач было использовано технологию перфоманс-контрактинга путем создания дочерних предприятий для инвестирования в внедрение энергосберегающих мероприятий в образовательной сфере.

Анализ последних публикаций по проблеме исследования. В Ежегодном послании Президента Украины к Верховной Раде Украины «О внутреннем и внешнем положении Украины в 2015 году» отмечается необходимость конвергенции науки, образования и предпринимательства, а государственная политика должна способствовать этому, стимулируя расширение возможностей финансирования инновационных разработок и их внедрения [1]. К приоритетным направлениям государственной политики отнесены энергосбережение и энергоэффективность.

Результаты изучения теоретических и практических проблем энергосбережения отражены в работах А. Амоши, А. Бауэна, А. Вигдорчик, К. Гилингема, Л. Головановой, Г. Грубы, К. Демирчана, С. Денисюка, Р. Джемилева, Г. Дзянь, П. Дияка, Г. Дугинец, П. Дьюти, И. Зарембы, М. Ковалко, 0. Ливинского, Л. Лум, И. Мартинсона, В. Микитенко, Я. Николайдиса, Ю. Орловской, Д. Оуянг, К. Палмера, П. Пирсона, О. Поповченко, О. Праховика, В. резво, Ж. Ричарда, К. Ромамерти, Т. Салашенко, Л. Саркисян, Ю. Свирчевский, О. Ставицкой, О. Суходоли, В. Черниковой, А. Шидловского и других. Исследованные научные работы по энергосбережению рассматривают его как процесс сохранения энергетических ресурсов, характеризуют концепции внедрения энергосберегающих технологий в процессе строительства и реконструкции зданий и сооружений или отдельные аспекты применения инструментов и механизмов энергосбережения в Украине.

Учитывая результаты известных исследований, дополнительного изучения заслуживает контрольный подмеханизм механизма управления 
энергосбережением в системе высших учебных заведений, ибо обеспечивает регламентацию, регулирование, надзор и возможность внедрения новых инструментов для совершенствования организации указанного аспекта деятельности вуза за счет систематизации.

Цель исследования предполагает определение содержания, строения, особенностей действия контрольного подмеханизма механизма управления энергосбережением в системе высших учебных заведений и поиск направлений его совершенствования.

Изложение основных результатов иследования и их обоснование. Учитывая особенности дефиниции категорий «механизм управления» и «механизм государственного управления» предлагаем рассматривать контрольный подмеханизм как совокупность функций контроля и мониторинга деятельности субъектов управления энергосбережением разных уровней, который реализуется через формирование информационной базы данных об эффективности функционирования МУЕСВУЗ и реализацию политики энергосбережения.

Контроль и надзор в сфере энергосбережения обеспечивают Кабинет Министров Украины, НКРЕКП, Госэнергоэффективности.

НКРЕКП осуществляет содействие внедрению мероприятий по энергоэффективности, увеличению доли производства энергии из возобновляемых источников энергии и защиты окружающей среды; устанавливает минимальные стандарты и требования к качеству обслуживания потребителей и поставки природного газа, электрической и тепловой энергии, осуществляет мониторинг их соблюдения; обеспечивает в соответствии с законодательством доступ потребителей к информации о ценах/тарифах в сферах снабжения электрической энергией, природным газом, в сферах теплоснабжения, централизованного водоснабжения и водоотведения; проводит консультации с Секретариатом Энергетического Сообщества с целью получения выводов по применению европейского энергетического права; осуществляет государственный контроль за соблюдением субъектами хозяйствования, осуществляющими деятельность в сферах энергетики и коммунальных услуг, законодательства в соответствующих сферах и лицензионных условий путем проведения плановых и внеплановых выездных, а также невыездных проверок в соответствии с утвержденными порядками контроля; осуществляет мониторинг оптовых и розничных цен на товары (услуги) на рынках в сферах энергетики и коммунальных услуг; мониторинг отсутствия проявлений перекрестного субсидирования между различными видами деятельности, категориями потребителей (заказчиков) на рынках в сферах энергетики и коммунальных услуг; оценку разработки и реализации инвестиционных программ и мероприятий по инвестиционному планированию в отношении операторов систем передачи, газотранспортной системы в краткосрочной и долгосрочной перспективе с целью повышения эффективности работы систем и содействия рыночной интеграции; мониторинг инвестиций в генерирующие мощности с целью обеспечения безопасности поставок электрической энергии и применения условий для присоединения к сетям новых генерирующих 
мощностей с должным учетом затрат и выгод, связанных с различными технологиями в использовании возобновляемых источников энергии, а также с распределенной генерацией и комбинированным производством тепловой и электрической энергии (когенерацией) и т.д. [2].

Государственная инспекция по энергетическому надзору Украины осуществляет контроль за соответствием новых и реконструированных электрических и тепловых установок и сетей техническим условиям, нормам, правилам и стандартам, обеспечивает подтверждение их готовности к работе; принимает участие в работе комиссий по приемке в промышленную эксплуатацию автоматизированных систем коммерческого учета энергии на установках субъектов электроэнергетики и объектов в сфере теплоснабжения; подготовку предложений по пересмотру нормативно-технической документации на энергетическое оборудование в случае его несоответствия требованиям Правил устройства электроустановок, Правил технической эксплуатации электроустановок потребителей, Правил технической эксплуатации систем теплоснабжения коммунальной энергетики, Правил эксплуатации тепловых установок и тепловых сетей; участие в случае необходимости в проведении экспертизы электро- и теплотехнической частей проектов строительства и реконструкции объектов заказчиков на соответствие требованиям; надзор за обеспечением надлежащего оперативно-диспетчерского управления энергохозяйством потребителей энергии и т.д. [3].

Деятельность Госэнергоэффективности в сфере энергосбережения, как центрального органа исполнительной власти, определяется и координируется через вице-премьер-министра Украины - Министра регионального развития, строительства и жилищно-коммунального хозяйства Кабинетом Министров Украины и направлена на реализацию государственной политики по обеспечению эффективного использования топливно энергетических ресурсов, энергосбережения, расширение использования возобновляемых источников энергии и альтернативных видов топлива.

Государственное агентство по энергоэффективности и энергосбережению Украины осуществляет контроль и мониторинг в разрезе определенных задач его деятельности, поэтому можно выделить следующие блоки контрольного подмеханизма управления энергосбережением:

Блок 1 «Привлечение к деятельности по энергосбережению» предусматривает: 1) анализ и обобщение практики применения законодательства по вопросам энергоэффективности и энергосбережения и разработки предложений по совершенствованию регуляторной деятельности (финансового и нормативного регулирования); 2) подготовку международных договоров Украины и обеспечивает их выполнение в соответствии с законодательством; заключает международные договоры Украины межведомственного характера; осуществляет адаптацию национального законодательства к законодательству ЕС; выполнение мероприятий по имплементации в национальное законодательство положений международных договоров, стороной которых является Украина; международное сотрудничес- 
тво; 3) участие в пределах своих полномочий в налаживании сотрудничества Украины с Европейским Союзом, Европейским Сообществом по атомной энергии и их государствами-членами в сфере эффективного использования топливно-энергетических ресурсов, энергосбережения, возобновляемых источников энергии и альтернативных видов топлива; 4) информационную деятельность по популяризации экономических, экологических и социальных преимуществ эффективного использования топливно-энергетических ресурсов, энергосбережения, возобновляемых источников энергии и альтернативных видов топлива; 5) организацию обучения и подготовку предложений по совершенствованию системы подготовки и переподготовки специалистов в сфере эффективного использования топливно-энергетических ресурсов, энергосбережения, возобновляемых источников энергии и альтернативных видов топлива; 6) разработку предложений по стимулированию энергосбережения, эффективного использования топливно-энергетических ресурсов, возобновляемых источников энергии и альтернативных видов топлива и осуществление мониторинга их применения; 7) содействие организации публичных закупок энергосервиса установлением и регламентацией процедуры открытых торгов или переговорной процедуры закупки согласно действующего порядка [4] закупок услуг, с учетом особенностей технологии энергосервиса;

Блок 2 «Государственная регистрация» воплощается в: 1) ведение Государственного реестра предприятий, учреждений, организаций, осуществляющих разработку, внедрение и использование энергоэффективных мероприятий и энергоэффективных проектов; 2) ведение реестра альтернативных видов топлива и государственного реестра производителей жидких биологических видов топлива и биогазовых;

Блок 3 «Аккредитация и реализация деятельности по энергосбережению» заключается в следующем: 1) реализации государственно-частного партнерства в сфере эффективного использования топливно-энергетических ресурсов, энергосбережения, возобновляемых источников энергии и альтернативных видов топлива; 2) документальном удостоверении принадлежности топлива к альтернативному; 3) квалификации когенерационных установок; 4) обеспечении функционирования системы энергетической маркировки электрооборудования бытового назначения; 5) создании фондов государственной поддержки мероприятий в сфере эффективного использования топливно-энергетических ресурсов, энергосбережения, возобновляемых источников энергии и альтернативных видов топлива;

Блок 4 «Мониторинг в сфере энергосбережения» включает: 1) создание и функционирование государственной системы мониторинга показателей энергетического баланса Украины; 2) мониторинг эффективности использованием топливно-энергетических ресурсов; 3) энергетический аудит; 4) анализ потенциала повышения энергетической эффективности зданий; 5) мониторинг энергосервисных услуг и их эффективности; 
Блок 5 «Контроль в сфере энергосбережения» осуществляется через: 1) разработку, согласование с НКРЕКП и осуществления контроля за выполнением государственных целевых программ в сфере эффективного использования топливно-энергетических ресурсов, энергосбережения, возобновляемых источников энергии и альтернативных видов топлива, согласовывает отраслевые, региональные и местные программы в этой сфере; 2) государственную экспертизу по энергосбережению; 3) введение энергетического менеджмента; 4) разработку и контроль соблюдения государственных норм, правил, технических регламентов и стандартов в сфере эффективного использования топливно-энергетических ресурсов, энергосбережения; 5) разработку критериев устойчивости для жидкого и газообразного топлива производится из биомассы; 6) выработку технических требований к производству и использованию биотоплива и биожидкостей с сокращением объемов выбросов парниковых газов.

Госэнергоэффективности осуществляет выдачу приказов организационно-распорядительного характера, организовывает и контролирует их выполнение [5].

В рамках первого блока «Привлечение к деятельности по энергосбережению» осуществляется разработка и выполнение Национального плана действий по энергоэффективности до 2020 года, Национального плана действий по возобновляемой энергетике до 2020 года, планов мероприятий по транспозиции европейских директив в сферах энергоэффективности и возобновляемой энергетики, подготовка регламентов в сферах энергоэффективности и энергосбережения, Плана мероприятий по внедрению систем энергоменеджмента в бюджетных учреждениях, Дорожной карты нормативно-правового обеспечения развития сфер энергоэффективности и возобновляемой энергетики.

Государственная регистрация предусматривает обнародование информации об иностранных партнерах Госэнергоэффективностью; ведение реестра альтернативных видов топлива; предоставление гарантий происхождения энергии, произведенной из ВИЭ и в процессе когенерации; создание и ведение базы данных инвестиционных проектов и технических решений; ведение реестра когенерационных установок; регистрацию эско-компаний, договоров и т.

Согласно блока «Аккредитация и реализация деятельности по энергосбережению» Министерства и другие центральные органы исполнительной власти разрабатывают и согласовывают с Госэнергоэффективностью программы уменьшения потребления энергоресурсов бюджетными учреждениями путем их рационального использования. Госэнергоэффективности методологически обеспечивает разработку отраслевых программ повышения энергоэффективности и программ уменьшения потребления энергоресурсов бюджетными учреждениями и разрабатывает проект Государственной целевой экономической программы энергоэффективности, учитывая содержание положений отраслевых программ повышения энергоэффективности. 
Блок 4 «Мониторинг в сфере энергосбережения» предусматривает построение карты теплых кредитов, позволяет установить интенсивность внедрения энергосбережения в бюджетной и жилищной сферах; введение энергетической сертификации зданий; осуществление энергетического аудита.

Министерства и другие центральные органы исполнительной власти с 2010 года до 10 числа второго месяца после завершения полугодия, направляют в Госэнергоэффективности информацию о выполнении отраслевых программ повышения энергоэффективности и программ уменьшения потребления энергоресурсов бюджетными учреждениями согласно утвержденным Агентством формам для ее обработки и доведения до Кабинета Министров Украины до 25 числа месяца ее сбора [6].

Блок 5 «Контроль в сфере энергосбережения» осуществляется через проведение энергетического аудита и создания эффективных систем управления и средств контроля за энергосбережением, путем использования системы государственных стандартов в сфере энергосбережения.

В рамках этого блока осуществляется государственная экспертиза по энергосбережению проектов развития отраслей народного хозяйства, территориальных схем энергообеспечения, энерготехнологической части технико-экономических обоснований и проектов строительства новых и расширения (реконструкции, технического обеспечения, модернизации) действующих объектов и предприятий при годовом потреблении ТЭР в тысячу и более тонн в пересчете на условное топливо - по обращению заказчика для предоставления преференций за счет бюджетных средств, проектов инструкций методических и нормативно-технических актов, строительных норм и правил, документации на создание и приобретение новой энергоемкой техники, другие документы и материалы, регламентирующие деятельность в сфере энергосбережения.

Заключение государственной экспертизы по энергосбережению является обязательным для применения льгот согласно действующему налоговому и таможенному законодательству, приоритетного кредитования мероприятий по обеспечению рационального использования и экономии топливно-энергетических ресурсов, получения безвозвратного ассигнования, целевых государственных и других субсидий, субвенций, дотаций для осуществления мероприятий по обеспечению энергосбережения за счет бюджетных средств [7].

При введении в вузах технологии комбинированного производства электрической и тепловой энергии или преобразования сбросного энергетического потенциала технологических процессов в электрическую и тепловую энергию производится квалификация когенерационной установки, которая заключается в определении Госэнергоэффективностью соответствия условий и показателей эксплуатации когенерационной установки действующим требованиям или квалификационным показателям [8, с. 2]. Использование когенерации требует лицензирования хозяйственной деятельности по комбинированному производству тепловой и электрической 
энергии осуществляет национальная комиссия по государственному регулированию в сфере энергетики; предоставления разрешений на установку или сооружение когенерационных установок на базе существующих энергетических объектов; установления тарифов на электрическую и тепловую энергию, производимые когенерационными установками [8, с. 3].

Деятельность по энергосбережению в высших учебных заведениях предусматривает проведение санации зданий учреждений, которые полностью содержатся за счет средств государственного бюджета. Санация это комплекс технических мероприятий по восстановлению и повышению теплотехнических характеристик зданий до уровня, установленного современными требованиями, нормами, стандартами, уменьшение потерь энергоресурсов и воды, улучшение условий пребывания работников. В рамках санации выполняются: термоизоляция внешних стен здания, подвала и фундамента; модернизация кровли с возможным установлением на ней солнечных коллекторов модернизация тепловых, водопроводных, канализационных, вентиляционных и электрических сетей здания, перевод ее на электротеплоаккумуляционной обогрев; замена радиаторов отопления, установка приборов учета энергоресурсов и воды, внедрение многотарифного учета электроэнергии; строительство или модернизация котельной в здании; обустройство или ремонт тепловых пунктов; установления стеклопакетов, балконных блоков и входных дверей [9].

Наибольшее распространение в зарубежной практике при организации деятельности по энергосбережению получила технология энергосервиса, для которого контрольный подмеханизм будет иметь следующие содержание и структуру:

Блок 1. «Привлечение энергосервисных компаний». Госэнергоэффективности способствует внедрению технологии энергосервиса в бюджетной сфере, разработав типовую форму для отображения основной информации об энергопотреблении в зданиях бюджетных учреждений. Облгосадминистрации осуществляют ее заполнение и размещение на официальных сайтах для информирования потенциальных исполнителей энергосервиса о наличии возможностей внедрения энергоэффективных мероприятий на объектах бюджетной сферы. По этим данным энергосервисные компании выбирают наиболее привлекательные объекты в бюджетной сфере для применения энергосервиса.

Для осуществления энергосервиса подаются объявления на украинском и английском языках для размещения на сайте Госэнергоэффективности для привлечения энергосервисных компаний к процедуре открытых торгов или переговорной процедуры закупки услуг энергосервиса. В объявлении о закупке энергосервиса по процедуре открытых торгов указывают минимальный шаг повышения показателя эффективности энергосервисного договора в процессе электронного аукциона в процентах и математическую формулу, для учета показателей других критериев оценки, если такие существуют.

Тендерная документация включает: 1) инструкцию по подготовке тендерных предложений; 2) квалификационные критерии к участникам; 3) 
базовый годовой уровень потребления топливно-энергетических ресурсов и жилищно-коммунальных услуг в натуральной и денежной форме по ценам (тарифам), действующими на дату размещения объявления о проведении процедуры закупки. Он утверждается исполнительным органом местного совета или центральным органом исполнительной власти, в управлении которого находится заказчик энергосервиса путем принятия отдельных решений; 4) информацию по объектам энергосервиса и об оборудованию для поставки и потребления топливно-энергетических ресурсов, на основе которой готовятся тендерные предложения [10]; 5) перечень критериев и методика оценки тендерных предложений по учету других критериев, кроме показателя эффективности энергосервисного договора; 6) срок действия тендерных предложений (не менее 90 рабочих дней с даты раскрытия в электронной системе); 7) язык тендерных предложений; 8) предельный срок для подачи тендерных предложений; 9) информация контактного лица заказчика для общения с участниками процедуры закупки; 10) формулу расчета показателя эффективности энергосервисного договора; 11) требования относительно указания срока энергосервисного договора, величины ежегодных платежей исполнителю, годовой объем сокращения расходов заказчика енергсервиса, объем экономии ТЭР в натуральноми и относительном измерении по годам действия договора, фиксированный процент уменьшения расходов заказчика, который будет выплачиваться от экономии исполнителю, цену энергосервисного договора.

Для закупки энергосервиса по процедуре открытых торгов срок подачи тендерных предложений не может быть менее 30 дней с даты опубликования. Тендерная документация проектного предложения размещается на сайте Госэнергоэффективности. По результатам раскрытия тендерных предложений формируется список участников в порядке возрастания предложенной ими цены (приведенной цены). Протокол раскрытия тендерных предложений формируется и публикуется электронной системой закупок автоматически в день раскрытия предложений. Оценка тендерных предложений осуществляется в автоматическом режиме электронной системой закупок по критериям и методике, определенным заказчиком в тендерной документации, и путем применения электронного аукциона [4].

Бесплатно на сайте в течении дня от принятия решения о намерении заключить договор размещается сообщение о намерении заключить договор. Если объекты энергосервиса находятся в управлении различных распорядителей бюджетных средств, то назначается для процедуры закупки уполномоченное лицо. Уполномоченный заказчик и распорядители бюджетных средств отдельно заключают энергосервисные договора с победителем процедуры закупки относительно объектов, которые находятся в их распоряжении.

При условии применения переговорной процедуры тендерные предложения оцениваются по показателям эффективности энергосервисного договора, что является суммой продисконтированных разниц ежегодного со- 
кращения расходов заказчика и ежегодных платежей исполнителю энергосервиса в течении двадцатилетнего периода от объявления о проведении процедуры закупки услуг энергосервиса, и приведенным показателем эффективности энергосервисного договора, который указывают участники в тендерной предложения учитывая значение других критериев оценки по математической формуле, предусмотренной методикой, указанной заказчиком в тендерной документации.

Предложения размещаются по мере снижения показателя эффективности, в течении одного этапа электронного аукциона участник может повысить значение показателя эффективности энергосервисного договора или приведенного показателя эффективности энергосервисного договора один раз в предложении не менее чем на один шаг от предварительно указанного уровня показателя внося изменения в электронную систему закупок, что заключается в сокращении срока энергосервисного договора, уменьшении ежегодных платежей исполнителю энергосервиса. Заказчик и участник-победитель заключают энергосервисный в течение срока действия его предложения, до 60 рабочих дней от принятия решения о намерении заключить договор.

Блок 2. «Государственная регистрация энергосервисных договоров». Госэнергоэффективность осуществляет ведение и обновление списков эско-компаний, которые могут привлекаться к участию в публичных закупках услуг енргосервиса, обобщает информацию о первых заключенных в Украине договорах энергосервиса, обеспечивает ведение и обнародование Перечня предприятий, осуществляющих услуги по энергетическому аудиту, энергосервису, внедряют системы энергоменеджмента, ведет информационную базу потенциальных объектов энергосервиса (сведения вносятся на основании предоставления заполненной формы, разработанной Госэнергоэффективностью).

Блок 3. «Аккредитация исполнителей энергосервиса». Заказчик энергосервиса до десяти дней от принятия решения относительно намерений заключения договора на закупку энергосервиса с участником-победителем представляет на утверждение Госэнергоэффективности или соответствующему местному совету (относительно объектов в его распоряжении) существенные условия энергосервисного договора, которые утверждают или отказывают в утверждении в срок, не превышающий 60 рабочих дней с даты обращения главного заказчика энергосервиса для их утверждения.

Блок 4. «Мониторинг исполнения договоров энергосервиса». Мониторинг предусматривает оценку соблюдения исполнителем существенных условий договора энергосервиса в процессе его реализации, а именно: 1) осуществление в полном объеме мероприятий по перечню в установленные сроки при внедрении энергосервиса; 2) достижение совокупными расходами на оплату услуг энергосервиса цены энергосервисного договора прекращает его действие; 3) достижение планового уровня снижения затрат на оплату или объемов потребления ТЭР в натуральном выражении от осуществления энергосервиса в разрезе лет действия энергосервисного договора; 4) фиксированного процента сокращения расходов на оплату 
стоимости потребляемых топливно-энергетических ресурсов или жилищно-коммунальных услуг, который подлежит выплате исполнителю энергосервиса; 5) срок действия договора энергосервиса; 6) обеспечение соблюдения согласованных сторонами или определенные законодательством режимов и условий использования ТЭР (воздушно-тепловой режим, искусственное освещение, другие характеристики, соответствующие требованиям в области организации труда, содержания зданий, строений, сооружений) и др.

Блок 5. «Контроль исполнения энергосервисного контракта» предусматривает контроль соблюдения порядка оплаты энергосервиса за счет сокращения потребления и расходов на оплату энергоресурсов или услуг ЖКХ относительно уровня потребления без применения энергосервиса; условий и порядка расторжения энергосервисного договора, своевременности и полноты возмещения убытков, компенсаций или иных платежей за энергосервисным договором; порядка предоставления заказчику имущества, имущественных прав и ценностей, созданных за энергосервисным договором; порядка корректировки расчета результатов осуществления энергосервиса при изменениях в процессе реализации климатических условий, температуры наружного воздуха, назначения объекта энергосервиса, в конструкции или площади, порядка или режима работы объекта энергосервиса и тому подобное; порядка и методов измерения (расчета) и проверки фактического уровня сокращения потребления или расходов заказчика на оплату топливно-энергетических ресурсов и жилищно-коммунальных услуг в результате осуществления энергосервиса по сравнению с потреблением и затратами, которые были бы осуществлены при отсутствии энергосервиса. Важную роль играет контроль выполнения обязательств по энергосервисныму договору сторонами.

Фиксированный процент, по которому определяют сумму платы исполнителю энергосервиса, не может быть ниже 80 процентов суммы сокращения расходов заказчика энергосервиса на оплату соответствующих энергетических ресурсов или жилищно-коммунальных услуг. При условии частичного финансирования мероприятий по энергосбережению на объекте за бюджетные средства, заказчику разрешается определять максимальный размер фиксированного процента меньше 80\%. Срок действия энергосервисного договора должен быть не более 15 лет.

При недостижении планового уровня экономии потребления ТЭР или расходов на оплату жилищно-коммунальных услуг из-за неэффективности энергосервиса, при нарушении условий энергосервисного договора исполнителем энергосервиса, последний должен ликвидировать нарушения, в том числе путем применения дополнительных мер энергосервиса или оплатить заказчику сумму разницы между фактическим уровнем сокращения стоимости потребления ТЭР или расходов на оплату жилищно-коммунальных услуг и уровнем сокращения, вычисленным по условиям энергосервисного контракта.

Выводы и направления дальнейших исследований. Предложено рассматривать контрольный подмеханизм как совокупность функций контроля и 
мониторинга деятельности субъектов управления энергосбережением разных уровней, который реализуется через формирование информационной базы данных об эффективности действия МУЕСВУЗ и реализацию политики энергосбережения.

Согласно результатам исследования контрольного подмеханизма МУЕСВУЗ, который реализуется Госэнергоэффективностью, выделены пять блоков: 1) привлечение к деятельности по энергосбережению; 2) государственная регистрация; 3) аккредитация и реализация деятельности по энергосбережению; 4) мониторинг в сфере энергосбережения; 5) контроль в сфере энергосбережения - в разрезе которых распределены задачи и функции энергосбережения.

Анализ реализации концепции перфоманс-контрактинг в украинских реалиях позволил определить особенности организации контроля при использовании энергосервисных договоров, что разрешило выделить пять основных блоков. Изучение взаимодействия субъектов и объектов энергосбережения в пределах энергосервиса проявило роль отдельных субъектов энергосбережения, особенности принятия, согласования, регламентирования и реализации управленческих решений. Выделение блоков контрольного подмеханизма в реализации технологии энергосервиса подтвердило соответствие проведенной структуризации контрольному подмеханизму, который реализуется Госэнергоэффективностью в процессе выполнения основных задач и функций, что делает возможным совершенствование и систематизацию законодательно-нормативного обеспечения энергосбережения.

Указанный подход следует распространить на все технологии и инструменты функционального подмеханизма МУЕСВУЗ.

References:

[1] 0 внутреннем и внешнем положении Украины в 2015 году: Аналитический доклад к Ежегодного Послания Президента Украины в Верховную Раду Украины [Текст]. - М .: НИСИ, 2015 - 684 с.

[2] О Национальной комиссии, осуществляющей государственное регулирование в сфере энергетики и коммунальных услуг: Закон Украины // Ведомости Верховной Рады (ВВР). - 2016. - №51. - 83 с. - Режим доступа: http://zakon5.rada.gov.ua/laws/show/1540-19.

[3] Задачи и функции [Электронный ресурс] / Госэнергонадзор. - Режим доступа: https://den.energy.gov.ua/home/zavdannya-ta-funktsiji.

[4] О публичных закупках: Закон от 25.12.2015 № 922-VIII [Электронный ресурс] // Ведомости Верховной Рады (ВВР). - 2016. - № 9. - 3 с. - Режим доступа: http://zakon3.rada.gov.ua/laws/show/922-19.

[5] Положение о Государственном агентстве по энергоэффективности и энергосбережению Украины [Электронный ресурс]: Утверждено постановлением Кабинета Министров Украины от 26 ноября 2014 № 676. - Режим доступа: http://saee.gov.ua/uk/about/polozhennya- derzhenerhoefektyvnosti-ukrainy.

[6] 0 программах повышения энергоэффективности и уменьшения потребления энергоресурсов: Распоряжение Кабинета Министров Украины от 17 декабря 
2008 № 1567-p. [Электронный ресурс] / КМУ. - М. - Режим доступа: http://zakon2.rada.gov.ua/laws/show/1567-2008-\%D1\%80.

[7] Об энергосбережении: Закон Украины от 1 июля 1994 № 74/94-ВР (с изм. И доп.) [Электронный ресурс] // Ведомости Верховной Рады Украины (ВВР). - 1994. - № 30. - 102 с. - Режим доступа: URL: http://zakon4.rada.gov.ua/laws/show/74/94\%D0\%B2\%D1\%80.

[8] О комбинированном производстве тепловой и электрической энергии (когенерации) и использовании сбросного энергопотенциала: Закон Украины от 5 апреля 2005 г. № 2509-IV [Электронный ресурс] // Ведомости Верховной Рады Украины (ВВР). - 2005. - № 20. - Режим доступа: http://saee.gov.ua/documents/laws/Zakon-4.doc.

[9] 0 продлении срока выполнения Государственной целевой экономической программы энергоэффективности и развития сферы производства энергоносителей из возобновляемых источников энергии и альтернативных видов топлива на 2010-2015 годы: Постановление Кабинета Министров Украины от 11.11.2015 № 929 [Электронный ресурс] / Кабинет министров Украины. - М., 2015, ноябрь. - 3 c. - Режим доступа: http://saee.gov.ua/sites/default/files/KMU_929.zip.

[10]0 введении новых инвестиционных возможностей, обеспечение прав и законных интересов субъектов предпринимательской деятельности для проведения масштабной энергомодернизации: Закон Украины от 9 апреля 2015 № 327-VIII [Электронный ресурс] // Ведомости Верховной Рады (ВВР). - 2015. - № 26. - Режим доступа: http://zakon3.rada.gov.ua/laws/show/327-19. 


\section{POSSIBILITIES OF INCREASING ECONOMIC POTENTIAL OF INDUSTRIAL ENTERPRISES OF UZBEKISTAN (ON THE EXAMPLE OF JSC «UZBEKLIGHTINDUSTRY»)}

\section{B. Usmanov ${ }^{1}$}

\section{Abstract}

The article reveals the role and importance of Uzbekistan's light industry in the country's socio-economic development, as well as its current development trend. Also, the author's definition of the theoretical basis of the economic potential of enterprises, in particular, the notions of «potential», «economic potential» and «economic potential of enterprises» is analyzed and given.

Taking into account the specifics of the development and activities of light industry in Uzbekistan, an author's definition of the economic potential of a light industry enterprise is given.

Keywords: light industry; potential; economic potential; economic potential of enterprises; resources; stock; ability.

In the context of Uzbekistan's intensive integration into the world economy, the ongoing global economic crisis and the changing world market situation, the creation of an optimal management system for light industry enterprises effectively using its potential, in particular production, financial and technological opportunities is topical. Adoption and development of management decisions that provide for the provision of effective activities should be based on objective and reliable information on the potential of enterprises. Moreover, planning and developing business effectively using the potential of light industry enterprises is the main factor in the sustainable development of these enterprises. In fact, in making all managerial decisions, economic potential is taken into account, but issues related to the assessment of the use of economic potential are still relevant.

To date, the demonstration of light industry enterprises of their potential is considered important when exiting the crisis without losses, receiving income. In this process, the assessment of the level of use of the economic potential of the enterprise and the establishment of priority directions based on information on the actual use of financial and production resources are of particular importance.

Light industry of Uzbekistan plays an important role in the socio-economic development of the country. Since, light industry is the basis for ensuring sustainable economic growth, increasing revenues from exports, sustainable development of small businesses and private entrepreneurship, as well as providing employment for the population, raising incomes and welfare of the population.

Today light industry is an industry not only developing at a high pace, but is also considered to be a sector that steadily increases its exports, attracts foreign

${ }^{1}$ Bunyod Usmanov, student, Tashkent State University of Economics, Uzbekistan. 
investments and fundamentally modernizes and technically and technologically renews production processes.

In recent years, the volume of production in the light industry has been growing at a high rate and the share of production in the gross domestic product has been substantially increased. Including, if in 2010 the share of light industry in GDP was 7.4\%, then in 2016 this indicator increased by $2 \%$ and amounted to $9.4 \%$. Also, the growth rate of the industry in 2016 compared to 2015 was $124.5 \%$ and the share of the industry in industrial production was $15.0 \%$. The share of light industry enterprises in the country's exports is also growing, including if in 2010 the share of light industry in the country's exports was 4.8\%, in 2016 this figure was $12.7 \%$ [19].

To the sustainable development of the industry led reforms carried out on modernization, technical and technological renovation and diversification of production.

According to the above analysis, we can say that the light industry is developing at a high rate. But in general, Uzbekistan does not fully use the available potential and reserves of light industry. And this once again shows the urgency of carrying out scientific and practical research into the study of the reserves and economic potential of light industry enterprises.

As is known, to date, a number of studies have been carried out to study the economic potential of industrial enterprises, its structure, and valuation indicators. But there are no studies on the development of scientifically and practically proven proposals for the creation of a mechanism that fully embraces the features of the development of industries in the real sectors of the economy and increases the economic potential of light industry enterprises and its evaluation indicators.

Based on the foregoing, in our opinion, it is advisable to scientifically formulate and uncover the economic essence of the concept of «economic potential», its structure and evaluation indicators for light industry enterprises taking into account the organizational and economic significance, composition and features of light industry development.

For this, first of all, it is necessary to analyze scientific approaches on the concepts of «potential», «economic potential».

The concept of «potential» comes from the Latin word «potential» and means strength, secret possibilities. According to this concept in economic theory, V.M.Arkhipov [1, pp.75-89] gives the following definition: «potential» - is the attracted funds, reserves and sources for the solution of certain goals and tasks.

At the enterprise level, the concept of «potential» is given by G.B.Kleiner, V.L.Tambovsev and R.M.Kachalov [2, p.288] as an interesting definition, that is, by their definition, the potential of a certain enterprise is the component parts that characterize resources, state and movement in the external socio-economic environment.

Also, it is necessary to emphasize the definition of the concept of «potential», given by N.K.Temnova [3, p.14], that is, «potential» is not only resources, but also purposeful activity and the possibility of obtaining a result. The author asserts that the potential» needs to use a synergetic approach. 
B. Rayan [4, p.615] gives a general definition at the level of the organization, that is, «the organization's capacity is the real and probabilistic ability to perform a purposeful task».

Also, from the point of view of the financial and economic activity of the enterprise, I.N. Bogataya gave a definition of the concept of «enterprise potential» in accounting. In her opinion [5, p.320], «the potential of the enterprise is the assets, the sources of their formations and their ability, leading to certain financial results at the end of the financial and economic activities».

In many cases, the concepts of «potential», «stock» are understood in the same way. Including, economists S.B.Barngolts [6, p.214] and G.V.Savitskaya [7, p.288] give the following definition: «the enterprise's potential is constantly produced material resources to meet additional needs under certain conditions, on the other hand, these are not used opportunities to improve production efficiency».

Taking into account the above definitions, it can be said that the «potential» is the means, capabilities, ability, in particular, of a set of unused stocks in the activities of economic entities, viewed as the real covered capacities of the enterprise with changing certain conditions.

Believing about what means, stocks and sources there is a speech in definition of concept «potential», there is an opportunity of its application in different branches of science and economic activity. The definition of the concept of «potential» in this way makes it possible to widely apply it in different directions of economic activity of organizations and enterprises and it can be called «economic potential».

As a result of studying and analyzing the concept of «economic potential» as an economic category, it can be said that it has not only a theoretical value, but also practical properties. Now let us examine in detail the meaning and composition of the «economic potential».

According to the scientist economist MI Bukhalkov [8, p.392], «the economic potential of any enterprise reflects the composition of resources: labor, material, financial and other resources, for the production of planned works and services».

In V.S.Spirin's [9] opinion «the economic potential is determined by the totality of resources that unite existing and unused reserves».

In the opinion of B.A.Raizberg's [10, p.384] «economic potential determines the effective use of all sorts of limited resources of the enterprise to maximize profits and is the main component of the production potential and economic system».

L.S.Sosnenko [11, p.208] proposes to divide the study of «economic potential» as an object in two directions. On the one hand, economic potential is considered as the general resources of economic entities, and on the other hand, the ability of economic agents to attract and use resources to meet the needs of society.

In the work of the team of authors [12, p.672] the following definition is given: «economic potential - sources, capabilities, means and reserves used by the organization to achieve goals and solve certain tasks in the relevant industry». 
Uzbek economists have proposed the following definition of «economic potential», that is, «the economic potential of an enterprise is the aggregate of material, labor and intangible assets for the full provision of a perfect economic process» [13, p.138].

Taking into account the above definitions of economic potential, they can be divided into two areas:

- economic potential is a set of certain resources;

- economic potential is the ability to achieve concrete results of productive forces.

In the first direction, the concept of «economic potential» is an approach only in terms of resources. This does not allow full disclosure of the economic significance of economic potential. In the second direction, the results of using the economic potential are considered.

In the theory and practice of each business entity, targeting is necessary, but it can not be accomplished without economic growth and development, increasing efficiency and competitiveness, and the capabilities of stocks that are sources and means for achieving the goals.

From this point of view, in our opinion, the third approach, harmonizing with the above two directions, can be cited to the concept of the economic potential of light industry enterprises. This approach should take into account the ability to use resources at the maximum level and achieve efficiency of light industry enterprises.

In some scientific economic studies, there are close approaches to such an approach to the economic potential of enterprises. In particular, professor V.V.Kovalev [14, p.560] understood the economic potential of the enterprise as an enterprise's ability to achieve its goals, using material, labor and financial resources.

R.V.Marushkov in his scientific work [15, p.20] defines economic potential as the enterprise's ability to perform long-term activities and achieve strategic goals using a system of current resources.

In the opinion of E.V.Zhoglina [16, p.26] «economic potential is a common ability that reflects in itself specific systems of conducting economic and production activity (production of products, services, meeting the needs of the population, ensuring production and development of consumption) on the basis of natural, material, financial, labor and intellectual resources».

Reduced O.A.Zhigunova's [17, p.140] approach to the economic potential of the enterprise is particular importance. In it, when determining the economic potential of an enterprise, the sustainable activity of the enterprise, the ability to withstand unfavorable situations, as well as the objectives of enterprise development, comes to the forefront, and the following definition is made: «the economic potential of an enterprise is the general ability and properties of obtaining opportunities with the condition of relations between the external and internal environment, ensuring sustainable development and achieving strategic goals, carefully using resources».

From the point of view of the economic potential of commercial enterprises, the following approach is presented: «economic potential is the ability to achieve 
the goals set for the enterprise based on the effective use of resources in terms of relationships between external and internal factors» [18, p.25].

Summarizing the foregoing, taking into account the definitions of the concepts «potential», «economic potential», «economic potential of enterprises» and specifics of the development and activities of light industry, the following definition can be made of the economic potential of light industry enterprises. The economic potential of light industry enterprises is the ability to ensure longterm sustainable development, efficiently and carefully using resources, as well as shaping, identifying and meeting the demand for light industry products on the market in the process of interaction with the external environment.

\section{References}

[1] Arkhipov V.M. Designing the production potential of associations (theoretical aspects) - L.: Publishing of Leningrad State University, 2009. -pp.75-89.

[2] Kleiner G.B., Tambovsev V.L., Kachalov R.M. Enterprises in an unstable economic environment: risks, strategies, security. - M: Economics, 1997. - 288 p.

[3] Temnova N.K. Economic dynamics of textile enterprises: theoretical, methodological and applied aspects: the author's abstract. Dis .. doc. econ. sciences. / Temnova N.K. Ivanovo, 2009. -14 p.

[4] Rayan B. Strategic accounting for the manager. / Transl. from english. Ed. Mikryukova V.A. - M.: Audit, UNITI, 1998. - 615 p.

[5] Bogataya I.N. Strategic accounting of the property of the enterprise. - Rostov n/D.: "Fenix", 2001. -320 p.

[6] Barngolts S.B. Economic analysis of economic activity at the present stage of development. - M.: Finance and Statistics, 1984. - 214 p.

[7] Savitskaya G.V. Theory of analysis of economic activity: Textbook. - M.: INFRA-M, 2005. - $288 \mathrm{p}$.

[8] Bukhalkov M.I. Intrafirm planning. - M.: INFRA-M, 2000. -392 p.

[9] Spirin V.S. The main features of modern structural changes in the production capacity of the enterprise // Consultant Director. - 2004. - №15.

[10] Raizberg B.A. State management of economic and social processes. - M.: INFRA-M, 2008. - $384 \mathrm{p}$.

[11] Sosnenko L.S. Analysis of the economic potential of the operating enterprise. - M.: Economic Literature, 2004. - $208 \mathrm{p}$.

[12] Alekseyeva A.I., Vasilyev Yu.V., Maleeva A.V., Ushvitsky L.I. Comprehensive economic analysis of economic activity: Textbook - M.: Finance and Statistics, 2006. - 672 p.

[13] Pardaev M.K., Khasanov B.A., Isroilov Zh.I., Kholikulov A.N. Economic analysis. Textbook. T.: TSUE and SamIES, 2011. - 138 p.

[14] Kovalev V.V. Financial analysis: methods and procedures. - M.: Finance and Statistics, 2001. - $560 \mathrm{p}$.

[15] Marushkov R.V. Estimation of the use of the economic potential of the enterprise (by the example of the enterprises of the printing industry), author's abstract of. dis ... cand. econ. sciences: 08.00.05 / Marushkov R.V. - M.: 2000. -20 p.

[16] Zhoglina E.V. Harmonization of mechanisms for managing the development of economic potential: author's abstract. dis ... cand. econ. sciences: 08.00.05 / Zhoglina E.V. - Stavropol, 2008. - 26 p.

[17] Zhigunova O.A. Theory and methodology of analysis and forecasting of the economic potential of the enterprise: Monograph. - M.: Publishing house "Finance and Credit", 2010. - $140 \mathrm{p}$. 
[18] Shepetova V.N. The system-target approach to the analysis of the economic potential of a commercial organization: author's abstract. dis ... cand. econ. sciences: 08.00 .05 / Shepetova V.N. - Orel, 2008. - 25 p.

[19] Data of the official website of JSC "Uzbeklightindustry". 


\title{
APPROXIMATION TO EUROPEAN UNION ENVIRONMENTAL LEGISLATION: EVOLUTIONARY AND REVOLUTIONARY APPROACHES FOR UKRAINE
}

\section{A. Kraskovska ${ }^{1}$}

\begin{abstract}
The Association Agreement between Ukraine and the European Union, signed in 2014, provides so-called evolutionary approach for the process of approximation of legislation, the essence of which is to gradually bring Ukrainian legislation in line with the content and objectives enshrined in the EU law, at the same time stressing the importance of revolutionary approach and envisages "transposition" of EU law norms to the law and order of Ukraine in spheres where regulation of relations is not covered by the provisions of national legislation. This article examines the means and conditions in which Ukraine should develop its own approaches to addressing the issue of harmonizing legislation with EU law, including cases of transposition of EU directives into the domestic legislation of Ukraine and the direct application of certain provisions of EU law at the national level.
\end{abstract}

Keywords: approximation, environment, evolutionary approach, transposition, European Union, Ukraine.

European Union brings to the countries applying for accession to it, a large list of quality requirements in different spheres, aiming to achieve a certain level of financial security policies to protect the environment [9]. Countries aspiring to join the European Union must align their national laws, rules and procedures in order to give effect to the entire body of EU law contained in the acquis communautaire. The approximation process is typically seen as consisting of three elements: adoption or transposition, implementation, and enforcement (Figure 1).

Despite broad European legal studies, until now neither the international legal theory nor modern law-making practice has paid enough attention to the theory of harmonization of legislation of third countries with the European law, clarification of basic concepts and approaches of this phenomenon, although harmonization is one of the most relevant and in foreign legal theory, especially in the modern EU law.

\footnotetext{
${ }^{1}$ Anastasiia Kraskovska, PhD candidate of Department of Political Sciences "Jean Monnet", University of Campania Luigi Vanvitelli, Caserta, Italy.
} 


\begin{tabular}{|c|c|c|}
\hline Adoption / Transposition & Implementation & Enforcement \\
\hline $\begin{array}{l}\text { - Competent national authorities } \\
\text { take legislative, regulatory and } \\
\text { administrative measures in order } \\
\text { to incorporate the EU's } \\
\text { environmental directives into } \\
\text { national law: compare existing } \\
\text { national legislation with the } \\
\text { measures that the environmental } \\
\text { acquis requires to adopt in order } \\
\text { to identify gaps that need to be } \\
\text { addressed during the } \\
\text { approximation process; determine } \\
\text { the scope of discretion that they } \\
\text { have when transposing EU laws } \\
\text { into their national legislation; } \\
\text { after that actual transposition of } \\
\text { the requirements must occur (by } \\
\text { either adopting new legislation or } \\
\text { modifying existing legislation to } \\
\text { achieve the requirements of the } \\
\text { EU acquis). } \\
\text { - National environmental } \\
\text { legislation and government's } \\
\text { administrative capabilities should } \\
\text { be also taken into account. It may } \\
\text { be necessary to create new } \\
\text { administrative structures or } \\
\text { modify and enhance the } \\
\text { environmental standards within } \\
\text { the country, in order to }\end{array}$ & $\begin{array}{l}\text { - Implementation actions include the } \\
\text { creation of reliable data collection } \\
\text { systems, effective systems of } \\
\text { monitoring and reporting, increasing } \\
\text { the awareness of industry and the } \\
\text { public in environmental matters, and } \\
\text { facilitation of public participation in } \\
\text { environmental issues. Development } \\
\text { of competent national authorities to } \\
\text { carry out environmental } \\
\text { administration is the most important } \\
\text { part of this stage. } \\
\text { - Compliance is left to the discretion } \\
\text { of applicant countries,and is often } \\
\text { done at the local or regional level of } \\
\text { government. Significant } \\
\text { improvement in administration is } \\
\text { required in most countries. } \\
\text {-Due to financial constraints and the } \\
\text { amount of improvement that is } \\
\text { necessary, applicant countries have } \\
\text { requested transition periods from } \\
\text { the EU in order to comply with the } \\
\text { environmental acquis. } \\
\text { - Transition periods may be granted } \\
\text { only for some elements of the } \\
\text { acquis which require significant } \\
\text { investments. }\end{array}$ & $\begin{array}{l}\text { - The environmental acquis contains } \\
\text { the environmental standards that EU } \\
\text { members must satisfy. Enforcement } \\
\text { of these standards is then left to the } \\
\text { member states and often based on } \\
\text { self-monitoring. } \\
\text { - Self-monitoring allows individuals } \\
\text { within the country to monitor } \\
\text { compliance with environmental } \\
\text { regulations. The EU views self- } \\
\text { monitoring as the ideal mechanism } \\
\text { for enforcement, because it passes the } \\
\text { costs of monitoring to the individual } \\
\text { and it satisfies the polluter pays } \\
\text { principle. } \\
\text {-Inspections should still be conducted } \\
\text { as part of the enforcement process on } \\
\text { the basis of information supplied } \\
\text { through self-monitoring to ensure that } \\
\text { environmental requirements are being } \\
\text { complied with. } \\
\text { - While additional administrative } \\
\text { personnel are necessary to adequately } \\
\text { enforce environmental requirements, } \\
\text { most applicant countries are seen as } \\
\text { having "reasonable inspection } \\
\text { procedures." } \\
\text { - Enforcement also requires that } \\
\text { appropriate penalties be established } \\
\text { for violations of environmental } \\
\text { legislation. Violations are punished } \\
\text { by fines in most countries. }\end{array}$ \\
\hline
\end{tabular}

successfully transpose the acquis

\section{Figure 1. Elements of approximation process to the EU environmental acquis}

With the launch of Eastern Partnership (EP) in 2009, the EU stepped up its involvement in Eastern Europe and the South Caucasus. Through the EP, it offers upgraded contractual relations, deeper economic integration, progressive visa liberalisation and enhanced sectoral cooperation. In case of Ukraine and its Association Agreement with the EU, there are five major problems hindering legal approximation in the field of environmental law: the complexity of the acquis communitaire to be adopted; institutional coordination; implementation capacities; costs of approximation and political sensitivity in partner countries [3].

The choice of measures may also be governed by the form or type of EU legislation [2]. EU regulations can be applied directly and may not be transposed into national law (in case of Ukraine it is supposed to happen in both ways). The responsibility of approximation and implementation of EU laws is usually carried out by at least one authority at national level, performing the functions of the European Union's interlocutor [4]. Main steps for the approximation of the environmental legislation in Ukraine to the EU Directives are suggested in Figure 2. 
Step 1. Type of law and its requirements

Type of law: directive, regulation, decision, its aims and objectives, competent authorities, the scope of information collected and provided to the European Commission, required planning, scientific or technical knowledge, consultation procedures and investments

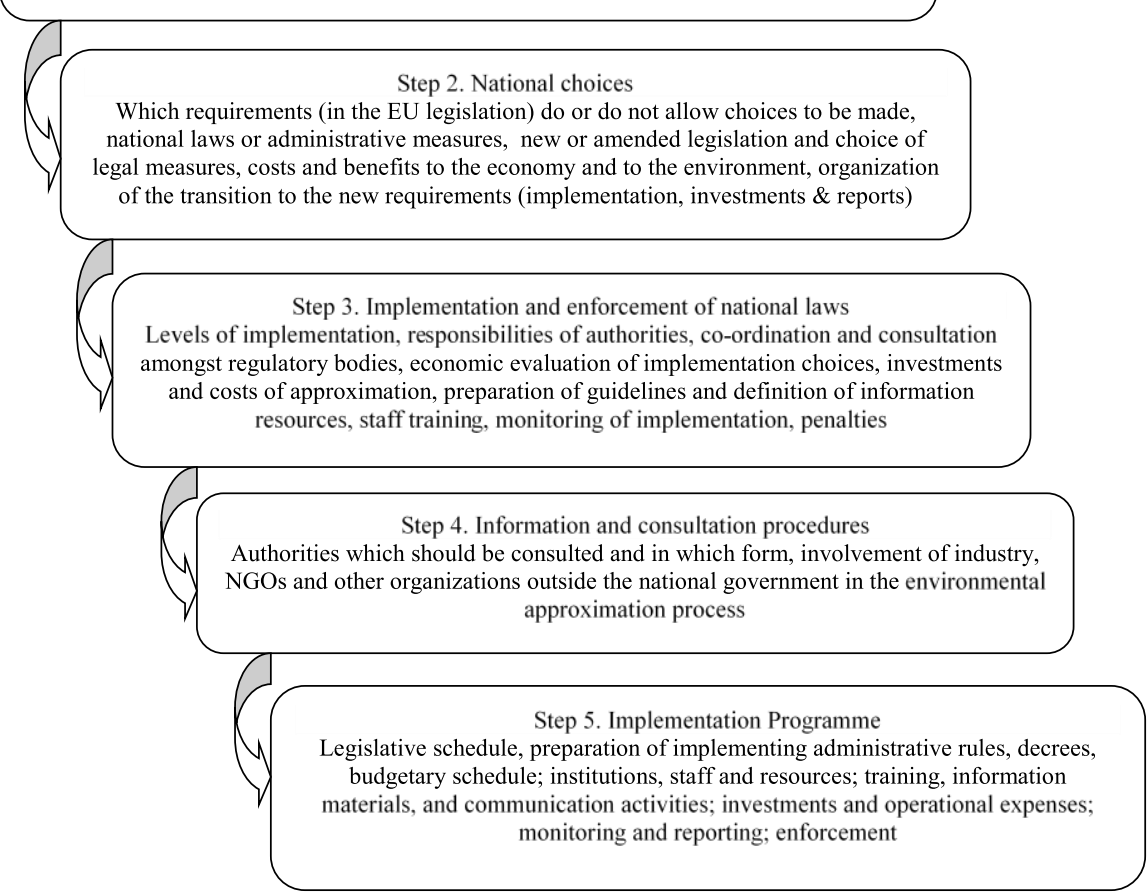

Figure 2. Steps to the Approximation of national legislation to EU Directives

Ukrainian international obligations after signing Partnership and Cooperation Agreement with the European Communities and their Member States in 1994 (PCA), Association Agreement between the European Union and Ukraine in 2014 (Association Agreement), as well as the adoption of other documents, which defined the legal framework for cooperation of the EU organization with Ukraine, created the appropriate prerequisites for the harmonization of national legislation with the EU norms by using both evolutionary and revolutionary approaches.

At this point Ukraine should develop its own approaches to addressing the issue of harmonizing legislation with EU law, because the implementation of this mechanism provides opportunities for the EU law to be applied within the framework of domestic law and order. This concerns both cases of transposition of EU directives into the domestic legislation of Ukraine (evolutional) and the direct application of certain provisions of EU law at the national level (revolutional approach).

Adjusting Ukrainian law to EU standards can be defined as a "voluntary harmonization" by which the harmonizing state "adapts its national law to EU law rules which have no binding force in relation to that state." Ukraine chose the 
legislative form of voluntary harmonization; that is, it reproduced EU law in its national legislation. In this case we can also use the term "legal transplantation", coined by Alan Watson in his book "Legal Transplants: An Approach to Comparative Law". According to the typology made by Jonathan M. Miller, we could classify the process of harmonization of Ukrainian environmental legislation as costsaving, externally dictated and entrepreneurial transplantation of European Union legislation.

Use of transposition principles and practices belong to the formal phase of approximation (harmonization, transposition, etc.) of European Union legislation into potential Member Country's legislation [1] In case of Ukraine as a third country, transposition principles are supposed to include 'no gold-plating' and 'copy out', as well as the 'timely transposition' and 'double-banking'. EU regulations also foresee the adoption of complementary national legislation, for the purpose of identification and establishment of responsible authorities, implementation of orders and decrees, and other detailed requirements. Transposition of EU environmental legislation in Ukraine may be seen as part of a multilayered process that embraces next 4 stages (phases) (Figure 3):

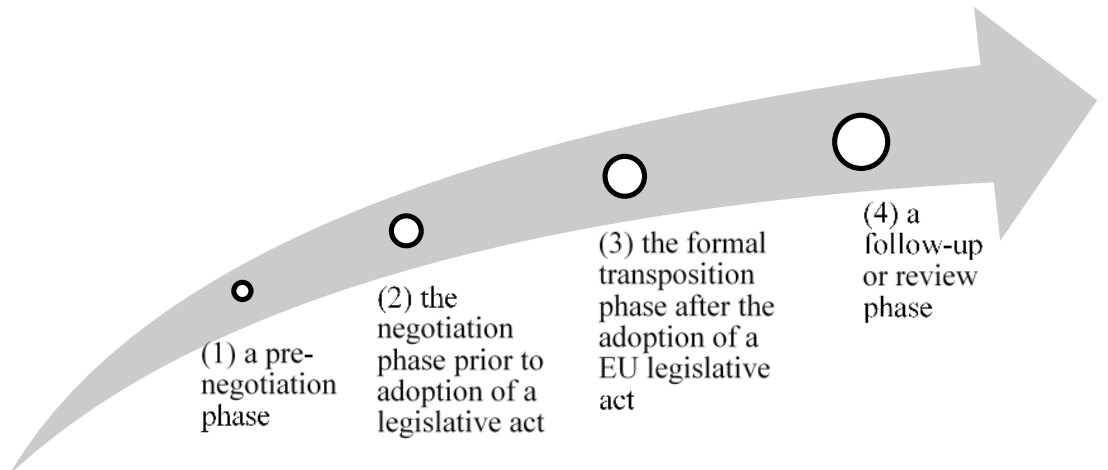

Figure 3. Stages for transposition of EU environmental legislation

Harmonization of Ukrainian legislation with EU law by joining to international standards can also be extended to sectors where cooperation is not provided according to the Association Agreement provisions. In fact, harmonization through the accession to international instruments that establishes legal standards in certain sectors is more likely to be an auxiliary way of ensuring approximate equivalence of the laws of Ukraine and the law of the European Union.

Implementation of the legal harmonization processes of the EU acquis into the law of third countries is supported and performed by applying material and procedural methods [5]. The "material ways" of transposing the "acquis communautaire" include: homogeneity, convergence of legislation, mutual recognition of standards and legislation. The "material methods" aim at the transposition of two types of "EU acquis" in the legal systems of third countries in the EU's external relations. 
"Procedural modalities" for the transposition of the acquis communautaire into the legal systems of third countries are going through: formal / informal participation in EU legislative procedures, information sharing, as well as technical and financial assistance from the EU. The specific objectives and tasks of the EU's external agreements are of great importance to the nature of the transposition in this case.

The impact of institutes created within the framework of EU external agreements on the transposition of the EU acquis into the legal systems of third countries is expressed in the formation of at least two, or three, joint institutions. They greatly contribute to the transposition of constitutional and institutional values and EU basic principles and serve as a means of convergence of political regimes and the rule of law in third countries with European "common values".

At the moment it can be argued that the Association Agreement between the EU and Ukraine has no analogues, takes a place different from the EU's external agreements and is the prototype of a separate group of EU external agreements on association with neighbouring countries [7].

Conclusions. To achieve successful cooperation, the EU Association Agreement contains so-called "conditional clauses" and provisions on convergence of national legislation and the EU acquis [8]. These reservations include Ukraine's access to the EU internal market, in case of successful development of political, economic and legal reforms. In addition, "conditional clauses" provide for regular monitoring of the implementation of reforms in Ukraine and the observance of democratic standards by the Ukrainian authorities.

In contrast to the Agreement on Partnership and Cooperation, Ukraine-EU Association Agreement does not contain any "soft law" measures, providing for clear obligations of the parties. Of particular importance is the creation, through organizational means, of a mechanism for managing the process of harmonization at the national level, which involves screening legislation, control, impact assessment, prioritization, etc. Its legal principles are defined in the National Program of Adaptation of Ukrainian Legislation to the Legislation of the EU [6].

The process of "integration without membership" takes place within the framework of sectoral multilateral cooperation and differentiated integration into the EU, which involves approximation of legislation through the voluntary application. Usually, sectoral multilateral cooperation takes place through the conclusion of sectoral bilateral agreements between the EU and third countries, such as the European Economic Area Agreement and bilateral agreements between the EU and Switzerland. The obvious positive impact of multilateral cooperation between Ukraine and the European Union testifies the fact that the formation of a European legal space is impossible without the successful Europeanization of third countries.

\section{References}

[1] Anker, H., de Graaf, K., Purdy, R. and Squintani, S. (2015). Coping with EU Environmental Legislation-Transposition Principles and Practices. Journal of Environmental Law, 2015, 27, 17-44 
[2] European Commission (2015). Guide to the Approximation of European Union Environmental Legislation.

[3] European Union Directorate General for External policies (2013) Approximation of the national legislation of Eastern Partnership countries with EU legislation in the economic field. May 2013, EUDEP, Policy Department

[4] Oleshko, 0. (2009) In search of Ukraine's identity: the geopolitical condundrum of a country lodged between East and West. The Prague Journal of Central European Affairs, Summer, 2009, Vol.12(3), p.30(3)

[5] Petrov, R. (2003) The notion of «acquis communautaire» in the law of the European Union. Law of Ukraine, 2003, № 9, pp. 142 - 146.

[6] Petrov, R. (2010) Adaptation of Ukrainian legislation to EU law in Association Agreements. Mediterranean experience. European studies and law, 2010, № 1

[7] Petrov, R. (2010) European Economic Area Agreement- integration model without formal membership in the EU. European studies and law, 2010, № 2.

[8] Petrov, R., Kalinichenko, A. (2011) The Europeanization of Third Country Judiciaries through the Application of the EU Acquis: The Cases of Russia and Ukraine. International and Comparative Law Quarterly (Cambridge University Press). 2011, № 60 (2), pp. $325-353$.

[9] Scott, J. (2009). Environmental protection: European law and governance (The collected courses of the Academy of European Law; v. 18/3). Oxford: Oxford University Press. 


\section{DEVELOPMENT OF INFRASTRUCTURE LOGISTIC ASPECTS}

\section{N. Ivanova ${ }^{1}$}

\section{Abstract}

The development of infrastructure takes into consideration the following premises. Firstly, regional infrastructure acts both as a specific public institution and a type of economic activity. Secondly, the vector of logistics transformations of infrastructure potential due to the peculiarities of the socio-economic relations and the process of reproduction, which are formed within a specific regional area. Thirdly, the process of modernization of production infrastructure is designed to optimize the relationship of material, financial and information links in the formation of the regional logistic flows.

Keywords: infrastructure, infrastructure capacity, logistics, environment, ecological safety, transport, warehouse.

Integration of national logistic system in the European and global logistic network should take place, taking into account not only the economic, technical, spatial, market and social conditions.

The largest share of the logistic activities in Ukraine has the transport industry. At the same time, transport has a significant environmental impact, is a source of thirds of harmful substances in Ukraine. The greatest concern it is about road transport in the cities where its share in the emissions of pollutants reaches $90 \%$.

However, it should be noted that in Ukraine there is a delay of roads and transport network development, especially the development of public roads on the rate of motorization of the country. Technical standards of roads in Ukraine do not meet EU standards for quality and for the weight filling, so there is a need to direct it to the EU requirements. $\mathrm{n}$ the implementation of environmental policies, among other principles, EU guides two main policies, which should be laid to the basis of the ecological methodology of logistic system in Ukraine [1

Nowadays in the Europe there is a spreading of the concept of «sustainable transport» (or "green transport»), which is used to describe any type of transport with a low environmental impact. In Ukraine there are signs of implementations of the principle of prevention in the field of environmental policy about sustainable transport. Thus, on 26 June 2015, Ukraine signed a protocol about sustainable transport to the Convention on the Protection and Sustainable Development of the Carpathians.

In cities, switching to cleaner transport is facilitated by the lower requirements for vehicle range and higher population density. Public transport choices are more widely available, as well as the option of walking and cycling. Cities

\footnotetext{
1 Nataliia Ivanova, Doctor of Economic Sciences, Professor, Chernigov National University of Technology, Ukraine.
} 
suffer most from congestion, poor air quality and noise exposure. Urban transport is responsible for about a quarter of $\mathrm{CO}_{2}$ emissions from transport, and $69 \%$ of road accidents occur in cities [2

The gradual phasing out of "conventionally fuelled" vehicles from the urban environment is a major contribution to significant reduction of oil dependence, greenhouse gas emissions and local air and noise pollution. It will have to be complemented by the development of appropriate fuelling/charging infrastructure for new vehicles [3

Modern logistic centers are characterized by a large amount of realized services, by a wide range of the operations and by a significant list and level of turnover of nomenclature positions. This intensity of the logistic activity is dictated by the transformation processes which are taking place in the market of logistic services under the influence of global trends in globalization and integration processes. A special distribution in this time is being received transport-distribution centers that allow consolidate geographically dispersed local logistic markets. The main object here is a control of multi-directional material and accompanying information and financial flows. Therefore, there is a need to increase the number of companies that automate logistic functions based warehouse management systems. Traditionally barcoding is using to perform this task. Modern innovative solution in this area is the use of RFID-technology (radio frequency identification), it refers to the automatic identification of objects of logistic flow via the radio signals.

Another area of spreading the use of IT technologies in logistic solutions is a comprehensive automated warehouse management systems (WMS), which not serve only for information support of the movement of inventory, but in realtime control the material, cash and information flows that pass through the warehouse. WMS allow to provide a control of inventory at all technological stages considering all the features and requirements for storage.

In developed countries the development and implementation of systems of automated control of warehouse complexes occupied by hundreds of specialized firms. There are plenty of different configurations systems that allow to adjust to the demands of the consumer. WMS integrate with barcoding equipment and radio terminals, and in addition combine with production management systems of MRP classes (Material Requirement Planning), ERP (Enterprise Resource Planning), CSM (Chain Supply Management) [4].

Experts recommend to introduce a system of class WMS in those companies for which the number of nomenclature positions more than 300 units and the storage area of over 2000 square meters, and the turnover rate of products in the storage less than 30 days [4].

The use of smaller, lighter and more specialised road passenger vehicles must be encouraged. Large fleets of urban buses, taxis and delivery vans are particularly suitable for the introduction of alternative propulsion systems and fuels. These could make a substantial contribution in reducing the carbon intensity of urban transport while providing a test bed for new technologies and opportunity 
for early market deployment. Road pricing and the removal of distortions in taxation can also assist in encouraging the use of public transport and the gradual introduction of alternative propulsion [5].

So, infrastructural development is always a contested process, tied as it is to questions around access, power, and the life chances of groups and individuals. Would-be developers of infrastructure work within pre-constituted fields, and regularly encounter actors, both entrenched and emergent, who will see in the development of infrastructure opportunities for both gain and loss - and gauge their responses accordingly. This aspect of infrastructure has obvious implications for equity, participation, and a range of other broad social goals (including those expressed in NSF's Cyberinfrastructure Vision for the 21st Century). It is also an issue of strategic management, fit, and long-term sustainability. Systems that fail to acknowledge and accommodate the tensions they inherit or provoke will have little chance to attract and sustain a broad scale base of users over time - and therefore little chance of rising (or sinking) to the level of infrastructure [5].

\section{References}

[1] Barro R. "Government Spending in a Simple Model of Endogenous Growth" (2012). Journal of Political Economy, Vol. 98, No 5, pp. 102-125.

[2] Jeon, C M; Amekudzi (March 2005), "Addressing Sustainability in Transportation Systems: Definitions, Indicators, and Metrics", Journal Of Infrastructure Systems: p.31-50

[3] White Paper on Transport (2011), Luxembourg: Publications Office of the European Union, p. 32

[4] Donald J. Bowersox, David J. Closs, M. Bixby Cooper, (2009), Supply Chain Logistics Management, McGraw-Hill, p. 498

[5] Paul N. Edwards, Steven J. Jackson, Geoffrey C. Bowker, Cory P. Knobel, (2007), Understanding Infrastructure: Dynamics, Tensions, and Design. Report of a Workshop on "History \& Teory of Infrastructure: Lessons for New Scientific Cyberinfrastructures", University of Michigan, Ann Arbor. http://hdl.handle.net/2027.42/49353. 


\section{THEORETICAL APPROACHES TO THE DEVELOPMENT OF THE PRODUCTIVE FORCES OF UKRAINE REGIONS IN THE MODERNIZATION DIMENSION}

\section{O. Popelo ${ }^{1}$}

\section{Abstract}

The author's definitions of the concepts "region", "regional economic space", "modernization of productive forces" are given in the article. It is proposed to determine the level of modernization of productive forces by analyzing its components: the level of the modernization state of the economic sphere, the level of the modernization state of human development and the modernization state of the environmental sphere.

Keywords: region, regional economic space, regional development, productive forces, modernization.

The effectiveness of the regional development in the context of increasing the country's integration into the global economy is directly dependent on the organization of processes management of the productive forces modernization of the regions of Ukraine.

Today, regional studies have many directions, but all of them are based on key theories and concepts of regional development and space teachings and its significance in the economy. Analysis of theoretical approaches to the development of productive forces, as a dynamic, closely related process with the natural, economic and social conditions of economic regions, forms a comprehensive, spatial perception of the economy, taking into account the achievements of scientific and technological progress and the dominant role of the human factor in all spheres of social production.

In modern scientific publications, which form the branch of development of productive forces and the regional economy, almost the most attention was drawn to the concepts of "regional economic space", "regional economic system", "region" and the identification of patterns of territorial development

In our opinion, the region should be understood as the integral component of the single space of the country, characterized by its economic and geographical location, homogeneous natural resource potential, specialization of the sphere of material production and infrastructure development, interrelated historical, ecological, ethno-cultural characteristics and institutional base and economy, the basis of which is the effective and rational use of local factors of production.

We believe that the regional economic space is the aggregate of relations between the objects united by economic interests and the subjects of the market environment, whose interaction is directed at the use of spatial features in the process of reproduction of labor, ensure the production, distribution, exchange and consumption of material goods and services with a view to solving tasks of social and economic development.

Scientific researches confirm that in the era of information development of society the main productive force is a creative person.

\footnotetext{
${ }^{1}$ Olga Popelo, Candidate of Economic Sciences, Associate Professor, Chernigov National University of Technology, Ukraine.
} 
In the first place among the categories characterizing the productive forces come knowledge that has an ideal and material embodiment: in education, technology, production qualification of specialists, as well as in new technology, organizational systems, products and services. [1].

The specifics of modern transformational processes occurring in regional economic systems, as well as the trends in the development of the world economy and the existing global problems of mankind, actualizes the question of the development of productive forces in the modernization dimension.

In our opinion, modernization of the productive forces is a system of strategic measures of organizational, economic and innovative nature aimed at the introduction of progressive methods of the production process, improving the technical and operational qualities of fixed production assets and their technical and technological re-equipment, the effective use of intellectual potential with active involvement of the human creativity with its inherent educational and qualification characteristics, rational use of which in combination with other economic resources ensures achievement of new quality of the economic development of the productive forces.

In order to assess the level of modernization of productive forces, we propose to analyze its components, such as: level of modernization of the economic sphere, level of modernization of human development and modernization of the environmental sphere (Table 1).

Table 1

Component indicators assessing the level of modernization of productive forces $[4,5]$

\begin{tabular}{|c|c|}
\hline Index & Indicator \\
\hline \multirow{3}{*}{$\begin{array}{l}\text { Level of modern- } \\
\text { ization of the } \\
\text { economic } \\
\text { sphere }\end{array}$} & $\begin{array}{l}\text { The level of economic development: } \\
\text { - share of sold industrial output in GRP; } \\
\text { - share of production of agricultural products in GRP; } \\
\text { - coefficient of export coverage of imports; } \\
\text { - share of services rendered in GRP; } \\
\text { - income of population per } 1 \text { person; } \\
\text { - level of efficiency of use of fuel and energy resources }\end{array}$ \\
\hline & $\begin{array}{l}\text { Investment activity level: } \\
\text { - share of investment in fixed assets in GRP; } \\
\text { - foreign direct investment per capita }\end{array}$ \\
\hline & $\begin{array}{l}\text { Level of innovation activity: } \\
\text { - share of sales of innovative products in the GRP; } \\
\text { - share of innovative enterprises in the total number of industrial enter- } \\
\text { prises; } \\
\text { - share of sales of innovative products in the total volume of sales of indus- } \\
\text { trial products in the region }\end{array}$ \\
\hline $\begin{array}{l}\text { Level of modern- } \\
\text { ization of hu- } \\
\text { man develop- } \\
\text { ment }\end{array}$ & $\begin{array}{l}\text { - level of reproduction of the population } \\
\text { - level of comfort of life of the population } \\
\text { - level of material maintenance of the population } \\
\text { - level of employment of the population } \\
\text { - level of education of the population } \\
\text { - level of scientific activity of the population }\end{array}$ \\
\hline $\begin{array}{l}\text { Level of modern- } \\
\text { ization of the } \\
\text { ecological } \\
\text { sphere }\end{array}$ & $\begin{array}{l}\text { Integral indicator of the state of the environment: } \\
\text { - indicator of the state of land resources } \\
\text { - indicator of the state of water resources } \\
\text { - an indicator of the state of atmospheric air }\end{array}$ \\
\hline
\end{tabular}


Conclusions. In contemporary conditions of economic development due to the active scientific position of regional scientists, which provide a constant flow of research, new and modernized classical theories and concepts for the development of productive forces and regional economics continue to emerge. With the rapid development of innovations, computer technologies, know-how and others new development theories, taking into account the researches of the classics of localization of agricultural and industrial production and their followers, focus on other types of activity and location factors. The emphasis is moves from traditional factors (material, labor, transport costs) to intangible factors (generation, storage and transfer of knowledge and information), which are more difficult to quantify, hence the need to create new information and analytical tools.

\section{References}

[1] Butnik-Seversky, A. (2007) Innovation and the knowledge economy (theoretical and methodological aspects). Theory and practice of intellectual property. № 6. pp. 68-81.

[2] Heyets, V., Semynozhenko, V. (2006) Innovative perspectives of Ukraine. - Kharkiv: Constant, 2006, $272 \mathrm{p}$.

[3] Zharova, L. (2011) Structurally-dynamic theory of the placement of productive forces: theoretical and methodological approaches to formation. Economy and the state, №12, pp. 18-22.

[4] Popelo, O. (2017) Methodological approaches to modernization processes of the productive forces in the conditions of Eurointegration. Scientific bulletin of Polissya, № 1 (9). p. 1, pp. 218-224.

[5] Popelo, 0. (2016) Methodological approaches to assessing the level of modernization of productive forces. Bulletin of Odessa National University, Economics chapter. Vol.71 (49), pp. 109-113. 


\section{THEORETICAL ASPECTS OF FORMATION AND DEVELOPMENT OF FINANCIALISATION OF REGIONAL ECONOMIC SYSTEMS}

\section{O. Treytyak ${ }^{1}$}

\section{Abstract}

The globalization of the economy and its dependence on the financial sources of the acceleration of reproductive processes are at the center of attention of modern economic science. The importance of the direct influence of financialization on the activation of the development of productive forces and of the regional economy combined with the intensification of integration processes with the simultaneous necessity of reducing transaction costs actualize the modernization aspects of spatial development of the economy. in modern conditions.

Keywords: globalization, economy, finance, region, real sector, financial sector, mezzanine.

The deepening of the gap between the real and financial sectors of the economy leads to an increase in the unpredictability and asymmetry of their development, the curtailment of innovation and investment processes, the manifestation of crisis phenomena and the acceleration of the dynamics of economic cycles.

These processes are particularly acute in the functioning of regional economic systems, since the need for financial consolidation on the meso-level requires an elastic combination of it with the state's strategy for decentralization and increasing the self-sufficiency of territorial communities and their associations.

The influence of the spatial factor on the efficiency of the functioning of the economy and the formation of qualitative, structural and innovative transformations at the regional level is determined in the report of the World Bank and materials of the World Economic Forum.

The problems of the sectoral development of the regional economy are devoted to a significant number of scientific works of such foreign scientists as: R. Dore, A. Epstein, JM Keynes, G. Corinne, G. Kripner, Pierre Yves Galese, S. Strandj, J. Sorosh, J.-P. Servan-Schraider, K. Taleb, M. Hudson, R. Hilfred, N. Phillips, J. Schumpeter and many others. Among the domestic scientists, this problem was investigated: O.M. Alimov, OI Amosha B.V. Burkina, MP Butko, VM Vasilenko, Z.S. Varnal, KO Vashchenko, VP Vishnevsky, V.E. Vorotin, VM Heyets, OI Гонта, Б.M. Danylyshyn, AI Danilenko, MI Dolishniy, SI Doroguntsov, P.S. Yeshchenko, VI Zakharchenko, L.L. Kovalska, VP Microwell, IZ Storonianska, T.V.

\footnotetext{
${ }^{1}$ Olga Treytyak, Candidate of Sciences (Economics), Chernigiv National Technological University, Ukraine.
} 
Pepa, VP Udovychenko, LG Chernyuk, MG Chumachenko, AA Chukhno SM Scarlett and others.

Despite the considerable scientific advances in addressing regional development problems, the peculiarities of the impact of financialisation on the modernization of productive forces and the balance of the regional economy remain insufficiently studied.

The problems of interaction between the financial and real sectors of the economy are among the scientific interests of many foreign and domestic scholars and scientific schools. The separation of the financial market from the real economy was investigated in the works of K. Marx [7]. More complete theoretical foundations of economic relations between the financial and real sectors of the economy were disclosed in R. Hilferding's work [1], Dzh.M. Keynes [3], H. Minsky [15], J. Schumpeter [14]. Summarized the content of the financial market in the economic system and its subjective-object structure on the basis of the traditional paradigm, disclosed in the writings of these researchers is presented in Drawing. 1.

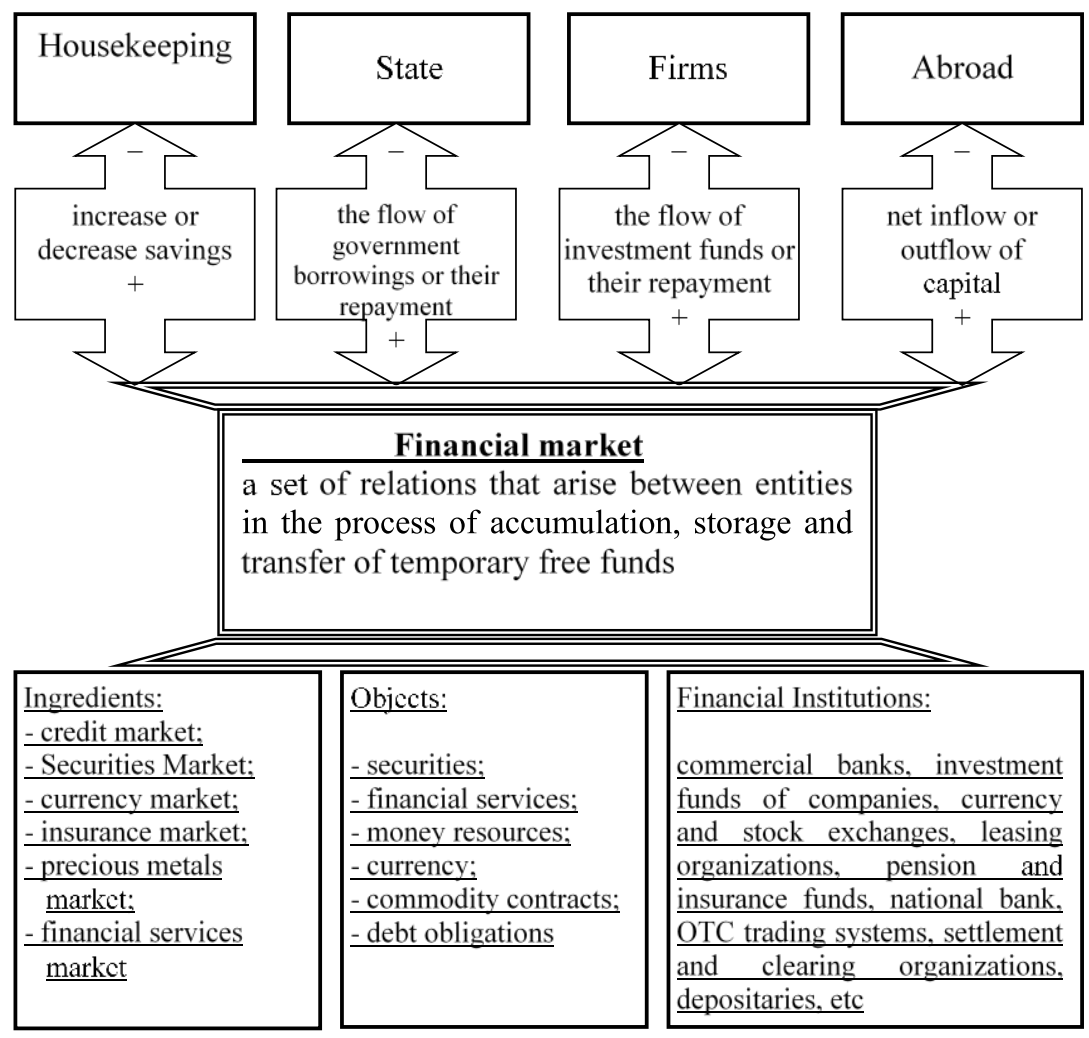

Drawing 1. Traditional idea of the place of the financial market in the economic system 
The aforementioned point indicates that the majority of researchers based on positive trends in the development of a real economy at maro-, meso- and macro levels sees the role of the process of financialisation. This role should have a positive effect, as the financial sector contributes to increasing savings and their transformation into investment, but today there is the opposite situation - the outflow of finance from the real economy, the growth of bank risks, the asymmetry of development, the deepening of the cyclical development of the economy, the outflow of investments of individuals etc. These negative trends emerging at the national level are particularly acute in the functioning of regional economic systems, since the need for financial consolidation on the meso-level requires its elastic combination with the state's strategy for decentralization and increasing the self-sufficiency of territorial communities and their associations.

It should be noted that the main task of the financial sector on the mezzanine is to increase the potential of the region, improve the socio-economic indicators of its functioning, create conditions for the growth of capital and its rational distribution in economic spheres, bear responsibility for cash flow and redistribution of risks.

The peculiarity of the financial sector is that it is the most important driving force in establishing a stable economy of the country and its regions, increasing the competitiveness of the real sector of the economy and ensuring the welfare of the population.

The financial sector has the opportunity to act not only as a priority resource for investment in the real sector, but as an independent part in enhancing social and economic development, by creating new jobs and reducing asymmetry in regional development.

In general, scientists traditionally consider the main task of the financial sector to be accumulation, accumulation, transformation and redistribution of funds among economic agents. But over time, the function of this sector is expanding. So they started to include emission, stabilization, security and investment functions, that is, in the modern economy, the financial sector should be closely interconnected with the real sector of the economy.

However, a number of scholars questioned the above substantiated thesis that the key factor in economic development is the financial sector itself. Thus, Vine Simon in his monograph states that the development of the financial market can have both positive and negative consequences. On the one hand, the financial market contributes to a stable and stable development of the economy, on the other hand - due to the appearance of "financial bubbles" - it can lead to more destabilization.

Positive and negative influences of the financial sector on the real one are also considered in the works of well-known economists and politicians. For example D. Adams noted the negative role of banks in the development of both national production and nation [12].

In the environment of domestic scientists, the scientific interest in these issues was formed relatively long ago. The reason for this situation is that the development and formation of the dominance of the financial sector over the real, has started far beyond the economic territory of our state (in the US and 
Europe), but with the deepening of globalization processes and global economic transformations, the development of financial innovations has become widespread and important in others. countries.

Among native scholars, N.Grazhevsky [2], M. Korneev [4], V. Lukyanov [5], I. Lyuty [8], D. Morozov [6]) began to study the essence, content and influence of financialisation on the economy., N. Shchepochkin [9] and others.

An overview of literary sources revealed that the interpretation of the notion of financialisation depended not only on the level of research, but also on the outcome of the process's impact on the growth of the economy.

Yes, Gerard Epstein defines financialisation not only as a process of increasing shareholder value, but also a key factor in corporate governance and the domination of the financial market in the capital market [10].

In his turn, Gretta Cripner points out that financialisation serves as the main form of capital accumulation and profit, not because of trade in goods or their production, but through financial channels, which in turn reduces operating costs [11].

In the American research community, the roots of the financialisation process have been investigated, Milton Friedman and scholars from the Chicago School have come to the conclusion that the process originates from neo-liberalism and the emergence of a market economy that has provided the ideological and theoretical basis for increasing deregulation of the financial system and banks. David Rakcio, believes that the process of financialization was initiated during the period of property creation and the reduction of state control [13].

Summarizing the aforementioned theoretical approaches to the content of definitions related to the functioning of the financial sector of the economy, we suggest considering financialisation as a process in which financial markets, financial institutions and elites have a significant leverage effect on the country's economic policy and its results.

The main features of financialisation at different levels of the economy are:

- the predominance of the role and significance of the financial sector over the real;

- redistribution of income from the real to the financial sector;

- Increased income asymmetry and stagnation of wages.

In addition, there are every reason to believe that financialisation can put the country's economy under fractional deflation and recession.

Thus, it can be argued that the financialization process is positive in the beginning of activity, which is accompanied by an increase in the negative impact on the economic situation with the deepening of financialisation processes. Therefore, only by analyzing the mistakes of the process's impact on the economies of developed countries and adapting them to their own model, we can achieve a stable and sustainable economic development, using the potential benefits of financialisation.

The aforementioned theories are not perfect, since their use requires stability of the financial situation in the country and regions, reducing the influence of the shadow economy on the financial sector, and the availability of reserve funds. 
After reviewing the data of theories, we can conclude that the finances of the region are not only one of the components of local authorities, but also play a leading role in the development of the system of its economic relations.

That is, the finances of the region may be regarded as an objective form of economic relations, which is associated with the distribution and redistribution of the value of the GRP, in the process of which the formation and use of funds of funds are being used, which are intended to meet the needs of the region. Hence, uncontrolled use of financial resources in the region could lead to negative consequences such as inappropriate use of resources, aimed not at the development of investments in the real sector; inefficient functioning of the internal market; increasing asymmetry between regions; concentration of funds in large cities.

Thus, it can be argued that the assessment of the effects of financialisation has a number of contradictions. On the one hand, an increase in the influence of the financial sector is a driver of the positive dynamics of changes in the development of the economy, on the other - the functions assigned to the financial sector, savings, emissions, investments, lending is not performed in full. And the excessive increase in the number and types of financial instruments led to the separation of nominal asset prices from real ones.

It is also worth noting that the decline in real production negatively affects the economy, due to lower revenues to the budget, which in turn leads to a decrease in economic activity and the need to attract funds in the framework of financing the budget deficit.

Having investigated the genesis of scientific views on the essence of the financial resources and financial capacity of the region, we propose, in the framework of our study on financialisation, to understand the system of economic relations aimed at sectoral separation of a specific area of services related to the concentration, priority orientation and effective use of the financial potential of territorial units in the interests of their development on the basis of sustainability (Drawing 2).

Continuing the opinion of Professor M. Korneev, we can also note that financialisation within the regional economic system will be manifested by the following trends:

- in the behavior of the entrepreneurial sector: enterprises, their free capital, instead of investing in their own production, direct them to profitable financial transactions, turning to a certain extent in financial institutions, financializing;

- in the behavior of elements of the financial sector: banks are beginning to focus more on open market operations and business with households than on traditional money transactions;

- in the behavior of households: the activation of participation in financial activities of households (in insurance, pensions, etc.), that is, the behavior of individual individuals are beginning to dominate financial motives;

- in the behavior of state authorities and local self-government: activation of participation in conducting financial transactions with the purpose of forming the budget of the corresponding level; 


\section{Financial Regionization:}

the system of economic relations aimed at the sectoral separation of a specific sphere of services related to the concentration, priority orientation and effective use of the financial potential of territorial units in the interests of their development on the basis of sustainability as a phenomenon - changes in the structure of social production of the regional economic system associated with the domination of the financial sector

as a process - the process of strengthening the dominance of the financial sector over other economic systems in the region, which creates favorable conditions for the inclusion of all economic agents in the financial market, accompanied by the transformation of financial capital into fictitious and virtual and the distancing of the financial sector from the production

as a product - a product of globalization and integration processes, which is conditioned by the development of the financial sector and the accumulation of financial resources, which eventually separates from the material production of the regional system

as relations - a set of socio-economic, organizational and economic relations that arise between economic entities on the mesolevel, in relation to the formation, distribution and use of credit and financial resources

Drawing 2. The essence of financialisation of the regional economic system

- in the behavior of the economic system of the region: the rapid expansion of the share of financial sectors, the rapid pace of implementation of financial innovation, the flow of capital from the real sector into financial, the growth in the number of operations with fictitious capital against the background of the liberalization of financial relations.

Modernization of the regional economic space and its composition of the financial services market, as catalysts for the development of productive forces on the meso-horizon, promotes the emergence of a new tool - financial innovation in their structure.

In our opinion, financial innovation is the result of the introduction of new innovations in the regional services market, embodied in the form of a new or improved product, technology, as a catalyst for the adaptation of the regional economic system to the requirements of European integration. 


\section{References}

[1] Gilferding, R. Financial Capital / R. Gilferding. - M., Finance and Statistics, 1959. $358 \mathrm{p}$.

[2] History of Economic Students: [taught. Manual.] / Structure. [V.D. Bazilevich, N.I.Grazhevskaya, A.O. Maslov et al.]; for ed. VD Bazilevich - K.: Knowledge, 2011. $-1198 \mathrm{p}$

[3] Keynes, J. General theory of employment, interest and money. Favorites / J. Keynes. - M .: Exmo. Series "Anthology of Economic Thought", 2007 - 960 pp.

[4] Korneev M.V. The Influence of Economic Financing on the Level of Satisfaction of Some Social Needs / MV Korneev // Bulletin of the Khmelnitsky National University. Series "Economic Sciences" - Khmelnitsky, 2014. - No. 4, T.1 (214). - P.211219.

[5] Lukyanov, VS Financialization as a manifestation of globalization transformation / VS Lukyanov // Current problems of the economy. - 2013. - No. 4 (142). - P. 1523.

[6] Lyuty I.O., Moroz P.A. Contradictions in the processes of financialisation and their impact on economic growth in Ukraine // Economy of Ukraine - 2014 - No. 4, pp. 29-39

[7] Marx, K. Capital. Criticism of political economy. Works: T. 25 / Karl Marx, Friedrich Engels. - M .: Publishing House of Political Literature, 1978. - $1200 \mathrm{p}$

[8] National financial systems in the conditions of globalization: monograph / [I.0. February, AF Pavlenko, T.E. Obolenskaya and others.]; per community Ed. IO February - Ivano-Frankivsk: Galician Academy, 2008. - 306 p

[9] Shchepokchina, NA The features of unification of the standards of regulation of the world financial market [Electronic resource] / N. A. Shchepochkina // Conference "Lomonosov", 2011. - Access mode: http://lomonosov-msu.ru/archive/ Lomonosov_2011 / 1410/13300_1890.pdf

[10] Epstein, G. Financialization, Rentier Interests, and Central Bank Policy, manuscript [Electronic resource] // Department of Economics, University of Massachusetts. - Amherst, MA, 2001. - Access : http://www.peri.umass.edu \%2 Ffileadmin \%2Fpdf \%2Ffinancial \%2Ffin_Epstein.pdf.

[11] Krippner, G. The Financialization of the American Economy / Greta Krippner // Socio-Economic Review. - 2005. - Vol. 3, Issue 2. - P. 173-208

[12] Lapavitsas, C. Financialised Capitalism: Crisis and Financial Expropriation / // Historical Materialism. - 2009. - №17 (2). - P. 114-148.

[13] Freeman, R. It's financialization! / R. Freeman // International Labor Review. 2010. - Vol. 149, Issue 2. - P. 163-183.

[14] Schumpeter, J. A. Theorie der Wirtschaftlichen Entwicklung. Leipzig: Dunker \& Humblot, 1912 / Joseph A. Schumpeter // The Theory of Economic Development, translated by R. Opie. - Cambridge, MA: Harvard University Press, 1934

[15] The Financial Instability Hyposesis / Hyman P. Minsky // The Jerome Levy Economics Institute of Bard College. Working Paper. - 1992. - № 74. - $10 \mathrm{p}$ 


\section{ORGANIZATIONAL FORMS OF INNOVATION ACTIVITY}

\section{O. Shevchenko ${ }^{1}$}

\section{Abstract}

Forms of activation of innovative development of the region including: innovation centers, industrial parks, clusters are investigated. The tendencies of development of industrial parks in Ukraine are analyzed.

Keywords: innovative development, innovation centers, industrial parks, clusters, local government, public-private partnership.

Одной из эффективных форм активизации инновационного развития региона являются инновационные центры, которые в своей деятельности эффективно сочетают сотрудничество промышленных фирм с высшими учебными заведениями. Это технологически активные комплексы со сложившейся интегрированной структурой нововведений, которая включает университеты и научно-производственные фирмы. Сейчас во Львовской области функционирует «Львовский Государственный центр науки, инноваций и информатизации». Основная его деятельность направлена на проведение патентно-информационных и социологических исследований. Он занимается проведением фундаментальных и прикладных исследований по проблемам развития интеллектуального потенциала, организации научно-инновационной и информационной деятельности, оценивает инвестиционную привлекательность объектов и т.д. [2, с. 30-31]. Эффективность деятельности научных парков оценивается успехами связанных с ними фирм. Процент ликвидации фирм по истечении двух лет их существования в лучших парках США не превышает 20\%, тогда как вне парков перестают функционировать до 60\% новых создаваемых единиц.

Отдельно необходимо сказать об индустриальных парках в Украине. В соответствии с Законом Украины "Об индустриальных парках" индустриальный парк (ИП) - это обустроенная соответствующей инфраструктурой территория, в пределах которой участники ИП могут осуществлять: -хозяйственную деятельность в сфере перерабатывающей промышленности; - научно-исследовательскую деятельность; - деятельность в сфере информации и телекоммуникаций и т.д. [3, с. 2].

Инициаторами создания ИП могут быть: - органы государственной власти; - органы местного самоуправления; - юридические или физические лица - собственники земельного участка частной собственности; - юридические или физические лица - арендаторы земельного участка по землям государственной, коммунальной и частной собственности. Для получения

\footnotetext{
${ }^{1}$ Oleg Shevchenko, Candidate of Economic Sciences, Associate Professor, Chernihiv National University of Technology, Ukraine.
} 
субъектами ИП государственной поддержки, предусмотренной законодательством, соответствующий ИП должен быть включен в Реестр ИП.

Государственная поддержка создания и функционирования ИП предусматривает: - направление средств Государственного фонда регионального развития на финансирование проектов создания инфраструктуры индустриальных парков при условии софинансирования из местных бюджетов на уровне $10 \%$ от их сметной стоимости; - освобождение от долевого участия в развитии местной инфраструктуры в случае строительства субъектами ИП объектов в пределах соответствующих ИП; - освобождение от уплаты ввозной пошлины при ввозе субъектами ИП оборудования и комплектующих к нему, материалов, которые не производятся в Украине, и ввозятся с целью обустройства ИП и осуществления в их рамках хозяйственной деятельности.

Субъекты ИП также могут воспользоваться другими инструментами и механизмами, предусмотренными законодательством, в частности: - освобождение от уплаты ввозной пошлины; - ввоз по льготным ставкам ввозной пошлины (до 0\%) товаров, происходящих из государств - членов ВТО, или из государств, с которыми Украина заключила двусторонние или региональные соглашения о режиме наибольшего благоприятствования, в т. ч. с ЕС и Канадой; - ввезение без уплаты ввозной пошлины оборудования [3, c. 6].

Местная поддержка индустриальных парков в Украине предусматривает:

- предоставление по решению органов местного самоуправления льгот по земельному налогу и налогу на недвижимое имущество для субъектов ИП, которые учитывают общественные интересы, отраженные в программных документах экономического и социального развития; - установление государственными органами и органами местного самоуправления минимальной арендной ставки за аренду земель государственной и коммунальной собственности; - содействие на местном уровне оформлению всех разрешительных и иных документов, необходимых для реализации проектов; выделение средств из местного бюджета для финансирования работ по обеспечению инженерной инфраструктурой определенных земельных участков или создание условий для доступа к этим участкам; - организационная и финансовая участие в наборе и организации обучения потенциальных и действующих сотрудников компаний-субъектов ИП [3, с. 7].

С 2013 года в соответствии с Законом Украины «Об индустриальных парках» инициировано создание 29 индустриальных парков, из которых 22 - включено в Реестр индустриальных парков. По состоянию на 31.05.2017 в Украине также функционирует 6 частных индустриальных парков, которые не включены в Реестр индустриальных парков. Местными органами исполнительной власти, органами местного самоуправления и частными субъектами прорабатываются вопросы по созданию новых индустриальных парков в Запорожской, Закарпатской, Житомирской, ИваноФранковской, Львовской, Николаевской, Ровенской, Херсонской, Черниговской, Черновицкой, Черкасской, Кировоградской областях и в г. Киеве. 
Право собственности на земельные участки, на которых созданы индустриальные парки: 22\% - частная, 8\% - государственная, $8 \%$ - смешанная (коммунальная и частная), 62\% - коммунальная [3, с. 8].

Перечень индустриальных парков, включенных в Реестр индустриальных парков: 1. «Долина» (г. Долина, Ивано-Франковской обл.), 2. «Славута» (г. Славута, Хмельницкой обл.), 3. «Обильное-2» (г. Львов), 4 «Коростень» (г. Коростень, Житомирской обл.), 5. «Центральный» (г. Кременчуг, Полтавской обл.), 6. «Свема» (г. Шостка, Сумской обл.), 7. «Соломоново» (с. Соломоново, Закарпатской обл.), 8. «Первый Украинский индустриальный парк» (поселок Большая Александровка, Киевской обл.), 9. BIONIC Hill (г. Киев), 10. iPark (Коминтерновский район, Одесской обл.), 11. Индустриальный парк «Кривбасс» (г. Кривой Рог, Днепропетровской обл.), 12. Индустриальный парк «Тростянец» (г. Тростянец, Сумской обл.), 13. Индустриальный парк «Мироцкое» (Киевская обл.), 14. Винницкий индустриальный парк (г. Винница), 15. Индустриальный парк «ЖИТОМИР-ВОСТОК» (г. Житомир), 16.Индустриальный парк «Новоднестровск» (г. Новоднестровск Черновицкой обл.), 17. Индустриальный парк «Фастиндастри» (г. Фастов, Киевской обл.), 18.Индустриальный парк "Павлоград" (Павлоградский р-н, Днепропетровская обл.), 19. Яворивский индустриальный парк (Яворовский р-н, Львовская обл.), 20. Индустриальный парк «Золотоноша» (г. Золотоноша, Черкасская обл.), 21. Каменка-Бугский индустриальный парк (г. Каменка-Бугская, Львовская обл.), 22. Индустриальный парк «Винницкий кластер холодильного машиностроения» (г. Винница) [3, с. 10].

В соответствии с Законом Украины «Об индустриальных парках»и Положения, утвержденного постановлением Кабинета Министров Украины от 20.08.2014 № 459, формирование и реализацию государственной политики по созданию и функционированию индустриальных парков в Украине осуществляет Министерство экономического развития и торговли Украины [3, с. 11].

В 1990-х годах в государственной инновационной политике начинает приваливать кластерная философия - правительство концентрирует усилия на поддержке существующих кластеров и создании новых сетей компаний, ранее не контактировали между собой.

Достижения взаимного соответствия различных сфер предпринимательства во многом зависит от налоговой, бюджетной и внешнеэкономической политики. Их роль возрастает в вопросах разработки и реализации планов необходимого технологического обеспечения национальных потребностей, согласованными изменениями политики стандартизации, установление взаимодействия крупного и малого бизнеса, регулирование естественных монополий и тому подобное.

Использование различных внутрифирменных и межфирменных организационных форм инновационной деятельности на региональном, отраслевом, корпоративном уровнях является характерной особенностью современного этапа развития научно-технического прогресса, которая способствует ускорению инновационных процессов, быстрому овладению обществом результатов инновационной деятельности и коммерческом 
успехе всех участников межгосударственной и межфирменной кооперации $[1$, c. $255-264]$.

\section{References}

[1] Захарченко В. І. Інноваційний менеджмент: теорія і практика в умовах трансформації економіки [Електронний ресурс] / В. І. Захарченко, Н. М. Корсікова, М. М. Меркулова. - К.: Центр учбової літератури, 2012. - Режим доступу: http://culonline.com.ua/Books/Innovaciyniy_menedgment_Zaharchenko2012.pdf.

[2] Луцків О. М. Сучасні організаційні форми інноваційної діяльності: регіональний аспект / О. М. Луцків. // Науковий вісник Полтавського університету економіки і торгівлі. - 2015. - № 1. - С. 29-34.

[3] Офіційний сайт Міністерства економічного розвитку і торгівлі України [Електронний ресурс]. - Режим доступу: http://www.me.gov.ua/Documents/List?lang=uk-UA\&id=6463d3ba-aa13-4e548db9-0f36642c43d9\&tag=IndustrialniParkiVUkraini. 


\title{
CHINESE RENMINBI INTERNATIONALIZATION AND POSSIBLE EFFECTS FOR HONG KONG STOCK EXCHANGE MARKET
}

\section{Biryukov¹, M. Zhiyenbayev²}

\begin{abstract}
The article is a research on Chinese Political Economy, dealing about renminbi Internationalization and its effects on Hong Kong Stock Exchange. Hong Kong is an ideal stage to measure perceptions of benefits underpinned to Renminbi (RMB) internationalization. In fact Hong Kong is part of People's Republic of China as a Special Administrative Region and benefits from this situation, having particular political and economic autonomies. In particular Hong Kong has its own currency and political economy and can deal with Chinese economy from the particular position of an external insider. Hong Kong is also the first market where have been issued bonds in Renminbi and is probably going to become the most affected economy from the internationalization. An analysis of possible real benefits (or negative effects) that Hong Kong and its population could have from an internationalized RMB taking in account effects of Chinese step toward Internationalization on Hong Kong finance market.
\end{abstract}

Keywords: Renminbi, China, Hong Kong, US Dollar.

While the world is facing the end of the economic crisis started in 2008, financial crisis is probably not near to a resolution. The European Union is still under a negative finance situation. China is protagonist of a positive recovery from the crisis finance crisis started in 2009 and has consolidated its role of second world economy (even with a revised GDP). The People's Republic of China policy of Renminbi Internationalization has made big progress from 2009 onward, probably also because PRC and People's Bank of China are trying to take advantage from impasse caused on US Dollar and Euro from the crisis. Internationalization of Chinese currency it's having and will have huge effects on Hong Kong HUB (one of the principal Stock Market worldwide).

Renminbi Internationalization:

First steps. At the end of 2003 Central Bank of China started to work toward RMB internationalization and in 2004 China started to allow border trading of money, especially through Southern and Western border. Since that date Chinese Central Bank started a policy to apt and adapt its money to be exchanged in International markets [1]. In fact internationalize a money is the process through which a State and its Central Bank get its currency apt to be used outside its borders.

\footnotetext{
1Valeriy Biryukov, Doctor of Economic Sciences, Professor, Karaganda State Technical University, Kazakhstan.

${ }^{2}$ Miras Zhiyenbayev, student, Karaganda State Technical University, Kazakhstan.
} 
The first step took place in 2000 with the Chiang Mai Initiative and the signing of the bilateral agreement between the ASEAN countries and the three East Asian Major economies: South Korea, China and Japan. Most of the exchanges planned by the treaties were effected in US dollars, but some of them also in RMB [2]. So we can affirm that China around 2000 years started to conceive its role of hegemonic regional economy to understand that internationalized money was one of the first step to fulfill this role.

Main benefits that China could obtain from the Renminbi internationalization are 1) To reduce the change risk for Chinese enterprises operating abroad, for example in European market [3]. 2) To incentivize and sustain Chinese FDI outflows [4]. 3) To enter its currency in the official basket of currencies used to quote the SDR, actually China would need this capability to play a bigger role in the International Political Economy obtaining a greater autonomy in international monetary affairs.

First and second points have become more and more important starting from 2005 [5], when China increases its interests in trading with European economies. Particularly China, as a lot of analysis suggest, [6] established with EU a number of "asymmetric competions" in market. China and Chinese enterprises used basically three tactics to operate in EU markets [3]. First is to take advantage of differences between its own centralized authority and the EU's rules-based system. In fact, China makes full use of the openness of EU markets while using fragmentation of its own administrative channels is able to restrict access (even with non-tariff barriers) to its own market to the European Union firms [3]. The internationalization of RMB would make Chinese firms gain the confidence of European States (for having liquidity in internationalized currencies) but they actually wouldn't maintain the protection of the political Chinese apparatus.

Second Chinese tactic is based in assuring EU on its opening to questions as general human rights and opening to market economies, in effect, as quoted from Fox and Godement "EU hails as a great victory the opening to human rights dialogue with China" [3]. A bigger victory for EU and Western markets in general will be, at the same way, the perception of opening to finance markets realized with RMB internationalization.

Third factor used by China would be to have a strong and international currency and autonomous monetary policy, renouncing fixed rates of exchange. Third point to examine is the Chinese awareness of importance of Renminbi entrance in the "club" of currencies used by IMF to quote SDR. This basket encompasses Euro, US dollar, Sterling pound and Japanese Yen. The currency value of the SDR is determined by summing the value in US dollars of the currencies of this basket. IMF and generally international finance system recognize the currencies of the basket as the "major currencies" [7]. China realized to be one of the leading economy and its need to be part, with RMB as major currency, of IMF system after the 1997-1998 crisis, with its entrance in WTO in 2001 and during $\mathrm{Hu}$ Jintao Era. In fact in 2009 China Central Bank Governor, Zhou, started to talk about SDR in a relevant contribution appeared in People's Bank of China website. China need an international Renminbi to be in a directive position in the finance 
world. Chinese position in financial community has then become much more important after the 2008 International crisis and a partial "erosion" of US dollar role [8].

Actions toward an RMB Internationalization. In 2004 Chinese government started to allow cross border money trading (first step toward the currency internationalization). Political opinions on RMB internationalization are generally positive either for neoliberal thought [8] and non-liberal thought [9]. In effect even recent scholarship suggests that this positive view is right. One of $t$ conventional view is that there can only be one international reserve currency at a point in time. Recent historical scholarship shows, to the contrary, that several international currencies have regularly coexisted. But there is no reason why, in the circumstances of the 21st century, the dollar and the RMB could not both play major global roles. There is no reason why the US should continue to possess a monopoly in international finance without starting another International financial crisis [1].

A first acceleration in the project was made with the creation of "dim sum bond market". The definition "dim sum bond" generally is related to RMB-denominated bonds issued in Hong Kong. The majority of dim sum bond are denominated in $\mathrm{CNH}$, but some are linked to RMB and quoted in that currency. In July 2007, dim sum bonds worth a total of US\$657 million were issued for the first time by China Development Bank. These bonds were issued to foreign investors in Renminbi, for first time, rather than the local currencies.

One of the biggest evolution was in August 2012, in that year China and Taiwan signed an memorandum of understanding on new cross-strait currency settlement and in March 2013, China Trust Commercial Bank became the first to issue RMB bonds in Taiwan market (known as Formosa bond). Political issues were overpassed for PRC needing to internationalize RMB. By 2014, RMB crossborder trade settlement reached RMB 5.9 trillion making a 42.6\% (YoY) increase, which represent $22 \%$ of China's trading volume.

Third Chinese step toward a future currency internationalization started in 2009: since that year China has signed currency swap agreements with numerous countries such as Argentina, Belarus, Brazil, Canada, ECB, Hong Kong, Iceland, Indonesia, Malaysia, Singapore, South Korea, Thailand, the United Kingdom and Uzbekistan. The Renminbi deposits in Hong Kong gradually grow up and become 59 billion in 2009. As of 2014, the RMB is the 7th most traded currency in the world while US Dollar remains the First one (with $41 \%$ of transactions in USD) [7].

Finally the fourth macro-step in RMB Internationalization was taken from China in 2013: the opening of Shanghai Free Trade Zone (SFTZ). In addiction a deep, open and well-regulated capital markets are necessary so the currency can be used to finance trade as well as provide a large enough market in securities for investors. The opening up of China's onshore capital market will be an important step in the RMB becoming a major investment currency. For the RMB to be a truly global and become a more widely held reserve currency there needs to be greater access for foreign investors to local capital markets, even deeper global RMB liquidity and wider cross-border flow channels. 
Effects of Internationalization in Hong Kong. Hong Kong is a particular case of a mixed sovereignty state from 30th July 1997: when Great Britain governor abandoned the British colony. The return of Hong Kong under Chinese sovereignty marked the success of Deng's concept of "one country, two systems" and combined the Chinese Communist Party control on Foreign Affairs Political aspect and Defense with a large autonomy in Internal Politics and Political Economy, maintaining its own currency, financial market and autonomous political choices. Hong Kong remains one of the biggest finance market and it has been a sort of access for Chinese investors to International finance markets.

Renminbi (RMB) bonds in Hong Kong, with an issue of RMB1 billion (HK\$1.1 billion) bonds by its Mainland branch to institutional investors. For first I examine the principal index of trading: the Hang Seng. The Hang Seng Index (HSI) reached its highest level of the year at 22,943 points on 16 November 2009 and closed the year at 21,872 points, $52 \%$ higher than the previous year's closing. At the end of 2009, the Hang Seng China Enterprises Index (H-shares Index) increased year-on-year by $62 \%$, closing at 12,794 points. The Hang Seng ChinaAffiliated Corporations Index ended the year at 4,059 points, a year-on-year increase of $23 \%$. That happened despite 2009 was immediately successive to the 2008 crisis effect.

Immediate recovery from crisis, due to new trust given to Hong Kong market, especially if compared with Euro countries was probably effect of RMB area swap agreements. A general progress in crisis response was made thank to Chinese dimension of the Hong Kong market, and was helped by the swap agreements [10].

Chinese Enterprises represent biggest group of enterprises listed in Hong Kong market and are an huge resource of capitalization. RMB swap agreements are a mean to facilitate Chinese Enterprises in Hong Kong and we can assess the importance of the agreements considering the increase in number of Chinese Enterprises operating in Hong Kong. In fact Chinese Enterprise passed from 80 in 2005 to 95 in 2006, going to 1042007 and to 110 in 2008 to arrive at 116 in 2009 , after the agreements. This effect was probably created from Chinese Institutions (PBoC) to prepare the Hong Kong market for the agreements and to better convince Hong Kong government in signing them. A positive aspect of increased number of Mainland Enterprises in Hong Kong is the liquidity taken from China to the market.

There is evidence that Chinese swap agreements to prepare their currency internationalization resulted in a series of positive immediate effects for Hong Kong. In fact Hong Kong market lost partially its autonomy to gain an huge liquidity and a number of Chinese finance investors. Furthermore, through the Shanghai-Hong Kong Stock Connect, Hong Kong and international investors are able to invest in eligible shares listed on the Shanghai Stock Exchange, and Chinese investors can invest in eligible shares listed on the Hong Kong Stock Exchange directly. Thank to this new channel Chinese Enterprises are facilitated in investing in Hong Kong and has been created a link between SFTZ and Hong Kong Stock Exchange. 


\section{Conclusion}

There are evidences that for Hong Kong Stock Exchange the Renminbi Internationalization is going to cause an increase in trading, capital flow and capital accumulation. On the one hand a RMB internationalized would cause a huge increase of capital flow in HKSE, on the other hand is going to expose Hong Kong to an excessive linkage with China (diminishing its autonomy in Political Economy) and to the excessive growth risks (as speculative bubbles). Especially if China has not yet the real intention of Internationalize its currency in a relatively short term Hong Kong operators should avoid to concentrate their investment solely in Chinese capitals, bonds and enterprises. In fact basing every investment on Chinese currency will expose too much Hong Kong to an experimental stage (that is, at this moment, the RMB Internationalization) eligible to all the risk of an experiments and not yet solid.

\section{References}

[1] Eichengreen, B., Kawai M., Renminbi Internationalization: Achievements, Prospects, and Challenges, New York, Brooklin Institution Press/Asian Development Bank, 2015.

[2] Otero-Iglesias, M., The Internationalization of the Renminbi: a strategy of crossing the river by feeling the stones, 2011, Oxford, Oxford Brookers University.

[3] Fox, J., Godement, F., A power audit of Eu-China Relations, 2009, Bruxelles, ECFR.

[4] Kang, D., China Rising, 2007, New York, Columbia University Press.

[5] Zhou, X., 2009, "Reform the International Monetary system", 24 March, PBoC, Beijing, from www.pbc.gov.cn/english/detail.asp?col=6500\&id=1

[6] Gabusi, G., Andornino, G., "Prospettive commerciali e tenuta del sistema bancario e finanziario nella Repubblica Popolare Cinese", from Osservatorio di politica Internazionale, n.55 May 2012.

[7] International Monetary Fund, SDR valuation, 2015, from https://www.imf.org/exter$\mathrm{nal} / \mathrm{np} / \mathrm{fin} / \mathrm{data} / \mathrm{rms} \_$sdrv.aspx .

[8] Eichengreen, B., Out of the Box thoughts about the International Finance Architecture, IMF Working Paper, n.116, 2009, New York, IMF.

[9] Subacchi, P., Make Way for the RMB, from Foreign Policy, 16 June 2015, access online http://foreignpolicy.com/2015/06/16/make-way-for-the-rmb-china-reserve-currency-imf-sdr-dollar/?wp_login_redirect=0.

[10]Hong Kong Stock Exchange, Annual Fact Book, 2000-2014, from https://www.hkex.com.hk/eng/index.htm . 


\section{THE PROBLEMS OF LEGALIZATION OF PARALLEL IMPORTS IN RUSSIA}

\section{A. Salnikova ${ }^{1}$}

\section{Abstract}

The article explores the problems of legalization of parallel imports in the Russian Federation in modern conditions. The author gives the definition of parallel imports, presents the chronology of legalization of parallel imports, analyzes the consequences of the introduction of the international principle of exhaustion of exclusive rights to a trademarks on the territory of Russia and the Eurasian economic union. Particular attention is paid to the problems of legalization of parallel imports, including: membership of Russia in the Eurasian economic union, insufficient validity of potential benefits and risks, as well as the inadequacy of the mechanism of protection against possible risks.

Keywords: parallel imports, intellectual property, exhaustion of exclusive rights, rightholder, trademark.

В 2012 году Федеральная антимонопольная служба Российской Федерации (далее ФАС РФ) выступила с предложением легализации параллельного импорта в России, что породило обширную дискуссию в научных кругах, среди экспертов, представителей властных структур, бизнеса.

В настоящее время изменения в законодательство не внесены, но дискуссия только продолжает разрастаться. Основным вопросом стали экономические последствия легализации параллельного импорта как для России в частности, так и для государств-членов Евразийского экономического союза (далее ЕАЭС).

Понятие параллельного импорта не закреплено ни законодательством Российской Федерации, ни ЕАЭС. Анализ работ современных отечественных исследователей и экспертов, позволяет именовать параллельным импортом ввоз оригинального брендированного (маркированного товарным знаком) товара на территорию страны неуполномоченным импортёром (лицами, не имеющими документированного согласия или санкции правообладателя на ввоз) по параллельным или альтернативным каналам, напрямую не связанным с правообладателем [1, с. 30; $2 ; 3 ; 4 ; 5]$. Таким образом, во-первых, товар является обязательно оригинальным, а не подделкой; во-вторых, на него нанесён товарный знак; в-третьих, при импорте отсутствует надлежащим образом оформленное согласие правообладателя товарного знака на ввоз товара.

\footnotetext{
${ }^{1}$ Anastasiya Salnikova, Candidate of Historical Sciences, Associate Professor, Vladimir State University named after Alexander Grigorievich and Nikolay Grigorievich Stoletovs, Russia.
} 
В мировой практике выделяют три принципа исчерпания исключительных прав на товарный знак: международный, региональный и национальный.

Международный принцип подразумевает исчерпание исключительных прав правообладателя после первого введения товара в оборот в любой стране мира. Это значит, что правообладатель, реализовав свою продукцию в любой стране мира единожды, больше не может указывать новым собственникам что делать с данным товаром далее.

Согласно региональному принципу, продажа маркированной товарным знаком продукции на территории одного государства влечёт исчерпание исключительного права на товарный знак в других.

Национальный принцип предполагает исчерпание исключительных прав правообладателя при условии первичного введения товаров в оборот на территории государства или им самим или с его разрешения. Таким образом, импорт товаров, неоднократно перепродававшихся за рубежом, возможен только с согласия правообладателя товарного знака.

В настоящее время международный принцип исчерпания исключительных прав действует, например, в Китае, Японии, Канаде, региональный - в Европейском союзе и Евразийском экономическом союзе, национальный - в Российской Федерации.

В целях защиты прав правообладателей в 2002 году в Российской Федерации международный принцип исчерпания прав на товарный знак был изменен на национальный внесением поправки в статью 23 Закона РФ от 23.09.1992 № 3520-1 «0 товарных знаках, знаках обслуживания и наименованиях мест происхождения товаров».

В 2008 году в России закреплён национальный принцип исчерпания исключительных прав на товарный знак. Статьёй 1487 Гражданского кодекса Российской Федерации было предусмотрено исчерпание исключительного права на товарный знак в отношении тех товаров, которые были введены в оборот на территории РФ непосредственно правообладателем или с его согласия (например, дистрибьюторами). Любое использование товарного знака без согласия правообладателя на территории РФ является незаконным [6, ст. 1484].

В 2010 году Соглашением о единых принципах регулирования в сфере охраны и защиты прав интеллектуальной собственности от 9 декабря 2010 года в Таможенном союзе закреплен региональный принцип исчерпания исключительных прав на товарный знак (Республикой Казахстан ратифицировано в 2012 году), который предполагает запрет на параллельный импорт товаров.

В рамках ЕАЭС также установлен региональный принцип исчерпания исключительных прав. Согласно Договора о Евразийском экономическом союзе от 29 мая 2014 года, не является нарушением исключительного права на товарный знак использование этого товарного знака в отношении товаров, которые были правомерно введены в гражданский оборот на территории любого из государств ЕАЭС непосредственно правообладате- 
лем товарного знака или лицами с его согласия [7, ст. 16]. То есть, если товары были ввезены на территорию, например, Республики Казахстан, самим правообладателем или иными лицами с его согласия, то на дальнейшую перепродажу данного товара в остальных государствах-членах ЕАЭС его согласия уже не требуется.

Таким образом, на данный момент в Российской Федерации и ЕАЭС предусмотрен запрет параллельного импорта товаров.

В 2014 году ФАС РФ был внесён на обсуждение законопроект о легализации параллельного импорта. Однако в Государственную Думу данный законопроект внесён не был в связи с отрицательным заключением Минэкономразвития РФ об оценке регулирующего воздействия [8]. В 2015 году Председателем Правительства РФ Д.А. Медведевым была одобрена сама идея легализации параллельного импорта для отдельных категорий товаров. Пилотными товарами стали (согласно ЕТН ВЭД ЕАЭС): 1) группа 30 - фармацевтическая продукция; 2) группа 87 (позиции 8703 и 8708) автомобили легковые, их части и принадлежности; 3) группа 90 (позиции 9018-9022, 9033) - инструменты и аппараты, медицинские или хирургические; их части и приндлежности; 4) позиции 7228, 8207, 8428, 8430, 8431, 8705, 8905 - оборудование, используемое при добыче трудноизвлекаемых запасов и освоении арктичских месторождений континентального шельфа; а также другие позиции ЕТН ВЭД ЕАЭС по проекту Ямал СПГ [8]. Однако, окончательный список утверждён не был и реализацию данной идеи отложили.

Необходимо отметить, что легализация параллельного импорта на территории РФ возможна только при согласовании со всеми государствамичленами ЕАЭС. В связи с этим, в конце апреля 2017 года на заседании Коллегии Евразийской экономической комиссии (далее ЕЭК) был одобрен проект Протокола о внесении изменений в Договор о Евразийском экономическом союзе от 29 мая 2014 года, согласно которому Евразийский межправительственный совет наделяется правом временно устанавливать в отношении отдельных категорий товаров действие международного принципа исчерпания исключительных прав на товарный знак. Применение международного принципа к отдельным категориям товаров возможно по инициативе государств-членов ЕАЭС в тех случаях, когда товары не доступны на внутреннем рынке ЕАЭС, имеются в недостаточном количестве и (или) продаются по завышенным ценам, а также в иных случаях, исходя из социально-экономических интересов государств-членов ЕАЭС. Для реализации данных изменений документ должен был пройти внутригосударственное согласование в каждом из государств-членов ЕАЭС до 1 июля 2017 года [9]. На сегодняшний день вопрос всё также стоит на повестке дня и его обсуждение проходит очень нелегко в связи с тем, что не все страны ЕАЭС пришли к одному решению. ФАС РФ рассчитывает, что переговоры по легализации параллельного импорта в отношении отдельных товаров на территории стран ЕАЭС завершатся до конца 2017 года. Для 
России приоритетными товарами параллельного импорта являются лекарства, медицинские изделия, автозапчасти, детские товары и некоторые другие.

В России сторонниками установления международного принципа исчерпания исключительных прав на товарный знак выступают Правительство РФ, ФАС РФ, Роспатент. Минпромторг РФ еще не сформировал свою позицию по данному вопросу. Против возможности параллельного импорта выступают представители бизнеса.

То, что на сегодняшний день не было достигнуто консенсуса по поводу легализации параллельного импорта как в России, так и в ЕАЭС, связано с неоднозначными оценками его экономических последствий. Среди преимуществ называются:

1) уменьшение случаев ценовой, качественной и ассортиментной дискриминации со стороны правообладателей в отношении российских потребителей;

2) прекращение лимитации поставок по решениям государственных органов или правообладателей;

3) снижение стоимости продукции известных марок вследствие конкуренции между официальными представителями правообладателя и независимыми импортёрами;

К негативным последствиям относят:

1)возможность снижения инвестиционной привлекательности (в первую очередь иностранных инвестиций в производство иностранных товаров на территории РФ, что повлечёт падение объёмов производства, снижение количества рабочих мест и налоговых поступлений в бюджет);

2)возможность недобросовестной конкуренции и роста количества ввозимой контрафактной продукции и, как следствие, снижение поступлений в бюджет;

3)снижение мотивации для внутреннего производства и актуальности политики импортозамещения вследствие зависимости экономики не от развития национальной промышленности, а от импорта;

4)отсутствие ответственности за низкокачественный товар, так как ввозить продукцию будут не только официальные дилеры, а любые импортёры $[1$, с. $30-35 ; 2 ; 3 ; 10 ; 11,12 ; 13 ; 14]$.

Противники легализации параллельного импорта считают, что риск потерь намного выше потенциальной выгоды.

Длительность процесса легализации параллельного импорта указывает сложность вопроса. Несмотря на это, перспектива установления международного принципа исчерпания исключительных прав на товарный знак в России и ЕАЭС вполне реальна в ближайшем будущем. В условиях неоднозначности позиций государств-членов ЕАЭС, во внутригосударственных органах каждой из стран ЕАЭС, а также в научных кругах, среди экспертов и представителей бизнеса следует более взвешенно подойти к вопросу оценки экономических последствий (численной оценки потенциальных выгод и рисков) введения параллельного импорта, а также к разработке механизма защиты от рисков его введения. 
References:

[1] Афанасьева Е.Г., Долгих М.Г. Оригинальный контрафакт, параллельный импорт и конкуренция // СПС «КонсультантПлюс» [Электронный ресурс]. - URL: www.consultantplus.ru (дата обращения: 18.10.2017).

[2] Мусаева А.М. Перспективы легализации параллельного импорта в России и ЕАЭС // Проблемы современной экономики. 2016. № 2 (58). С. 30-35.

[3] Островский И. Параллельный импорт под вопросом // СПС «КонсультантПлюс» [Электронный ресурс]. - URL: www.consultantplus.ru (дата обращения: 18.10.2017).

[4] Тюнин М.В. Параллельный импорт в Таможенном союзе // СПС «КонсультантПлюс» [Электронный ресурс]. - URL: www.consultantplus.ru (дата обращения: 18.10.2017).

[5] Фукс Е.Н. Легализация «параллельного» импорта как способ борьбы с серым импортом // Вестник Российской таможенной академии. 2017. № 3 // СПС «КонсультантПлюс» [Электронный ресурс]. - URL: www.consultantplus.ru (дата обращения: 18.10.2017).

[6] Гражданский кодекс Российской Федерации (часть 4) от 18.12.2006 (ред. от 01.07.2017) № 230-Ф3.

[7] Приложение № 26. Протокол об охране и защите прав на объекты интеллектуальной собственности к Договору о Евразийском экономическом союзе (Подписан в г. Астане 29.05.2014) (ред. от 08.05.2015) (с изм. и доп., вступ. в силу с 12.08.2017).

[8] Перспективы легализации параллельного импорта в России [Электронный pecypc]. - URL: www.fas.gov.ru (дата обращения: 21.10.2017).

[9] Межправсовет разрешит «параллельный» импорт на отдельные виды товаров в ЕАЭС [Электронный ресурс]. - URL: www.eurasiancommission.org/ru/nae/news/Pages/26-04-2017.aspx (дата обращения: 27.10.2017).

[10] Соничев А. Параллельный импорт сократит поступления в бюджет // СПС «КонсультантПлюс» [Электронный ресурс]. - URL: www.consultantplus.ru (дата обращения: 18.10.2017).

[11] Склярова Я., Шауфф Ф., Каширин М., Павлова Е., Радченко Т., Орлова В., Нестеренко А., Онищук А., Жигулин В., Юков А., Суббот А., Семенов А., Елаев А., Будылин С. Перспективы легализации параллельного импорта в России // СПС «КонсультантПлюс» [Электронный ресурс]. - URL: www.consultantplus.ru (дата обращения: 18.10.2017).

[12] Власти поддержали идею параллельного импорта товаров в рамках ЕАЭС [Электронный ресурc]. - URL: www.rbc.ru (дата обращения: 27.10.2017).

[13] Российские дилеры выступили против легализации параллельного импорта автозапчастей [Электронный ресурc]. - URL: www.rbc.ru (дата обращения: 27.10.2017).

[14] Фармацевтические компании просят Медведева не разрешать параллельный импорт [Электронный ресурс]. - URL: www.vedomosti.ru (дата обращения: 27.10.2017). 


\title{
THE PROBLEM OF INTERACTIVE VISUALIZATIONS OF DISCIPLINES FOR PRIMARY SCHOOLS
}

\author{
V. Saburov'1, A. Brezhnev²
}

\begin{abstract}
The article considers the problem of automation of teaching - learning, where part of routine tasks, previously performed by a teacher, is transmitted to automatic devices that implement the capabilities of information and communication technologies, as well as an overview of existing software packages for working with children. Due to the fact that none of these software systems do not include all necessary functionality, in this paper, we have proposed and described the concept of a new software system.
\end{abstract}

Keywords: website, teaching, learning, reading, statistics, testing, school, children, animation, rendering, report, data base, audio materials, video materials, free program, online version, an electronic version of the print edition.

Currently developed and widely used various methods of teaching for elementary schools. One of the most popular is the introduction of imaging and testing. For the study of mass educational forum "Open lesson" [7] in addition to diagnostic test functions contains educational potential.

That is why the teachers are constantly faced with the problem of editing a route, the program or book is not enough material that is very important. For example, when in the book of the world around them unavailable dismantled material such as the "ear". Then you have to either buy the program with visualized material, which is impossible to edit. This approach is inconvenient and leads to higher costs-time teachers, and funds from the school. Therefore, the problem of flow interactive visualization and editing of the route learning test is extremely important.

At the moment, there are programs that allow you to use pre-testing and prepared teaching material.

One of the most popular programs for working with the testing is "Lessons of the school curriculum" [8]. They provide material and testing, but to make their change is impossible.

There are also programs that allow you to view and select test. One of them is "Elementary school. Lessons Cyril and Methodius" [9]. This program provides rich animation and allows you to choose the test after studying the material, but to make their change is impossible.

1Vladislav Saburov, Russian Federation, Kursk, of the "Southwestern state University", Russia.

2Alexey Brezhnev, FGBOU VPO "Russian economic University named after Plekhanov", Russia. 
It should be noted that not all existing programs have a web version. This leads to the inconvenience of downloading and installing the product on a personal computer before its use.

Another disadvantage of the above programs for a training route with testing is the fact that they allow you to select test from the list that are inherent in the program. In this regard, the teacher has no opportunity to edit the test for route learning.

In the substituted table 1 comparative characteristics of two existing programs, described above, and the created software.

Table 1

Comparative analysis of existing programs and created a software product

\begin{tabular}{|l|c|c|c|}
\hline \multicolumn{1}{|c|}{ THE NAME OF THE FUNCTIONS } & $\begin{array}{c}\text { "Lessons of } \\
\text { Cyril and } \\
\text { Methodius" }\end{array}$ & $\begin{array}{c}\text { "Lessons of } \\
\text { the school cur- } \\
\text { riculum" }\end{array}$ & $\begin{array}{c}\text { This } \\
\text { product }\end{array}$ \\
\hline The web version of the book & $\checkmark$ & $\checkmark$ & $\checkmark$ \\
\hline Analytical testing & $\checkmark$ & $\times$ & $\checkmark$ \\
\hline Automated stats & $\times$ & $\times$ & $\checkmark$ \\
\hline Animated images & $\times$ & $\times$ & $\checkmark$ \\
\hline Statistics in the form of reports & $\times$ & $\times$ & $\checkmark$ \\
\hline Options with text & $\times$ & $\times$ & $\checkmark$ \\
\hline Electronic version of the book & $\times$ & $\times$ & $\checkmark$ \\
\hline Content creation & $\times$ & $\checkmark$ & $\checkmark$ \\
\hline Content editing & $\times$ & $\checkmark$ & $\checkmark$ \\
\hline Free use & $\times$ & $\times$ \\
\hline Audio & $\times$ & $\times$ & $\checkmark$ \\
\hline Videos & $\times$ & $\times$ & $\checkmark$ \\
\hline
\end{tabular}

In this regard, it is feasible to create a software product that would integrate all the functions on the edit test and change the inner content. The created product is presented as a web application that will allow users to access it using the Internet without installing extra software on your computer.

Developed a software product will find wide application, for example, when used in secondary schools who are actively using interactive visualization to quickly change the visualization and editing of route learning testing them. 
The main objectives during the development of this software product are:

- create a database directory materials with the possibility of adding new materials to the system;

- create web interface to database and to edit the materials and their conservation;

- implementation of an algorithm for interactive visualization the display of the pedagogic material;

- creating web interface to work with the teaching material, as well as editing it and saving;

- create test suites to verify the correctness of the program.

It can be concluded that the software developed meets the user requirements. Rather than changing the test and teaching material manually or use multiple programs when you can use one created by the program with which the user is able to view the web tutorials, create, edit and save the edited material into the computer.

This software product can be used in various educational institutions using interactive whiteboards or projectors. Thus, the effect of the use of the program is a quick creation and editing, instant change of its content. This fact confirms the possible future use of the developed software product to address the problem of interactive visualizations of disciplines from editing to testing to the route of study.

\section{References:}

[1] Tomakova, R. A. Fuzzy model of morphological operator for the formation of borders of the segments/ Tomakova R. A., Filist S. A., Rudenko, V. V.// Bulletin of Belgorod state University. Series: Economics. Informatics. 2011. T. 17. 31-1(96). -P. 188-195.

[2] Dudin, M. V. Methods and algorithms of contour analysis for classification tasks konstruktoriu images/M. V. Dudin, A. D. Povalyaev, E. S. Basement, Tomkova R. A.// Bulletin of Voronezh University. 2014. T. 10. No. 3-1. -P. 54-59.

[3] Tomakova, R. A. konstruktoriu Method of processing images based on built-in functions of MATLAB/Tomakova R. A., Filist S. A.//Vestnik of the Transbaikal state University. 2012. No. 1. -P. 3-9.

[4] Tomakova, R. A. Comparative analysis of the efficiency of the method of segmentation of gray-scale raster image based on the selection of the priority directions of the treatment of the boundaries of the segments/ Tomakova R. A., Filist S. A., Komkov S. V., Sorokin, S. A. //Problems of Radioelectronics.2015. No. 9. -P. 133-151.

[5] Saburov, V. G. an application for interactive visualization disciplines for primary school, implemented on the example of the subject "Surrounding World" / V. G. Saburov, O. M. Malkov, A. A. Rodin.: The collection of materials of all-Russian conference "the Program is interactive visualization disciplines for primary school, implemented on the example of the subject "Surrounding World"'. -2017. S. items 148 to 159.

[6] Saburov, V. G. Integration of multimedia educational program in the process of ecological education of younger schoolboys //G. V. Saburov, O. M. Malkov, R. A. Tomakova.: Collection of articles IX International scientific-practical conference "Integration of multimedia educational program in the process of ecological education of younger schoolboys". -2017. -Pp. 338-342. 
[7] Testirovanie as one of the most effective forms of control [Electronic resource]// the mass of The open pedagogical forum "Open lesson" (C) ID "First of September". URL: http://festival.1september.ru/articles/414757. (10.12.2016)

[8] Videouroki school curriculum, notes, tests, and simulators [Electronic resource]// the mass of The open pedagogical forum "Open lesson", (c) 2010-2017 Interda, 000. URL: https://interneturok.ru. (Accessed 11.12.2016)

[9] Uchebno-methodical set of "Elementary school. Lessons Cyril and Methodius" [Electronic resource]// "Elementary school. Lessons Cyril and Methodius", (C) "Cyril and Methodius". URL: http://nachalka.info. (Accessed 12.12.2016) 


\title{
APPROACHES FOR RISK ANALYSIS OF THE ORGANIZATION ACCORDING TO ISO 9001:2015
}

\author{
S. Kreneva ${ }^{1}$, G. Tsareva², Ya. Yurchenko ${ }^{3}$
}

\begin{abstract}
The paper considers the main approaches to the organization's risk analysis in accordance with ISO 9001: 2005. The stages of management of any risks are identified: identification and analysis of risks, analysis of alternative methods of risk management, selection of methods for managing rice, implementation of the chosen risk management method, monitoring of results. The method of hazard analysis and critical control points is considered, its advantages and results are revealed after implementation of this method in the organization's activities. Identified the main stages in the event to manage significant and critical risks. Three main groups of methods for influencing risk are identified: risk reduction, risk preservation, risk transfer. Using the proposed risk analysis methodology will improve the performance indicators of processes in any organization.
\end{abstract}

Keywords: analysis, methodology, risks, standard ISO 9001: 2015.

\section{Introduction}

Diagnosing risks is just as necessary for their prevention as the diagnosis of a disease is necessary for its treatment.

Risk management is one of the most promising and dynamically developing areas in the field of organizational quality management technologies. The main goal of risk management is to identify, reduce and prevent errors and adverse events, for which a number of tasks are being solved, among which the analysis of risks and threats existing at the level of individual organizations and at the level of national systems is not the last place.

In most of the world's economically developed countries, significant attention is paid to risk management. In many countries, there are a number of organizations whose purpose is to maintain and improve the monitoring system for adverse events, to disseminate experience, and to issue and revise methodological recommendations. To control the quality of service, most organizations rely on ISO standards (ISO 9001: 2015, ISO31000: 2009) in their activities.

\section{Methods and results}

To determine priority objectives, identify the most acute problems, monitor changes and evaluate the effectiveness of measures, it is necessary to use tech-

\footnotetext{
${ }^{1}$ Svetlana Kreneva, Associate Professor, Mari state university, Russia.

${ }^{2}$ Guzal Tsareva, Associate Professor, Volga State University of Technology, Russia. ${ }^{3}$ Yana Yurchenko, Graduate student, Mari state university, Russia.
} 
niques that have the ability to measure certain characteristics of errors and undesirable events, and to ensure the stability of the results obtained for the purpose of their periodic comparison.

According to existing risk management techniques, the sequence of actions for managing any risks can be divided into stages:

- Identification and analysis of risks.

Analysis of causes is a method by which you can identify the main causes of incidents and risk situations. There are various methodologies for carrying out this method, but all of them are aimed at revealing: "what happened", "how it happened", "why did it happen?" Search and identification of risks can be carried out in various ways. This can be done through internal audits of the departments and the organization as a whole. With the help of surveys and questionnaires you can get information from the client. Part of the information on possible threats can be obtained from the guidelines and various scientific papers. Sources of risk identification can be staff who reported the incident on time.

- Analysis of alternative methods of risk management.

The main goal of this stage is to study the tools with which to minimize the consequences of the impact of risk (an analysis of what we need to do so that this situation does not happen again). For example: consideration of the increase in staff, the creation of training programs for staff and so on.

- Selection of risk management methods.

This stage is designed to form an organization's policy in the field of combating risk and uncertainty (choosing effective measures to prevent situations that entail a breach of the client's security).

- Execution of the selected risk management method.

This stage involves the adoption and implementation of selected solutions. At this stage, the deadlines for the implementation of activities are determined, as well as the resources needed to implement these activities.

- Monitoring of results.

At this stage, the effectiveness of the selected method is evaluated and the possibility of using it in the future is confirmed.

All of the above steps help determine the significance of various aspects that pose a threat to the patient, which makes it necessary to implement a risk management system in the organization. Analysis of the causes and factors contributing to the emergence of risks, the development of measures to minimize their effects are engaged in risk management professionals - risk managers.

Standard ISO 9001: 2015 does not establish methods for risk assessment, that is, the organization itself has the right to choose or develop a new methodology for risk assessment.

The method of hazard analysis and critical control points is more applicable in the organization than other risk assessment techniques reflected in GOST $\mathrm{R}$ ISO / IEC 31010-2011 "Risk Management. Methods of risk assessment.

This method allows you to build a structure for identifying hazards and checking controls in all parts of the process. This method is aimed at protecting from hazards and ensuring high reliability and security of the provided service. 
The main purpose of the method is to minimize the risk by applying management tools in the process of providing the service.

The advantages of the method:

-is a structured process that provides documented evidence of the quality of hazard identification, management and risk reduction;

-is focused on solving practical questions: how and where in the process can prevent the emergence of hazards and manage risks;

-allows you to manage the risk in the process of providing the service, not relying solely on control "on the way out";

-provides an opportunity to identify the dangers caused by human actions, and contains a method of control at the time of the commission of an erroneous action or subsequently.

This method is described in more detail in GOST R 51705.1-2001 "Quality systems. Food quality management based on HACCP principles. General requirements". Taking as a basis the requirements of this GOST and GOST R ISO / IEC 31010-2011, this methodology was adapted for the organization.

According to this methodology, the organization:

1. Identifies potential hazards that may arise in the process of providing services.

2. For each process, according to the approved list, a matrix of hazards is compiled.

When analyzing the existence of risks at each stage, it is necessary to adhere to the algorithm for determining risk. The basis of this algorithm is the "Decision tree" for determining critical control points used by food enterprises.

Risks are determined by analyzing separately for each considered potential hazard and consistently considering all operations included in the process algorithm.

A prerequisite for risk management is the presence of risk signs (the identification of potential hazards and (or) preventive (controlling) impacts that eliminate risk or reduce it to an acceptable level at the stage under review.

3 . The analysis of risk factors affecting the activities of the organization is carried out.

With the expert method, taking into account all available information and practical experience of personnel, each potential danger threatening the client at this stage of the process is evaluated taking into account the "probability of occurrence" and the "severity of consequences" from its impact.

The probability of occurrence from the realization of the danger is estimated based on 3 possible variants of the assessment:

\begin{tabular}{|c|c|}
\hline Notation & The likelihood of a hazard (BB) \\
\hline 1 & $\begin{array}{c}\text { Low level } \\
\text { (the probability is zero) }\end{array}$ \\
\hline 2 & $\begin{array}{c}\text { Average level } \\
\text { (probability is possible) }\end{array}$ \\
\hline 3 & $\begin{array}{c}\text { High level } \\
\text { (the probability is high) }\end{array}$ \\
\hline
\end{tabular}


4. Risk analysis maps.

The results of the assessment of the "likelihood of occurrence" and "severity of consequences" are summarized and recorded in the form of a "Risk Analysis Card".

The severity of the consequences from the realization of the hazard is assessed based on three possible assessment options:

\begin{tabular}{|c|c|}
\hline Notation & Severity consequences (Tp) \\
\hline 1 & A minor threat to the deterioration of human health \\
\hline 2 & $\begin{array}{c}\text { Moderate Gravity } \\
\text { (minor damage to human health) }\end{array}$ \\
\hline 3 & $\begin{array}{c}\text { Severe consequences } \\
\text { (serious damage to human health until death) }\end{array}$ \\
\hline
\end{tabular}

The results of the "probability of occurrence" and "severity of consequences" evaluation are summarized and recorded in column 5 of the Risk Analysis Card.

Based on the results obtained, the boundary of the permissible risk is determined using a matrix with coordinates: "probability of occurrence" and "severity of consequences".

Classification of hazards:

5-6 significant (unacceptable)

4 medium

2-3 minor (acceptable).

Form of Risk Analysis Card

\begin{tabular}{|c|c|c|c|c|c|c|c|c|c|}
\hline \multirow[b]{2}{*}{$\begin{array}{c}\text { Pro- } \\
\text { cess } \\
\text { step / } \\
\text { proce- } \\
\text { dure } \\
\text { item }\end{array}$} & \multicolumn{4}{|c|}{ Description of risk } & \multirow[b]{2}{*}{$\begin{array}{l}\text { Conse- } \\
\text { quence } \\
\text { of risk }\end{array}$} & \multirow[b]{2}{*}{$\begin{array}{c}\text { Risk } \\
\text { Status }\end{array}$} & \multirow[b]{2}{*}{$\begin{array}{c}\text { Causes of } \\
\text { risk } \\
\text { (factors af- } \\
\text { fecting } \\
\text { risk educa- } \\
\text { tion) }\end{array}$} & \multirow[b]{2}{*}{$\begin{array}{c}\text { Risk } \\
\text { man- } \\
\text { age- } \\
\text { ment } \\
\text { activi- } \\
\text { ties }\end{array}$} & \multirow[b]{2}{*}{$\begin{array}{c}\text { Respon- } \\
\text { sible for } \\
\text { imple- } \\
\text { menta- } \\
\text { tion of } \\
\text { risk } \\
\text { man- } \\
\text { age- } \\
\text { ment } \\
\text { activi- } \\
\text { ties }\end{array}$} \\
\hline & $\begin{array}{c}\text { Risk } \\
\text { de- } \\
\text { scrip- } \\
\text { tion }\end{array}$ & $\begin{array}{c}\text { Proba- } \\
\text { bility of } \\
\text { dangerв } \\
\text { (Bв) }\end{array}$ & $\begin{array}{l}\text { The se- } \\
\text { verity } \\
\text { of the } \\
\text { conse- } \\
\text { quences } \\
\text { (Tp) }\end{array}$ & $\begin{array}{c}\text { De- } \\
\text { gree } \\
\text { of } \\
\text { risk }\end{array}$ & & & & & \\
\hline 1 & 2 & 3 & 4 & 5 & 6 & 7 & 8 & 9 & 10 \\
\hline 1 & & & & & & & & & \\
\hline
\end{tabular}

Risk is the last point of control during the process, where danger can be eliminated. The control points can be set, and there are only a few risk points, otherwise the process will be unmanageable. Critical limits are set to ensure an acceptable identified level of hazard. Critical limits must be measurable. 
Critical limits, the determination of which is based on subjective assessment (for example, through visual inspection of products, processes, handling of products, etc.), instructions and / or personnel with appropriate education and training should be developed for their application.

Activities to manage significant and critical risks include the following main stages:

- Identification of risk alternatives, admitting it only within a socially, economically and morally acceptable level;

- Development of specific recommendations aimed at eliminating or minimizing the possible negative consequences of risk;

- Creation of special plans that allow to optimally act in a critical situation to people who implement decisions at risk or control this process;

- Preparation and adoption of normative acts that help to implement the chosen alternative;

- Taking into account the psychological and moral perception of risky decisions and programs, etc.

Among the methods of influencing risk, there are three main groups:

- Risk reduction implies a reduction in either the amount of possible damage or the likelihood of adverse events. Most often, it is achieved through the implementation of preventive organizational and technical measures, which are understood as different ways to strengthen the security system (training of personnel, the introduction of systems adequate to the tasks of training, etc.);

- Maintaining risk does not always mean giving up any action. The organization can create a reserve fund, self-insurance funds or risk funds, from which compensation will be made for losses in the event of adverse situations. This method of risk management is called self-insurance;

- Risk transfer means transfer of responsibility for it to third parties while maintaining the existing level of risk. These include insurance, as well as various types of financial guarantees, sureties, etc.

\section{Conclusion}

Ultimately, we can conclude that the use of risk analysis has the following effect: constant monitoring at the stages most likely to entail responsibility, including adverse outcomes and incidents; strengthened control over "weak" places; increase customer satisfaction; reduction in cases of rendering services of inadequate quality; decrease in the number of customer complaints.

Using the proposed risk analysis methodology will improve the performance indicators of processes in any organization.

The advantages of the method:

-It is a structured process that provides documented evidence of the quality of hazard identification, management and risk reduction;

-It is focused on solving practical questions: how and where in the process can prevent the emergence of hazards and manage risk;

-It allows you to manage the risk in the process of providing the service, not relying solely on the "exit" control; 
-It makes it possible to identify the dangers caused by human actions, and contains a method of control at the time of the commission of the erroneous action or subsequently.

Thus, the introduction of the risk analysis methodology in the organization will allow for constant monitoring of the "weak spots", which will entail an improvement in the qualitative and quantitative performance of the organization itself.

\section{References}

[1] ISO9001: 2015 (2015). Quality management systems, 32.

[2] ISO 9000: 2015 (2015). Quality management systems. Basic provisions and vocabulary, 59.

[3] GOST R ISO 31000-2010. (2012). Management of risks. Principles and recommendations, 24.

[4] GOST R ISO / IEC 31010-2011. (2012). Management of risks. Methods of evaluation, 74.

[5] GOST R ISO 9004-2010. (2011). A guide for achieving a sustainable organization success. An approach based on quality management, 57.

[6] Halturina Elena N., Kreneva Svetlana G., Tsareva Guzal R., Yelagina Vilena B., Tereshina Vlada V. (2017) Features definitions of performance management system implementation of the quality and safety of food products to the enterprise . INTCESS 2017- 4th International Conference on Education and Social Sciences held during 6-8 February, 2017 in Istanbul, TURKEY. - P.758-766. 1

[7] Kreneva Svetlana G., Tereshina Vlada, Halturina Elena N., Larionova Tamara P., Shvetsov Mikhail N. (2015). Influence of factors of production on efficiency of production systems. Mediterranean Journal of Social Sciences, Vol 6, No 3 S7 411pages.

[8] Baldin, KV (2012). Risk management, 512.

[9] Kudryavtsev N.S. (2016). Introduction to Quantitative Risk Management, 192.

[10] Makolov V.I. (2015). Problems of quality management systems of Russian organizations in modern conditions, 214.

[11] Mikheeva, E.N. (2017). Quality management, 531.

[12] Nikolaev, MI (2016). Metrology, standardization, certification and quality management, 116.

[13] Norenko, Yu.I. (2012). Ways to increase the competitiveness of enterprises based on the use of modern quality management technologies, 108.

[14] Fomichev, A.N. (2016). Risk management, 372.

[15] Chekaldin, A.M. (2015). Process approach to quality management in enterprises, 54.

[16] Shibaev, M.A (2012). International quality standards, 95. 


\title{
MEDICAL TOURISM RESOURCES IN KAKHETI ON THE EXAMPLE OF AKHTALA
}

\author{
G. Mamulashvili' ${ }^{1}$ T. Tamarashvili ${ }^{2}$
}

\begin{abstract}
In the following article the importance of medical tourism is viewed.The charesteristics of resorts in Kakheti.Vital abilities for medical tourism development is separately presented as well, featured peloid resort Akhtala with peculiarities and developing stages.In the article the historical background of resort and current condition is viewed.Research is based on archive documents, periodic press and modern scientific literature.The article has conclusions where the perspectives and future developing ways of resort is presented with a view of medical tourism.
\end{abstract}

Keywords: Peloid resort, recreational tourism, perspectives, akhtala, kakheti.

Введение. Медицинский туризм - термин, обозначающий практику предоставления медицинских услуг за пределами региона проживания, совмещение отдыха за рубежом с получением высококвалифицированной медицинской помощи. Медицинский туризм сравнительно новый термин, хотя история лечебного туризма насчитывает тысячелетия, так как люди с древнейших времён путешествовали для получения медицинского обслуживания. «Медицинский туризм и оздоровительный туризм часто употребляются как синонимы. Хотя между ними есть существенная разница. Медицинский туризм - получение обслуживания за пределами страны или в стране, в нём слиты отдых за границей вместе с высококвалифицированным медицинским обслуживанием, а оздоровительный туризм является реабилитацией для остановления уже существующей болезни или для восстановления здоровья». [Л. Корганашвили «Международный туризм», стр. 200, 2012 г., Тбилиси] [1.200]

Методы исследования: В статье использованы следующие методы: 1) метод анализа и синтеза, последовательное описание и объективный анализ фактического материала; 2) метод системности; 3) метод стуктурного анализа.С куждым днём растёт потребность в медицинском туризме. В настоящее время множество курортов мира специализирована на лечении того или иного заболевания.

Грузия- страна, которая выделяется на всём Кавказе богатыми туристическими и рекреационными ресурсами. Для визитёров весьма важным является её природа, полная контрастов (Кавказ, Чёрное море, озёра, реки, минеральные воды, леса, водопады, пещеры), исторические и культурные

\footnotetext{
${ }^{1}$ Gela Mamulashvili, student, International Black Sea University, Georgia.

2Tamar Tamarashvili, associated professor, Iakob Gogebashvili Telavi State University, Georgia.
} 
достопримечательности, которые используются местными или приезжими визитёрами для отдыха, развлечения или лечения. Увидеть Грузию желали многие люди, причинами их интереса были военная дорога, столица, которая была прославлена серными банями, побережье Чёрного моря и т.д.

На сегодняшний день правительство признало туризм приоритетной отраслью и здесь активно развиваются многие направления туризма, чему способствуют туристический и рекреационный потенциалы, в стране может быть развит горнолыжный, культурный, познавательный, ремесленный, археологический, экологический, религиозный, винный и медицинский туризмы. Нужно отметить, что с точки зрения лечебно-оздоровительного туризма Кахетинский регион весьма интересен и он обладает многосторонними ресурсами.

Кахетия характеризуетсямногообразием природных условий, притягательностью и красотой. С туристической точки зрения это один из перспективных регионов Грузии, что определено выгодными природно-экономическими факторами.

Кахетинский регион «находится в восточной части Грузии и по площади она среди историко-географических провинций занимает второе место. В неё входят бассейны реки Алазани, а также среднее и нижнее течения реки Иври.» [2. Н. Иза Чинчарашвили, Климатический ресурс Кахетинского региона, стр. 6, Тбилиси, 2009]. [2. стр. 6]

Кахетия одна из красивейших частей Грузии, обладающая огромным выбором туристических ресурсов для планирования экологических, религиозных, культурно-познавательных туров. Нужно иметь в виду, что в настоящее время в Кахетии функционирует множество курортов, что региону даёт возможность развития медицинских туров, кроме того здесь имеются климатические и бальнеологические курорты, но весьма интересным является курорт пелоидного типа.

«1. Курортами климатического вида являются курорты, которые характерны здоровым климатом и лечебными свойствами; 2. Основным лечебным фактором бальнеологических курортов являются минеральные воды; 3. Курорты лечебной (пелоидной) грязи, возникают у месторождения географически лечебной грязи. (Иногда грязевый курорт рассматривают в составе бальнеологических курортов)». [Хомерик Г., Туризм, Тбилиси, 2008, 2008, стр. 65, 66] [3.65]

Из курортов, существующих в Кахетии интересны:

1. Архилоскало (в Дедоплисцкаройском муниципалитете) - характерен прекрасным климатом, «используется при нефритах и пиелонефритах, для лечения цистита» [4] http://travelingeorgia.ge/region/Resort-Arkhiloskalo/

2. Лагодехи (в составе Лагодехского муниципалитета) «бальнеологический курорт, низкий горный климат и слабо-сульфидные и натриевые минеральные воды ссеро-водородным составом. Среди типов лечения ванны из минеральной воды, пассивная климатотерапия, используются при лечении заболеваний костно-суставной системы». [5]http://travelingeorgia.ge/region/Resort-Lagodekhi/ 
3. Бальнеологический курорт Уджармы (в составе Сагареджойского муниципалитета). Здесь у визитёров имеется возможность провести «Бальнео-терапевтическое лечение, физиотерапию и реабилитацию, оздоровительные процедуры.

4. «Циви Кода» (в составе Сагареджойского муниципалитета) характерен хвойным лесом (кавказской елью, пихтой), вид лечения -пассивная климатотерапия. Используют при лечениидыхательных путей.

5. В Тетрицкаройском районе также функцинирует бальнеологичесий курорт;

6. Горным рельефом выделяется «Торгвас Абано» (в составе Телавского муниципалитета), он находится на склоне Кавказа, используется при лечении опорно-двигательного аппарата и периферийной нервной системы.»[Журнал «Перспективы и мировой опыт развития туризма», Тбилиси, 2016, стр. 54][6.54]

7. Бальнеологический курорт Кварели (в составе Кварельского муниципалитета) обладает миеральными водами двух типов, используется для лечебных ванн.

Среди выше перечисленных курортов, выделяется Ахтала. Пелоидотерапия является активным методом курортой медицины. Грязевая процедура действует на организм человека путём химического, теплового, механического и электронного раздражения рецепторов, находящихся в кожном покрове человека. При процедуре кожа впитывает газы, которые находятся в составе грязи, они же в свою очередь оказывают лечебное действие на организм человека. Также присходит впитывание биологически активныхи радиоктивных веществ, эстрогенных соединений. Некоторые бактериофаги, обнаруженые в грязевой массе, борятся с инфекцией, при гелоидотерапии расширяются кровеносные сосуды, учащается пульс, дыхание. Апликация имеет эффект схожий с массажем, что помогает активизации капиляров и укреплению сердечно-сосудистой системы. [Журнал «Аверси», 2014, № (108)] [7.52-53]

«Ахтала - грязевой лечебный курорт в г. Гуджаани, который находится в 122 км. от Тбилиси и на 412 м. от уровня моря, здесь умеренный континентный климат. Лечебный фактор курорта псевдовулканическая грязь, которую используют для ванн, аппликаций и тампонов. На Ахтале 2 санатория - 1 для взрослых и 1 для детей, поликлиника. Показателями для ванн являются: хронические заболевания органов движения, а также заболевания периферийной нервной системы и гинекологические заболевания». [Грузинская Советская Энцикопедия, т. 2, стр. 109, Тилиси, 1977 г.] [8. 109]

Грязевой вулкан Кахетии - Ахтала характерен жидкой грязью, которая сопутствуется газом, минеральными водами и песком. Из нескольких кратеров течёт жидкая грязь с нефтевой водой, газом и минеральной водой. Химический анализ данного состава показал, что грязь содержит, бром, барий, высокоминеральную воду хлористого натрия. Суточный объём нефтевого газа составляет 700 кубических метров. 
Профессор Одесского университета Пётр Меликишвили ещё в 1896 году изучил химические свойства Ахталы, а результаты исследоваия опубликовал на русском и немецком языках. В восточной Грузии известны и изучены несколько подобых вулканов, к ним относятся: Ахтала, Пховели, Западный Кила-Купра, Цетральный Кила-Купра, Баида, северный ТиулкиТапа и южный Тиулки-Тапа, они расположены на территориях Гурджаани, Сагареджо, Сигнаги и Дедоплисцкаро. Массу изверженной из земли грязи используют в лечебных целях, а нефть используется в виде топлива.» [Книга «Наши достояния», стр. 214, т. 5, Тбилиси, 2014 г.] [9. 214]

Относительно грязи Ахталы и её лечебного значения весьма интересными являются материалы 20-тых годов XX века. В своей монографии врач Д. Джавахишвили рассказывает о своеобразиях лечения грязью.

«Лечение грязью так же старо, как и сама медицина. Для лечения разных болезней лечение грязью и песком использовали египтяне (использовали грязь и песок Нила). В таких странах как Франция, Германия и Россия, имеются материалы о пользе подобного лечения ещё со средних веков, а в Грузии центром подобного лечения является Ахтала. Само слово происходит с татарских слов «аг» - белый и «тала» - поле. Т.е. имеется в виду светло серый цвет, именно этот цвет доминирует на всей территории Ахталы. Но нужно отметить, что есть ещё и второе название «Ведза», что обозначает солёную воду, а грязь действительно имеет солёный вкус.

Опользе Ахталы пишут Платон Иоселиани в своём труде «Путешествие по Кахетии», врач Сигнагского уезда Алексей Месхишвили и аптекарь из Тбилиси Шмидт (изучивший состав грязи).

Под руководством врача-ординатора Тукурмишского военного госпиталя Некрасова на территории Ахталы было открыто отделение летнего госпиталя. Что же касается внешнего вида самой грязи, то она серая, а поверхность покрывается тонким оранжевым масловидным пенистым слоем. С середины грязевого бассейна непрерывно, булькаясь, выходит грязь с характерным запахом. Бассейн изменчив, бульканье иногда будто замедляется, а потом вновь просыпается, начиная клокотать и бурлить с удвоенной силой. Температура составляет 17-18 градусов. Местные люди пользовались Ахтальской грязью, купаясь в самом бассейне, кроме того её разогревали в кастрюлях, так что в начале века лечение носило примитивный характер, были построены бараки и лишь дощатые комнаты. В одной такой комнате размещалась администрация, в другой кухня и столовая, а остальные были для больных. Сама методика получения ванн была весьма примитивной, и всё было бедно обустроено. Грязь оказывала действие на кровеносные сосуды, обмен веществ в организме и на общее состояние человека, лечились от хронических воспалений, бронхиальной астмы, гинекологических и ревматических заболеваний, эффективно лечили невралгию, невриты, раненных воинов.

«В 1922 году на Ахтале лечились 484 человека, среди них были больные с ревматизмами, неврастенией, заболеваниями периферийной нервной системы, кожи, лимфатических узлов. Из 484 человек полностью излечились 
63 человека. Этой грязью лечились и в Тбилиси, вывозя её в отдельной посуде, лечить можно было амбулаторно, а также и в домашних условиях.» [Д. Джавахишвили, Ахтальская грязь и её значение, Тбилиси, 1925 г.] [10]

0 данном курорте весьма интересные материалы содержит и периодическая пресса Грузии начала XX века.

«Газета «Путушественник» публикует статью об Ахтале, в которой говорится следующее: «Читатель, представь себе место в 100гумен, глубокое, на дне, приблизительно в 13-14 местах, булькаясь, выходит нефть, вода и грязь - это и является Ахталой. По легенде здесь когда-то была деревня, но после обмолота в день Яблочного Спаса бог разгневался на людей и всю деревню поглотила пропасть. «Ахтала» лечебная грязь, образующаяся в тех местах, где в недрах земли находятся нефть и различные газы. Вода, нефть и газы в глубине земли растапливают глину и землю и она вытекает наружу, приобретая подобный вид. Именно таким является грязь Кахетинской Ахталы». [Журнал Путешественник, Гиоргобистве №11, 1901 г.] [11, стр. 2]

В периодической прессе постоянно публиковалась информация, которая давала курортам медицинскую характеристику. В 1919 году газета «Доктор» №5-6, стр. 88-86 сообщала, что «Ахтала находится в Кизики, с. Гурджаани, в 119 верстах от Тбилиси. Местным земством уже построено четыре палатки из досок. Первым человеком, который решил изучить данную грязь с научной точки зрения, был Сигнагский земский доктор Ал. Месхишвили, после него доктор Лисицев прислал несколько больных, заставил их принять ванны, результатом остался доволен. С 1850 года аптекарь Шмидт изучил состав грязи, а 1863 году здесь был построен военный госпиталь. Всё это явствовало о лечебных свойствах Ахталы. В описании Карповича от 1868 года мы читаем: «изученный мною вулкан, занимает 56 десятин земли, здесь нет растительности, земля покрытазолой. Наблюдаютсяместа от потухших вулканов, из которых время от времени виходят газь и грязь. Недалеко от грязи есть и источник минеральной воды со вкусом серы, которую используют для лечения от желудочно-кишечных заболеваний. Больные в основном купаются в бассейнах, а некоторые греют воду в больших кастрюлах и купаются в них. Бассейны имеют разные размеры, некоторые в 3 сажени, а некоторые совсем маленькие». Многие люди вылечились благодаря этой грязи, а многим стало намного лучше.

Автор статьи с сожалением говорит о плохих условиях и грязной среде. «В одном бассейне купаются больные, а в другом - буйволы». [Журнал «Доктор», № 5-6, стр. 55-86] [12. 88 - 86]

Как видно из материалов, на Ахтале были серьёзные проблемы, не было достаточного количества ванн, продуктов, отсутствовали соответствующие санитарные условия, здесь же говорится и о малярии, которая была распространена в этом районе.

«... из Тбилиси нужно перевезти 20 больных и разместить их в палатках полевого типа, им нужны кровати, посуда, лекарства. Врачи должны осуществлять бальнеологические наблюдения, изучать действие грязевых 
ванн на организм человека. Доктора пожелали, в дальнейшем построить здесь бальнеологический курорт» - писала газета «Доктор». [Там же]

О значении и курортном потенциале Ахталы можно найти почти идентичную информацию в газете «Всадник» от 24 октября 1920 года.

Здесь указано, что лечились приблизительно 200 человек, среди них много было довольных и выздоровленых людей. Как видно из материалов «больные помещались в палатку, вместимостью в 100 человек, что в дождливую погодубыло весьма неудобным. Их обслуживали очень примитивно, разогревали грязь в кастрюлях, разбавляли холодной грязью и таким образом проводили процедуры. В жару подобные процедуры были удобными и даже приятными, но при дожде и ветре эта процедура вполне могла стать роковой. Кроме всего прочего было очень тесно, грязно,отсутствовали места для снятия одежды. Всё это пациентам создавало определённые трудности.» [Газета «Всадник», 1920 г. 24 октября] [12]

В фондах национального архива Грузии была обнаружена документация, которая ясно показывает какая работа велась на Ахтале. В начала прошлого века «согласно приказа правительства от 1919 годадля больных офицеров и военных нужно было:

«обустроить санитарную станцию с 20 кроватями и 5 кроватей для офицеров. При необходимости расширить станцию до 50 кроватей. Военному отделу даётся право назначить медицинский персонал на санитарную станцию и передать ей бочки вместимостью в 40 вёдер, а для снабжения водой - лошадь, два медные или цинковые кастрюли для подогрева воды.» [Архив, фонд 2003, опись 1, дело 7] [13]

При лечении грязью результат был настолько эффективным, что решили «на Ахтале построить лечебную поликлинику на 100 кроватей, которая в дальнейшем была переделана в санаторий, а после было построено капитальное здание для лечения грязью. Ахтальская лечебная грязь даёт эффективный результат при заболеваниях периферийной нервной системы, ревматических болезнях и др.» [14] [Рекреционные районы Грузии, вспомогательный учебник для студентов, изучающих туризм. Тбилиси, 2005 г., стр. 122]

В середине XX века «по приказу курортного управления уже осуществляли повышение специализации медицинского персонала. К Ахтале институтом курортологии Грузии был прикреплён постоянный консультант - кандидат медицинских наук М. Меликишвили, который на протяжении всего курортного сезона должен был осуществлять систематическое и научное руководство, для медицинского персонала проводились семинары и регулярные лекции. Институтом курортологии для улучшения диагностики и лечения была разработана специальная методика, систематически проводились конференции научно-практического характера.» [15] [Отдел новой и новейшей истории, фонд 1633, опись 4, дело 148, л. 5] Как видно из материалов, к 60 годам XX века значительным образом была изменена материально-техническая база курорта. «В 1962 году на Ахтале для подростков, на 100 кроватейдействовал санаторий «Алазани», и детский 
санаторий на 65кроватей, была поликлиника с 8 лечебными и диагностическими кабинетами. В санаториях лечение проходили пациенты с заболеваниями опорно-двигательной системы, гинекологическими заболеваниями т.д. Врачи санатория регулярно проходили курсы повышения квалификации: «4 врача и 5 медицинских сестёр прошли квалификационные курсы в Ленинградском институтеусовершенствования врачей, курорт был оснащён диагностическими кабинетами». [Фонд 1633, дело 280, стр. 1] [16]

«В архиве сохранились результаты лечения больных в зависимости от их заболеваний. В списке можно найти списки болезней многих видов - полиартриты разной степени, радикулиты, гинекологические и кожные заболевания. Делали грязевые апликации, массажи, утром делали лечебнооздоровительные упражнения, пациентам проводили лабораторные исследования. Из данных материалов можно понять, что правительство заботилось об этом курорте и благоустройстве санатория, было посажено 1500 деревьев и зелёных саженцев, санаторий был обеспечен внешним освещением, хлорированной водой, для врачей и медицинских сестёр здесь постоянно проводились лекции и семинары. Кроме больных санатория на Ахтале лечение проводили и амбулаторным пациентам, которые пользовались городской гостиницей и частными домами населения. На курорте для пациентов функционировали терапевтическая, гинекологическая, физиотерапевтические кабинеты, кроме того был также кабинет клинико-диагностической лаборатории.» [там же стр. 17]

В архивной документации можно встретить и формы реклам того периода: «Сразу же во время начала сезона был сделан фильм - журнал и телевизия также соответствующим образом показали значение и достоинства данного курорта». [там же стр. 16]

В 50-60-тых годах XX века в научной литературе публиковались разные исследования о Ахтале и гряземов вулкане. Интересные материалы содержатся в исследовании под названием «Грязевые вулканы (Ахтала) в Грузии», Тбилиси, 1978 г., изданном под авторством М. Дзвелая (Институт палеобиологии АН. Тбилиси, 1978 г.). В монографии рассматриваются роль, значение, происхождение, положение, состав и лечебныйэффект грязевых вулканов». [18] [М. Дзвелая, Грязевые вулканы в Грузии (Ахтала), Тбилиси, 1978 г.]

Монография Д. Джавахишвили и М. Меликишвили «Лечение грязью на курорте Ахтала» также касается роли и значения данного курорта. [18] [Тбилиси, 1955 г.] В нейподробно показаны характерные признаки лечения грязью, её лечебное действие на такие заболевания как: ревматизм, хронические инфекции, дистрофический артрит, травматический артрит, нарушение костно-мышечной системы, заболевания кровеносных сосудов, периферийной нервной системы, центральной нервной системы, кожные и гинекологические заболевания. Кроме выше сказанного, Ахтала обладает и такими лечебными факторамикак: санаторный режим, лечебное питание, физиотерапия, лечебные упражнения, массаж, аэротерапия, медикаментозное лечение. 
Таким образом, местному населению давно было известно о лечебных свойствах Ахталы. Больным грязевые процедуры проводились под открытым небом, вместе с солнечными ваннами. В настоящее время в Грузии, а именно в Кахетии одним из наилучших гелиотерапевтических ресурсов является курорт Ахтала.

На Ахтале курортный сезон начинается с апреля месяца. [Журнал «Аверси», 2014 г. №2, (108), стр. 52-53]. Сезон с момента открытия длится до конца ноября. «Грязь Ахталы используется в виде ванн и апликаций, имеется и электрическая грязь. Параллельно проводится лечебная физкультура, массаж, физиотерапевтические процедуры. Грязь используется при заболеваниях периферийной нервной системы, а именно радикулита, кроме того здесь лечат остаточные явления полиомиелита, парезы, послеожоговые рубцы, гинекологическиезаболевания, ревматизмы и т.д. Продолжительнось курса лечения 10-12 процедур. В обслуживание входят : грязевая процедура массаж,физиотерапия, ночлег и трёхразовое питание.http://www.ick.ge/rubrics/main-news/62-bnews/6799--r.htm

Статистические показатели за последние три года выглядят следующим образом: общее количество визитёров за 2014 год составляет 902 человека, за 2015 год - 889, за 2016 год - 762, с начала сезона 2017 года по сегодняшний день число составило 486. (Данные от 20 августа 2017 года).

Как видно из материалов, полученных от персонала Ахталы, в 2015 году количество визитёров уменьшилось, а в 2017 году здесь отдыхают из Баку, Казахстана, Средней Азии, Москвы и Израиля.Основную часть составляют азербайджанцы. Есть также версия превратить известный курорт Кахетии в спа-центр. Над концепцией развития Ахталы работает архитектурная компания Ирландии - «Аруп». Это одна из наиболее успешных проектных компаний мира, оперирующая в 37 странах. С генеральным директором и сопутствующими его лицами компании «Аруп» встретился министр инфраструктуры и регионального развития, на этой встрече было запланировано дальнейшее развитие данного курорта.

\section{Выводы:}

Таким образом, как видно из указанных выше архивных материалов и периодической прессы, интерес к курорту «Ахтала» возник уже более 100 лет назад, а находящийся здесь медицинский персонал имеет большие лечебные традиции и опыт. Исходя из этого, для дальнейшего развития курорта необходимо разработать долгосрочный стратегический план, в результате чего увеличится количество визитёров и недостатки будут устранены. Курорт нуждается в рекламе и показе всех его достоинств, нужно издать высокополиграфические брошюры, которые подробно расскажут о курорте. Считается целесообразным разрешить аренду курорта, в результате чего осуществиться развитие курортного хозяйства и вывоз минеральной воды и грязи за границу, всё это благоприятно скажется на развитии курорта, а также будет создано множество рабочих мест. Целесообразным считаю включать медицинские туристические туры в число туристических тур по Кахетии, при которых визитёры смогут познакомиться с уни- 
кальными возможностями и лечебно-оздоровительными ресурсами данного региона. Нужно также помнить, что в ареале Гурджаанского муниципалитета имеется множество достопримечательностей, а следовательно и визитёрам, находящимся на курорте можно предложить туристические маршруты культурно-познавательного характера. (Знакомство с такими музеями как: 1. Гурджаанский музей краеведения; 2. Дом-музей грузинской киноактрисы - Нато Вачнадзе; 3. Музейистории грузинской кавалерии им. Малхаза Шаликашвили; 4. Музей славы; 5. Музей сельской истории им. Георгия Маисурадзе; 6. Литературный музей им. Иосифа Нонешвили; 7. Музей известного физиолога Иване Бериташвили. Недалеко от курорта «Ахтала» имеется множество монастырей, самым старинным является монастырь VIIIвека «Квелацминда». Национальное агентство по защите культурного наследияприсвоило пяти церквям (построеным в V веке), находящимся в сёлах Гурджаанского муниципалитета, а именно в Калаури, Чалаубани, Вачнадзиани и Мукузани, статус недвижимого памятника культурного наследия.

2.С каждым днём растёт популярность велнес туризм, для его развития замечательным ресурсом является Ахтала, т.к. он богат прекрасным лесным массивом, положительно влияющим на настроение, психику и эмоции пациентов.

3. Для развития медицинского туризма на Ахтале нужно привести в порядок существуюшую инфраструктуру, снабдить здания современными технологиями. Если со стороны государства не будут выделены средства, курорт не сможет удовлетворять требования, и часть визитёров откажется от курорта несмотря на особенные лечебные свойства. К тому же, опираясь на современные медицинские требования, нужна переподготовка служебного персонала.

4. Медицинский туризм является источником быстрорастущего, популярного и прибыльного бизнеса во всём мире. Грузия со своей незабываемой природой, старинной культурой, традициями и обычаями ис огромным туристическим ресурсомоказалась в центре внимания туристов. Если осуществиться оснащение, существующих в Кахетии курортов, современными технологиями, то значительным образом возрастёт и число визитёров, что благоприятно отобразится как на бюджете региона, так и всей страны.

\section{References}

[1] Чинчарашвили И. Климатические ресурсы Кахетинского региона, Тбилиси, 2009 г.

[2] Хомерики Г. «Туризм», Тбилиси, 2008 г.;

[3] Журнал «Путешественник» Гиоргобистве № 11, 1901 г.;

[4] Журнал «Аверси», 2014 г.;

[5] Газета «Доктор», 1919 г.;

[6] Газета «Всадник» 1920 г.;

[7] «Наши достояния», том 5, стр. 213-214, Тбилиси, 2014 г., редактор Мзия Размадзе; 
[8] Грузинская Советская Энциклопедия, том 2, 1977 г., Тбилиси;

[9] Рекреационные курортно-туристические районы Грузии, стр. 122, Тбилиси, 2005 г.;

[10] М. Дзвелая, Грязевые вулканы (Ахтала) в Грузии, Тбилиси, 1978 г.;

[11] Иверия, 1886 г., 6 сентября № 192, стр. 2;

[12] Корганашвили Л., «Международный туризм» 2012 г., Тбилиси, 1978 г.;

[13] Национальный архив Грузии, исторический отдел, фонд 2003, опись 1, дело 7;

[14] Национальный архив Грузии, отдел новой и новейшей истории, фонд 1633 г., опись 4, дело 148, дело 280;

[15] http://www.ipress.ge/new/82063-gurjaanshi-khut-eklesias-kulturulimemkvidreobis-udzravi-dzeglis-statusi-mianicha В Гурджаани пяти церквям присвоен статус памятника недвижимого культурного наследия.

[16] http://travelingeorgia.ge/region/Resort-Arkhiloskalo/

[17] http://travelingeorgia.ge/region/Resort-Lagodekhi/ 


\title{
SURVEILLANCE OF IRRIGATION ASSOCIATIONS IN THE REPUBLIC OF BULGARIA - MANIFESTATION OF THE STATE POLICY IN THE IRRIGATION SECTOR
}

\section{Yordanov Velkovsky ${ }^{1}$}

\begin{abstract}
In the text of Art. 64, para. 1 of the Territorial Development Act [www.ciela.net] in the group of the elements of the technical infrastructure are included also the irrigation networks and their facilities and the irrigation works constructed to prevent the harmful impact of the waters. The hydrotechnical facilities, according to the text of Art. 137, para 1, item 1, are in the group of first category construction in the Republic of Bulgaria. Notwithstanding these important legal positions occupied by the hydrotechnical facilities, their exploitation in the field of irrigated agriculture in the Republic of Bulgaria is insufficient. Only one percent of the irrigated areas in the Republic of Bulgaria are irrigated [www.mzh.government.bg]. Until now in the Republic of Bulgaria there is no national inventory and register of dams and other hydro-technical sites with a meliorative character. The real irrigated areas are about 145 thousand hectares. As of 2001, the formation of Irrigation Associations in the Republic of Bulgaria started on the basis of legal regulations under a special law - Irrigation Association Act [www.ciela.net]. In these associations with specific legal texts an important role of the state is assigned to the Minister of Agriculture, Food and Forestry. For example, according to the wording of Art. 47, para. 1 of the Irrigation Association Act, the Minister of Agriculture, Food and Forestry has the legal opportunity to give the irrigation associations for 5 years right to use the sites of the irrigation infrastructure on the territory of the respective district where the state is the owner of the capital. Under other legal conditions, an irrigation association may also obtain a new right of use from the Minister of Agriculture, Food and Forestry for a period of 15 years. The Minister of Agriculture, Food and Forestry, according to the regulations of the Irrigation Associations Act, is the supervisor of these associations. This function corresponds to the need for active participation of the state in the irrigation and irrigation policies of the Republic of Bulgaria. The subject of the exhibition is the specific supervisory functions and their specifics, which the Minister of Agriculture, Food and Forestry exercises on the activity of the irrigation associations. The subject matter of the analysis is the legal regulations and accents on which the actions of the supervisor are based.
\end{abstract}

Keywords: Hydrotechnical facilities, Irrigation Associations Act, Minister of Agriculture, Food and Forestry, Irrigation Associations, Supervision,_Supervisor

\section{Legal characteristics of irrigation associations in the Republic of Bulgaria.}

\footnotetext{
1Valery Yordanov Velkovsky, Legal Advisor, Ministry of agriculture and food of the Republic of Bulgaria.
} 
The text of Article 2 (2) of the Irrigation Associations Act sets out the basic legal characterization of such a specific structure, such as an irrigation association. Each irrigation association has the legal status of a legal entity.

The Association obtains this legal status after having registered its registration in accordance with the approved legal procedure in the Irrigation Associations Act. Other specific legal characteristics of the associations in the Republic of Bulgaria are set out in the text of Article 2, paragraph 1 of the Law under review.

Who are they?

First, irrigation associations are voluntary organizations;

Secondly, they are organizations of individuals and legal entities;

Third, the activities that the association carries out are based on cooperation and mutual assistance in the public interest;

Fourthly, the activities of irrigation associations are related to irrigation-related measures, such as irrigation and drainage of agricultural land on the territory of the association.

In the text of Article 3 of the Irrigation Act, the activities for which irrigation associations in the Republic of Bulgaria can be formed are specified.

What are these activities?

First, associations are set up to operate maintenance and reconstruction of irrigation infrastructure;

Secondly, associations are set up to build new drainage systems and facilities;

Third, associations are set up to supply and distribute water for irrigation;

Fourthly, associations are set up to remove excess water from farmland;

Fifth, associations are created for the implementation of agro-meliorative and agrotechnical measures for improving the state of the agricultural lands;

Sixth, associations are created for fish breeding and breeding of waterfowl.

Outside of this legally regulated range, the irrigation association can not perform other activities as a legal entity registered under the terms of the Irrigation Association Act.

An important legal emphasis in the Irrigation Associations Act is the designation of a supervisor on the activities of irrigation associations in the Republic of Bulgaria.

Functions of the supervisory body on the activities of the irrigation associations in the Republic of Bulgaria.

In the text of Article 5, paragraph 1 of the Irrigation Associations Act, it is stated that irrigation associations are encouraged by the state.

The state has, as we have already mentioned, also supervisory functions over the activities of irrigation associations.

In this respect, according to the wording of Article 5, paragraph 2 of the Law under review, the functions of the Supervisory Body are assigned to the Minister of Agriculture, Food and Forestry of the Republic of Bulgaria.

What are the functions of the Supervisory Authority? 
According to the wording of Article 7 of the Law on Irrigation Associations, it is the supervising authority, by an order, to open a procedure for the establishment of an irrigation association.

This procedure is started under two conditions:

a / statement by a founding committee;

$\mathrm{b}$ / promulgated public order for initiating the procedure.

In the text of Article 9, Paragraph 4 of the Irrigation Associations Act, the legal capacity of the supervisory authority to refuse to open a procedure for the establishment of an irrigation association is regulated, in case of non-complied with the requirements of Article 9, paragraph 4.

These requirements are related to the subject matter, incorrect documentation, and so on.

Another function of the supervisory body, regulated by the Irrigation Associations Act, is the approval of changes to the association's articles of association.

In addition, the supervisory body, at the written request of the association, shall provide:

a / text information about the agricultural lands on the territory of the association, for the owners and users of these lands;

$\mathrm{b} /$ graphic and textual information about the irrigation infrastructure in the territory of the association, location, type, basic parameters and condition.

Another legal regulation, reflected in the text of Article 20, paragraph 1 of the Irrigation Act, is to establish and maintain a special register of irrigation associations in the Republic of Bulgaria.

The legal text of Article 21 of the Law on Irrigation Associations regulates the legal possibility for the supervisory authority to initiate an initiative for the voluntary establishment of an irrigation association.

To this end, there is a need for public interest in the effective use of water in compliance with environmental standards.

As a public resource, water should be used for the needs of agricultural structures that are located on the territory of the Irrigation Association.

The aim is to implement irrigation and drainage for the intensive use of agricultural land through the construction of irrigation infrastructure.

The possibilities that the texts of Chapter Seven of the Irrigation Associations Act provide for the transformation, termination and liquidation of irrigation associations are also legally related to the specific functions of the Supervisory Authority.

For example, the management board of an irrigation association is required to submit a request to the supervisory authority to approve the transformation within 14 days of holding a general assembly of the association.

Within 30 days, the supervisory authority shall communicate its decision.

The procedure for winding up an irrigation association shall start after the general meeting has taken its decision.

Simultaneously with the adoption of the decision to terminate the association, according to the wording of Article 64, paragraph 1 of the Irrigation Associations Act, the General Assembly appoints one or more liquidators. 
Liquidators must be approved by the supervisor and entered in the relevant registers.

Upon completion of the liquidation, the irrigation association as a legal entity shall be deleted from the register.

The deletion takes place after the submission of the documentation to the supervisory body's association.

The Authority is obliged to keep this documentation within 15 years.

Conclusion. Chapter eight of the Irrigation Associations Act summarizes the basic legal acronyms of the functions of the Supervisory Authority over the activity of irrigation associations - the Minister of Agriculture, Food and Forestry of the Republic of Bulgaria.

What are these highlights?

Firstly, the supervision exercised by the Minister of Agriculture, Food and Forestry of the Republic of Bulgaria on the activities of irrigation associations is:

- Legal;

- Financial;

- Technically.

In pursuance of its functions as supervisor, the Minister of Agriculture, Food and Forestry of the Republic of Bulgaria is assisted by administration and administrative apparatus.

Legal supervision includes:

a / approval of the association's articles of association and changes therein;

b) an order to the management board of the association to convene a general meeting when the activities of the association contradict the law;

c / convening a general meeting;

$\mathrm{d} /$ informing the members of the general meeting about the results of a check carried out on the activity of the association and compliance with the legal regulations;

e / removal of members of the Management Board in the case of their failure to fulfill their obligations;

f / convening a general meeting to elect a new board of directors.

Financial supervision includes:

a / appointment, if necessary, of audit control for annual review of the Association's accounting documents;

b / carry out a revision of the accounting documentation;

c / informing the members of the general meeting of the results of the relevant financial audit.

Technical supervision includes the following measures:

a / the right of access to technical information and documentation for the operation and maintenance of irrigation infrastructure;

b / conducting annual inspections of irrigation infrastructure and equipment and so on.

The Common Strategy for Management and Development of Irrigation and Water Pollution Prevention [www.mzhg.government.bg] has set several strategic objectives related to the participation of irrigation associations in the Republic of Bulgaria. 
For example, by the end of 2018, with the financial support of the European Agricultural Fund for Rural Development, the irrigation infrastructure managed by the irrigation associations in the Republic of Bulgaria should be restored and modernized and serve 2,500 hectares of irrigated area.

Legislative changes, including the Irrigation Act, are forthcoming and necessary in this respect.

References

[1] Irrigation Associations Act - prom. SG. issue 34 of 6 April 2001, amend. SG. issue 58 of July 18, 2017;

[2] Territorial Development Act - in force since 31.03.2001, SG. issue 1 of January 2, 2001, am. and sup. SG. No. 63 of August 4, 2017;

[3] www.mzh.government.bg;

[4] www.ciela.net 
RESEARCH ARTICLES.

For notes 


\section{B\&M Publishing}

Theoretical and practical issues of ensuring the economic interests of the modern innovative society. $3^{\text {rd }}$ edition: research articles, B\&M Publishing, San Francisco, California. 2017. 120 pp.

PQN 100

ISBN 978-1-941655-55-9 